Title page

Social bonding, gestural complexity and displacement behaviour of wild chimpanzee

Running head: Sociality and gestural complexity

Authors: Anna Ilona Roberts ${ }^{1}$ Sam George Bradley Roberts ${ }^{2}$

Affiliations:

${ }^{1}$ Department of Psychology, University of Chester, Chester; Parkgate Road, Chester CH1 4BJ, UK

${ }^{2}$ School of Natural Sciences and Psychology, Liverpool John Moores University, Byrom Street, Liverpool, L3 3AF

*Correspondence to: anna.roberts@chester.ac.uk, S.G.Roberts1@ljmu.ac.uk 


\section{Social bonding, gestural complexity and displacement behaviour of wild chimpanzee}

\section{Abstract}

2 Kinship and demography affect social affiliation in many different contexts such as co-feeding,

3 resting, travel, grooming, visual attention and proximity. Chimpanzees may coordinate these

4 social interactions by using gestural communication to make signaller's goal transparent to the

5 recipient and also by increasing commitment of the recipient through including rewarding

6 property in communication. The rewards of gesturing can be measured through the rates of

7 displacement behaviour made in response to these gestures by the recipient. We tested

8 hypothesis that gestural communication affects social affiliation after controlling for kinship and

9 demography in wild, adult chimpanzees living in Budongo Forest, Uganda. We found that

10 affiliative but not antagonistic gestures positively predicted social affiliation. Contexts differed in

11 their association with gestures according to complexity and association with displacement

12 behaviour. More complex, less intense gestures predicted mutual grooming, travel, visual

13 attention whereas less complex, more intense gestures predicted unidirectional grooming.

14 Mirroring these patterns, reduced displacement activity occurred in response to gestures

15 associated with unidirectional grooming but not other contexts. We highlight that these tactical

16 decisions that wild chimpanzees make in their use of gestural communication may be driven by

17 complexity of social environment that influences effectiveness with which signalers can influence

18 the recipient.

19 Keywords: social network, gestural communication, chimpanzee, joint action, resting, travel,

20 grooming, co-feeding, proximity, visual attention, complexity, function 


\section{Introduction}

Social bonds of animals, whereby particular dyads within the group preferentially

associate and affiliate with each other have fitness benefits by regulating within-group

competition in contexts such as feeding and mating. Such relationships have been found in

numerous animal species which include for instance, bottlenose dolphins (Tursiops aduncus)

30 (Möller, Beheregaray, Harcourt, \& Krützen, 2001), Bechstein's bats (Myotis bechsteinii) (Kerth,

31 Perony, \& Schweitzer, 2011), and sperm whales (Physeter macrocephalus) (Ortega-Ortiz,

32 Engelhaupt, Winsor, Mate, \& Rus Hoelzel, 2012). By far however, the most dynamic and stable

33 societies are those of primate species, and particularly great apes such as chimpanzees whereby

34 conspecifics regularly form social bonds manifest in many different contexts (F. B. M. De Waal,

35 1982; Goodall, 1986). Unsurprisingly perhaps, considerable research effort has been directed at

36 explaining the emergence and persistence of social bonds in primates (K. Langergraber, Mitani,

37 \& Vigilant, 2009; John C Mitani, Watts, Pepper, \& Merriwether, 2002; J. B. Silk, Seyfarth, \&

38 Cheney, 2018). At first, inclusive fitness behind social bonding with kin was ubiquitously claimed

to drive patterns of social bond formation (Hamilton, 1964). Although primates can and do

40 socially bond with kin (Wrangham, 1980), the principal role of kinship in driving primate

41 sociality has been discounted on the basis that in many socially complex primate species such as

42 gorillas, chimpanzees and the bonobos social bonding within dyads is not determined by kinship

43 (F. B. de Waal, 1986; John C Mitani et al., 2002; Watts, 1992). One another explanation that has

44 been provided for existence of social bonds in primates, is that demographic constraints such as

45 membership of the same age cohort can foster social bonding due to potency of peer influence

46 on one's behaviour and familiarity inherent in growing up in the same social context (Goldberg

47 \& Wrangham, 1997; Van Schaik \& Van Hooff, 1994). For those reasons, primates of same

48 reproductive status or sex, may also be found to have affiliative contact with each other at a

49 higher rate than among primates of different reproductive status or sex. For instance, male 
50 chimpanzees are more likely to groom with other males than the females (John C Mitani et al.,

51 2002). Thus, formation of social bonds in primates, often demands that some similarity between

52 interactants exists (Massen \& Koski, 2014). However, primate social groups are complex and

53 large, and primates often come into contact with conspecifics who are dissimilar and/or

54 unrelated. For these complex social groups of unrelated individuals to form and persist over

55 time, the social cohesion mechanism has to evolve that facilitates these social interactions. We

56 propose that gestural communication defined as voluntary movements of the hands, legs, head,

57 bodily postures or locomotory gaits (Hewes, 1973; Liebal, Call, \& Tomasello, 2004) is one

58 important mechanisms that facilitates formation of social bonds between individuals regardless

59 of similarity.

The gestural communication is highly variable across species but within species, there is

61 also a considerable variation that may facilitate choice of a social partner on the basis of several

62 gesture features. For instance, gestural communication can be multimodal and co-occur with

63 facial expressions or vocalisations, or it can be unimodal. Primates may incorporate objects such

64 as branch of a tree in signalling or the gesture may not contain use of objects. Gestures can be

65 combined with other gestural signals in a single utterance, or gesture may be produced singly (A.

66 I. Roberts, Vick, Roberts, Buchanan-Smith, \& Zuberbühler, 2012). The variation in gestural

67 communication may be associated with the degree of social bonding, because gestures vary in the

68 efficiency with which signaller can influence behaviour of the recipient (A. I. Roberts, Vick,

69 Roberts, \& Menzel, 2014). Signals of greater complexity that deviate from the population mean,

70 may be more effective at influencing the recipient, than the average signals (Dawkins \& Guilford,

71 1997; Zahavi \& Zahavi, 1997). There are however many different pathways to achieving a greater

72 efficiency in gestural communication. Studies in humans, showed that during perception of facial

73 expression accompanied by direct gaze and pointing, the amygdala processes emotional content

74 of communication. However, there is a concurrent integration of the directional communication

75 (pointing, gaze) in the premotor cortex that facilitates re-evaluation of prior expectations 
76 regarding perceived signaller's immediate intent from emotional expression alone (Conty,

77 Dezecache, Hugueville, \& Grèzes, 2012). Thus, pointing gestures with facial expressions have a

78 greater signal value than facial expressions alone and they can elicit a more accurate response

79 from the recipient. Recently studies documented similar behavioural strategies in primates (S.

80 Roberts \& A. I. Roberts, 2018). Chimpanzee females, for example, lower back to make infant

81 climb on it for travel as well as combining this bodily gesture with a manual sweep backwards in

82 direction of the infant, potentially using manual directional gesture to draw the attention of the

83 infant to the bodily gesture even though the infant is only a meter away and can respond to

84 bodily gesture alone. When initiating grooming, male chimpanzee may present the bodily part

85 that he wants to be groomed by the recipient, as well as making almost imperceptible sound to

86 an observer standing only a short distance away, but clearly of fundamental importance to the

87 recipient.

88 The social relationships of primates, however, may not always be guided by selection for

89 effectiveness of communication (Dawkins \& Guilford, 1997). If both interactants have mutual

90 interest in signalling and responding then the recipient may become sensitive to the signaller,

91 whereas signaller may make communication less complex. These scenarios are evolutionarily

92 stable because the communication is effective at achieving its desired goal, whilst reducing the

93 costs of potential harassment by third party or predators in circumstances when the signal is

94 conspicuous and large. An example would be left handed gesture seen in a common goal

95 contexts signifying stronger social bonding (e.g. mutual grooming, joint travel, mutual visual

96 monitoring) versus right handed gestures seen in contexts whereby interactants do not have a

97 common goal signifying weaker social bonding (e.g. unidirectional grooming, lack of mutual

98 visual monitoring) (Noë, 2006). Studies have recently emphasized how low intensity of

99 communication is important for fitness by reducing stress inherent in social interaction

100 (Nakayama, Goto, Kuraoka, \& Nakamura, 2005; A. I. Roberts \& S. G. B. Roberts, 2016). When

101 individuals who are less strongly bonded interact, there may be a greater conflict of interest and 
102 therefore low intensity communication may be ineffective at influencing behavioural change in

103 the recipient (Dawkins \& Guilford, 1997). There is a wealth of studies that describe the

104 phenomena whereby recipients respond more strongly to visual communication that is complex

105 than to visual communication that is non-complex. Possibly, the most well-known are the

106 elaborations and repetitions of visual signals seen in mating contexts. For instance, male frogs

107 incorporating a higher rate of action repetition in visual display are more likely to attract female

108 for mating than the males incorporating lower rate of action repetition in the visual display

109 (PAYNE \& PAGEL, 1997).

Complex visual signals as effective means of signalling, however, may reach a limit at

which further increasing of complexity will not have any bearing on effectiveness of interaction

112 with the recipient. Another way, in which signallers can influence efficiency of their signalling is

113 by stimulating the reward system of the recipient. By making a gesture rewarding, signaller

114 enhances recipient's commitment to the interaction, thereby making these social relationships

115 possible. Such circumstances, for instance, may be present in complex social settings, whereby

116 presence of other conspecifics in vicinity, provides competitive background against which

117 signaller competes for attention of the recipient. By increasing their rewarding value, signals

become more pleasurous to the receivers and to that extent become more capable of evoking a

response from the recipient. During grooming, chimpanzees sometimes direct visual gestures to

make the recipient present body for grooming, but when recipient is unresponsive they switch to

121 gentle, but more intense tactile gestures to achieve their goal (A. I. Roberts, Vick, \& Buchanan-

122 Smith, 2013). Higher intensity signals are more perceivable by the receivers and by virtue of

123 being more intense can exert greater influence on the recipient (Zahavi \& Zahavi, 1997).

124 Subordinate male chimpanzees for instance, use visual gestures designed to attract female for

125 mating in absence of visual attention from the dominant male, but these gestures become intense

126 and loud when the female is unresponsive because the dominant male is watching the interaction

127 (A. I. Roberts \& Roberts, 2015). High intensity however, can reduce or even reverse the 
128 preference for signals that are based on complexity of structure hence high intensity signals can

129 become less complex (Gerhardt \& Doherty, 1988). For instance, chimpanzee visual gestures are 130 often accompanied by high complexity such as use of mutual attention, low intensity call or 131 synchronized call in contrast to tactile and auditory gestures that are less often accompanied by 132 these characteristics (S. Roberts \& A. I. Roberts, 2018).

Final issue of importance for establishing which communication characteristics can influence preference for social affiliation is the positive versus negative communication style. Maestripieri and colleagues $(1999,2005)$ were amongst the first to recognize that affiliative as opposed to antagonistic gestural communication was of profound importance to the likelihood 137 of social affiliation. Comparing three species of macaques with different social styles, they were 138 able to show that more tolerant macaque species where the influence of kinship on social 139 relationships was reduced displayed a larger repertoire of affiliative communication when 140 compared to less tolerant macaque species where the influence of kinship was stronger. In more 141 tolerant macaque species social interactions can easily disintegrate in response to exposure to aggression demanding higher investment in repair through affiliative communication. More recently, a study of a wild chimpanzee group showed that higher rates of affiliative gestural communication relative to antagonistic gestural communication predict a longer duration of time spent in proximity (S. G. B. Roberts \& A. I. Roberts, 2016). communication affects primate social affiliation. Chimpanzees, live in large, fission-fusion social

148 groups of up to 120 individuals, associating and affiliating in subgroups of varying duration and 149 composition (Goodall, 1986). Due to fission-fusion nature of social system, mother and maternal 150 kin are often unavailable as social partners demanding that chimpanzees form social bonds with 151 unrelated group members (Goldberg \& Wrangham, 1997; John C Mitani et al., 2002). The 152 chimpanzees derive fitness benefits of social affiliation with unrelated group members in many 
153 different contexts such as grooming, coalitions, sharing meat, and hunting (Boesch, 1996;

154 Foerster et al., 2015; Goldberg \& Wrangham, 1997; K. E. Langergraber, Mitani, \& Vigilant,

155 2007). Recent research has generated proofs that gestural communication of chimpanzees can

156 influence preference for social affiliation. For example, recent studies have demonstrated the link

157 between proximity measures (an index of sociality) and a number of different indices of

158 communicative complexity such as intentionality (A. I. Roberts, 2018; A. I. Roberts \& S. G. B.

159 Roberts, 2018), repertoire size (A. I. Roberts, Chakrabarti, \& Roberts, 2019) and multimodality

160 (S. Roberts \& A. I. Roberts, 2018). Whereas the role of gestures in maintaining proximity has

161 been made clear, the role of gestural communication has received only limited research attention

162 with regard to its influence on any other aspect of social affiliation in primates. However, in

163 order to develop a deeper understanding of the factors driving social relationships, several

164 measures of the social complexity are needed. As well as proximity, primates use visual attention

165 to monitor conspecifics and also preferentially associate with others during grooming, feeding,

166 resting and travel (Nishida, Zamma, Matsusaka, Inaba, \& McGrew, 2010). All these different

167 modes of interaction contribute to forming social relationships (Hinde, 1976). Studies which only

168 focus on one behavioural aspect may therefore miss important features of social relationships.

169 Here we provide first systematic test of the hypothesis that gestural communication can

170 influence preference of the recipient to form social relationships with the signaller. First, to test

171 this hypothesis we use social network analysis to determine the link between communication and

172 social bonding behaviours. Social network analysis represents individuals as nodes (e.g. individual

173 A or B) and the social relationships (e.g. duration of time spent travelling, per hour spent within

$17410 \mathrm{~m}$ between $\mathrm{AB}$ dyad) as the edge or a 'tie'. Social network analysis examines how increase in

175 the value of one variable produced by a dyad is associated with the increase or decrease in the

176 value of another variable by a dyad (Croft, James, \& Krause, 2010). For instance, if individual A

177 directs tactile gestures and grooming at the individual B, then social network analysis can

178 determine whether the rate of tactile gestures directed by individual $A$ at the individual $B$ is 
179 associated with increase or decrease in the duration of time individual A spends grooming 180 individual B.

181 It has long been established that animal signals evolve to function effectively in a 182 particular social environment. The variation in the conflict of interest between signaler and the 183 recipient is reflected in how effectively different types of gesturing can influence social bonding.

184 When social bonds are weaker, and the conflict of interest between signaler and the recipient is 185 high, chimpanzees use more effective, and intense gestures (e.g. tactile, auditory). In contrast, 186 when the social bonds are stronger and the conflict of interest is low, chimpanzees use less 187 effective and less intense gestures (e.g. visual). However, intensity of gestures affects the 188 specificity with which signaller can convey their goal of the interaction. Low intensity, visual 189 gestures are less specific to context than more intense tactile or auditory gestures. Lack of 190 specificity may affect the recipient's ability to effectively decode signal meaning and thus respond 191 adaptively. One would therefore predict that communicative complexity would more likely co192 occur with less intense gestures (e.g. visual) than with more intense gestures to enable the 193 signaller to increase specificity of the gestures so that the recipient can decode signal meaning. 194 Thus, one may predict that low intensity, complex signals will co-occur with indices of stronger 195 social bonding (e.g. mutual grooming, joint travel), whereas higher intensity, non-complex signals 196 will co-occur with indices of weaker social bonding (e.g. unidirectional grooming). In addition, it 197 seems reasonable to assume that style of the gestural communication will affect the efficiency 198 with which individuals can form social relationships. For instance, more bonded partners may 199 exhibit a higher rate of gestures used in affiliation contexts as compared with antagonistic 200 contexts because signaller gestures affiliatively to increase duration of social bonding. However, 201 to date, this association between social relationships and complexity of gestural communication 202 has not been examined systematically. 
203 Second, we determine whether displacement behaviours such as self-scratching that help

204 primates cope with anxiety (Aureli \& Schaik, 1991; Baker \& Aureli, 1997; Castles \& Whiten,

205 1998; Diezinger \& Anderson, 1986; Schino, Perretta, Taglioni, Monaco, \& Troisi, 1996) are

206 associated with gestural communication that facilitates social bonding. Studies of long-tailed

207 macaques (Aureli \& Schaik, 1991), olive baboons (Castles \& Whiten, 1998) and chimpanzees

208 (Baker \& Aureli, 1997) have all used scratching to reliably estimate primate's level of anxiety.

209 Chimpanzees may experience increased anxiety in situations of social uncertainty linked to

210 presence of unpredictable social partners with whom social interactions are infrequent or

211 dominance relationships have been unresolved (Aureli, 1997; Schino, Scucchi, Maestripieri, \&

212 Turillazzi, 1988). In this case, one may predict that communication aimed at these social partners

213 may be associated with higher rate of signaller's displacement activity. Furthermore, chimpanzees

214 may experience reduced anxiety in response to communication that has a rewarding property.

215 For instance, vocal communication can prompt a surge in the production of social

216 neurohormones in the recipient, such as a surge of oxytocin that relieves anxiety (Feldman,

217 Gordon, \& Zagoory-Sharon, 2011). In this case, it would be predicted that communication

218 associated with weaker social bonds would be associated with reduced rate of displacement

219 activity in the recipient.

\section{Methods}

Twelve adult East African chimpanzees (Pan troglodytes schweinfurthii) (6 males and 6

222 females) were observed for a mean (SD) duration of 751.5 (250.9) min per each focal individual

223 (Table 1). The sample included almost all of the uninjured adult males in the community and to

224 match the sample size of the males, a similar number of uninjured females was chosen as focal

225 individuals. The subjects were chosen on the basis that they were lacking physical injury, because

226 the injuries such as deformation of the hand by the snare can influence the type of

227 communication used. Moreover, the sample of males and females was matched as closely as 
228 possible in terms of rank categories, including three low ranking and three high ranking males 229 and females).

230 The chimpanzees lived in the tropical forest, Sonso community at the Budongo 231 Conservation Field Station in Uganda, East Africa. The data was collected during 18 minute 232 focal animal follows, consisting of 9 scans at 2 minute intervals, recording the activity of the 233 focal individual (grooming, travel, resting, feeding), the visual attention, activity and proximity of 234 the nearest neighbor and the identity of all individuals present within $10 \mathrm{~m}$ (see Table 2 for 235 definitions). Chimpanzees in the wild, especially when present in large parties, can change 236 behavior and activity frequently. Thus, in order to reduce variability within samples, a focal 237 follow of 18 minute duration was chosen. Gestures were recorded continuously using a digital 238 video camera, verbally recording directly onto the footage the identity and the behavior of the 239 signaler and recipient, along with the goal directedness in the behavior and the functional 240 context.

241 Using the video footage, the inventory identified gestures as acts of non-verbal behavior 242 that were expressive movements of the limbs, head or the body posture that were intentional, 243 communicative and mechanically ineffective. The detailed description of intentionality coding, 244 along with the video clips of each gesture type, has been described previously (A. I. Roberts, 245 Roberts, \& Vick, 2014; A. I. Roberts, Vick, \& Buchanan-Smith, 2012; A.I. Roberts et al., 2012).

246 Validation of the coding procedure was established by a second coder and reliability (Kappa 247 coefficient, $K)$ was good for function $(K=0.70)$, modality of gesturing $(K=0.946)$ and 248 intentionality $(\mathrm{K}=0.74)$ (S. G. B. Roberts \& A. I. Roberts, 2016). The behavioural measures 249 (e.g. joint feeding, mutual grooming) were calculated as the duration of time pairs of 250 chimpanzees engaged in these behaviors, per hour they spent within $10 \mathrm{~m}$. The definitions as 251 well as mean \pm SD for all variables entered into the models can be found in Tables 2 and 3. 252 Dyads were classified according to maternal kinship, sex, age class and reproductive state. All 
253 communication measures were calculated as a rate per hour chimpanzees spent within $10 \mathrm{~m}$ (see

254 Supplementary Table 1 for definitions).

255 The rates of communication and durations of behavior were used to construct weighted,

256 directed networks. The data was transformed and analyzed using UCINET 6 for Windows

257 (Borgatti, Everett, \& Johnson, 2013). The data used in social network matrices is dependent and

258 therefore analysis using randomization (or permutation) have been developed, where the

259 observed value is compared against a distribution of values generated by a large number of

260 random permutations of the networks. The $p$ value is calculated by calculating the proportion of

261 random permutations in which a value as large (or as small) as the one observed is present. The

262 relationships between networks were analyzed using Multiple Regression Quadratic Assignment

263 Procedure (MRQAP) (Borgatti et al., 2013). This regression technique resembles a standard

264 regression model as it enables us to examine the association between a number of predictor

265 variables (e.g. rates of gestural communication between dyads, control variables relating to sex

266 and age differences of dyads) and a single dependent variable (e.g. duration of proximity between

267 dyads). We used Double Dekker Semi Partialling MRQAP regression as it is more robust against

268 the effects of network autocorrelation and skewness in the dataset than other forms of network

269 regression (Dekker, Krackhardt, \& Snijders, 2007). For this analysis, 2,000 permutations were

270 used following the settings of UCINET.

Running large numbers of models risks inflating significance levels (Field, 2013). To

272 address this issue, following the methods used by Pearce et al. (2017), we examined whether the

273 overall distribution of significant results varied across the different domains of sociality (joint

274 activity, grooming, visual attention, proximity and scratch) and behavioural categories. These

275 data are not subject to potential problems arising from multiple comparisons effects because the

$276 \mathrm{p}$ value is used to categorise the results in each category as statistically significant or not, and one

277 chi-square test is then carried out on the overall distribution of results (Pearce et al., 2017). Thus, 
278 we used a Chi-square test to examine the overall pattern of association between the behavioral

279 indices and gestural communication. Following the same method as Pearce et al. (2017), this

280 allowed us to examine whether the significant associations between gestural communication and

281 behavior showed a distinct pattern, with certain types of gestural communication associated with

282 specific behavioral indices more commonly than would be expected, as compared to a random

283 distribution. This method is used as an alternative to Bonferroni correction when the multiple

284 comparisons prevent the Bonferroni correction being used (M. J. Silk, Jackson, Croft, Colhoun,

285 \& Bearhop, 2015). We created contingency table whereby we included percentage of significant

286 associations $(\mathrm{p}<0.05)$ with each variable within each domain of social complexity

287 (Supplementary Table 2). The results showed that the distribution of significant associations was

288 non-random $\left(\chi^{2}=364.90, \mathrm{df}=60, \mathrm{p}<0.001\right)$. This demonstrated that the significant results

289 were not randomly distributed across the different domains of sociality, suggesting that different

290 types of gestural communication are differentially associated with the types of sociality. In all

291 tests, two-tailed probabilities were used, with $\mathrm{p}$ set at $<0.05$. Supplementary Information 2 gives

292 a summary of these findings, with the full models provided in Supplementary Information 1

293 (Tables S3 - S19).

294 Results

295 Based on our 12 focal subjects, we studied directed patterns of social behaviour in pairs

296 of chimpanzees, giving 132 unique dyadic relationships (e.g. the duration of grooming given by

$297 \mathrm{BB}$ to HW, and the duration of grooming given by HW to BB). There was a great deal of

298 variation in the rate of social behaviours amongst the dyads and across the different behaviours,

299 as indicated by the fact that for all of the behaviours the standard deviation was larger than the

300 mean (Table 2). Per hour spent within $10 \mathrm{~m}$, the mean \pm SD number of minutes dyads spent in

301 social behaviours ranged between $0.44 \pm 1.58$ spent in joint travel and $6.16 \pm 10.05$ spent in close

302 proximity (within $2 \mathrm{~m}$ ). Dyads scratched at a mean rate $\pm \mathrm{SD}$ of $0.64 \pm 1.68$ instances of 
303 scratching, per hour spent within $10 \mathrm{~m}$. Similarly for the communication indices, there was a

304 large amount of variation between dyads, with lowest mean \pm SD rate of behaviour for gestures

305 accompanied by facial expression $(0.09 \pm 0.52)$ and the highest mean \pm SD rate of events $(3.18$

$306 \pm 7.82)$ - Supplementary Table 2.

307

308

\section{Association between the duration of social behaviour and gestural communication categorized according to structure}

In the next set of analyses, we used MRQAP network regression analyses to examine how the duration of social behaviours (the dependent variable in all the models) was associated with the rate of different types of gestural communication and demography (see Figures 1 and 2 for visual representation of the networks).

\section{Joint feeding}

Same sex dyads $(\beta=0.31, p=0.001)$, kin $(\beta=0.29, p=0.010)$ and same reproductive status $(\beta$ $=0.22, p=0.040)$ dyads spent a significantly longer amount of time engaged in joint feeding, as compared to different sex dyads, unrelated dyads or different reproductive status dyads. Dyads who spent a longer amount of time jointly feeding had a significantly higher rate of auditory short-range gestures $(\beta=0.21, p=0.040)$ and significantly lower rate of tactile gestural communication $(\beta=-0.22, p=0.004)$.

Joint resting

Same age dyads, as compared to different age dyads, spent a significantly longer amount of time engaged in joint resting $(\beta=0.29, p=0.003)$. There was a positive association between the duration of time spent in joint resting and the rate of auditory short-range $(\beta=0.13, p=0.040)$ and close proximity $(\beta=0.12, p=0.046)$ gestures.

\section{Joint travel}


326 Same-age dyads, as compared to different-age dyads, spent a significantly longer amount of time

327 jointly travelling $(\beta=0.28, p=0.010)$. Further, the duration of joint travel was positively

328 associated with a higher rate of gestural communication without objects $(\beta=0.47, p=0.005)$,

329 visual $(\beta=0.62, p=0.010)$, unimodal $(\beta=0.22, p=0.020)$ and multimodal with facial

330 expression $(\beta=0.30, p=0.020)$, combined $(\beta=0.41, p=0.004)$, accompanied by mutual

331 attention present $(\beta=0.37, p=0.010)$, bodily $(\beta=0.50, p=0.003)$, manual indicative $(\beta=0.42$,

$332 p=0.011)$, close $(\beta=0.27, p=0.015)$ and far $(\beta=0.22, p=0.013)$, non-repetitive $(\beta=0.55, p=$

333 0.006), homogeneous $(\beta=0.43, p=0.010)$, single (no sequence) $(\beta=0.22, p=0.026)$, rapid $(\beta=$

$3340.20, p=0.020)$ and persistence sequence $(\beta=0.14, p=0.045)$, and accompanied by piloerection

$335(\beta=0.38, p=0.006)$, The repertoire size of gesture types $(\beta=0.34, p=0.010)$ and number of 336 events exchanged by each dyad $(\beta=0.39, p=0.003)$ was positively associated with the duration

337 of joint travel. In contrast, a higher rate of auditory long-range gestures was associated with 338 shorter durations of time spent in joint travel $(\beta=-0.28, p=0.010)$.

Same-age dyads spent significantly longer engaged in giving grooming $(\beta=0.21, p=0.020)$. The duration of time spent giving grooming was positively associated with a higher rate of production of following categories of gestural communication: no object $(\beta=0.64, p=0.001$, auditory short-range $(\beta=0.73, p=0.001)$, auditory long-range $(\beta=0.19, p=0.010)$, tactile $(\beta=$ $0.41, p=0.001)$, unimodal $(\beta=0.75, p=0.001)$, dyadic repertoire size $(\beta=0.26, p=0.020)$, single (non-combined) $(\beta=0.64, p=0.001)$, mutual attention absent $(\beta=0.78, p=0.001)$, bodily $(\beta=0.22, p=0.023)$, manual $(\beta=0.29, p=0.016)$, events $(\beta=0.46, p=0.002)$, manual indicative $(\beta=0.17, p=0.036)$, manual non-indicative $(\beta=0.35, p=0.014)$, close $(\beta=0.76, p=$ 0.001 ), repetitive $(\beta=0.60, p=0.001)$, homogenous $(\beta=0.52, p=0.004$ ) and single (no sequence) $(\beta=0.66, p=0.001)$. In contrast, the dyads who spent a shorter duration of time giving grooming communicated at a higher rate through the use of objects $(\beta=-0.20, p=0.010)$, 
351 visual gesture $(\beta=-0.26, p=0.010)$, multimodal (facial expression) $(\beta=-0.23, p=0.010)$,

352 combined $(\beta=-0.19, p=0.020)$, mutual attention present $(\beta=-0.11, p=0.040)$ and far $(\beta=-$

$3530.11, p=0.012)$.

Grooming mutual

355 Same age dyad partners spent a longer duration of time mutually grooming $(\beta=0.20, p=0.049)$.

356 A longer duration of time spent mutually grooming was also associated with a higher rate of the 357 following gesture types: no object $(\beta=0.64, p<0.001)$, visual $(\beta=0.88, p<0.001)$, unimodal $(\beta$ $358=0.27, p=0.020)$, multimodal (facial expression) $(\beta=0.44, p=0.002)$, dyadic repertoire size $(\beta$ $359=0.45, p=0.003)$, combined $(\beta=0.40, p=0.003)$, mutual attention present $(\beta=0.63, p=$ $3600.001)$, bodily $(\beta=0.58, p=0.001)$, events $(\beta=0.45, p=0.003)$, manual indicative $(\beta=0.56, p=$ $3610.001)$, non-repetitive $(\beta=0.72, p=0.001)$, homogeneous $(\beta=0.60, p<0.001)$, close $(\beta=0.38$, $p=0.004)$, far $(\beta=0.22, p=0.018)$, single (no sequence) $(\beta=0.33, p=0.012)$, rapid $(\beta=0.16, p$ $=0.041)$ and persistence sequence $(\beta=0.16, p=0.030)$ and piloerection $(\beta=0.42, p=0.004)$.. In contrast, a higher rate of gestures object $(\beta=-0.15, p=0.020)$, auditory long range $(\beta=-0.51$, $p<0.001)$, repetitive $(\beta=-0.18, p=0.004)$ and heterogeneous $(\beta=-0.15, p=0.016)$ predicted a shorter duration of time spent mutually grooming.

Same-sex dyads, compared to different-sex dyads, spent a significantly longer amount of time receiving grooming $(\beta=0.20, p=0.030)$. Individuals who received a longer duration of grooming from the dyad partners produced gestures with no object $(\beta=0.22, p=0.040)$, visual $(\beta=0.50, p=0.020)$, unimodal $(\beta=0.25, p=0.040)$, bodily $(\beta=0.25, p=0.036)$, manual indicative $(\beta=0.17, p=0.046)$, non-repetitive $(\beta=0.20, p=0.035)$ and homogeneous $(\beta=0.17$, $p=0.048)$ at a higher rate. However, individuals who received a shorter duration of grooming

374 from the dyad partner directed auditory long range $(\beta=-0.27, p=0.020)$ and tactile $(\beta=-0.20, p$ $<0.001)$ gestures at them at a higher rate. 
377 Presence of mutual attention occurred between dyads of same-sex $(\beta=0.30, p=0.010)$ and 378 same reproductive status $(\beta=0.28, p=0.040)$ at a higher rate. Individuals who spent longer 379 duration of time mutually attending with the dyad partner displayed a significantly higher rate of 380 gestures with no object $(\beta=0.69, p<0.001)$, visual $(\beta=0.75, p<0.001)$, auditory short-range $(\beta$ $381=0.24, p=0.010)$, unimodal $(\beta=0.44, p<0.001)$, multimodal (facial expression) $(\beta=0.31, p=$ $0.003)$, dyadic repertoire size $(\beta=0.42, p=0.002)$, single (non-combined) $(\beta=0.29, p=0.004)$, combined $(\beta=0.30, p=0.002)$, mutual attention present $(\beta=0.56, p<0.001)$, bodily $(\beta=0.54$, $p=0.001)$, events $(\beta=0.47, p=0.001)$, manual indicative $(\beta=0.54, p=0.001)$, close $(\beta=0.50$, $p=0.001)$, far $(\beta=0.13, p=0.045)$, non-repetitive $(\beta=0.56, p=0.004)$, homogeneous $(\beta=$

$0.60, p=0.001)$, single (no sequence) $(\beta=0.47, p=0.001)$ and piloerection $(\beta=0.35, p=0.005)$.

In contrast, individuals who spent a shorter duration of time mutually attending with the dyad partner displayed a significantly higher rate of gestures with object $(\beta=-0.18, p=0.003)$, auditory long-range $(\beta=-0.44, p<0.001)$, multimodal (vocal) $(\beta=-0.09, p<0.049)$ and heterogeneous $(\beta=-0.09, p=0.046)$.

Same-aged dyad partners spent a longer duration of time mutually non-attending towards one another as compared to different age partners $(\beta=0.36, p=0.001)$. The duration of time dyad partners spent mutually non-attending was positively associated with the rates of gestures with no object $(\beta=0.24, p=0.028)$, auditory short-range $(\beta=0.29, p=0.011)$, unimodal $(\beta=0.27, p$

$396=0.024)$, single (non-combined) $(\beta=0.18, p=0.045)$, mutual attention absent $(\beta=0.28, p=$ $3970.015)$, events $(\beta=0.15, p=0.049)$, close $(\beta=0.28, p=0.021)$, single (no sequence) $(\beta=0.23, p$ $398=0.026)$ and homogeneous $(\beta=0.17, p=0.043)$. 
400 In comparison with different-age dyad partners, same-age dyad partners $(\beta=0.32, p<0.001)$

401 spent a significantly longer duration of time in close proximity (within $2 \mathrm{~m}$ ). There was a significant positive association between the duration of time spent in close proximity and a higher rate of a wide range of communication: no object $(\beta=0.56, p<0.001)$, visual $(\beta=0.45, p$

$404=0.010)$, auditory short-range $(\beta=0.34, p=0.010)$, unimodal $(\beta=0.44, p=0.001)$, multimodal 405 (facial expression) $(\beta=0.14, p=0.049)$, dyadic repertoire size $(\beta=0.28, p=0.010)$, combined $(\beta$ $406=0.29, p=0.010)$, mutual attention absent $(\beta=0.26, p=0.010)$, mutual attention present $(\beta=$ $0.30, p=0.010)$, bodily $(\beta=0.40, p=0.003)$, events $(\beta=0.37, p=0.003)$, manual indicative $(\beta=$ $0.37, p=0.007)$, close $(\beta=0.48, p=0.001)$, non-repetitive $(\beta=0.33, p=0.012)$, homogeneous $(\beta=0.45, p<0.001)$, single (no sequence) $(\beta=0.42, p<0.001)$ and piloerection $(\beta=0.21, p=$ 0.027). In contrast, there was a significant negative association between the duration of time

411 spent in close proximity and the rate of gestures using object $(\beta=0.17, p=0.003)$, auditory

412 long-range $(\beta=-0.27, p=0.010)$ and multimodal (vocal) $(\beta=-0.11, p=0.040)$.

\section{Scratch produced}

414 We further examined how the rate of scratch produced was related to the rates of 415 communication using MRQAP (Fig. 1). Same-sex dyad partners had a higher rate of scratch 416 produced than different-sex dyad partners $(\beta=0.20, p=0.039)$. A higher rates of scratch 417 produced were positively associated with higher rates of the following types of gestures: no 418 object $(\beta=0.40, p=0.004)$, visual $(\beta=0.48, p=0.008)$, unimodal $(\beta=0.18, p=0.049)$, 419 multimodal (facial expression) $(\beta=0.18, p=0.042)$, dyadic repertoire size $(\beta=0.35, p=0.002)$, 420 single (non-combined) $(\beta=0.25, p=0.016)$, mutual attention present $(\beta=0.52, p=0.001)$,

421 bodily $(\beta=0.54, p<0.001)$, events $(\beta=0.36, p=0.003)$, manual indicative $(\beta=0.40, p=0.003)$,

422 close $(\beta=0.21, p=0.023)$, far $(\beta=0.24, p=0.001)$, non-repetitive $(\beta=0.41, p=0.004)$,

423 homogeneous $(\beta=0.37, p=0.002)$, persistence $(\beta=0.57, p<0.001)$ and piloerection $(\beta=0.23$, $424 p=0.022$ ). There was a significant negative association between rates of scratch produced and 
425 the rates of auditory long-range $(\beta=-0.16, p=0.046)$ and manual $(\beta=-0.18, p=0.011)$

426 gestures.

427 Scratch received

428 Same-sex dyad partners had a higher rate of scratch received than different-sex dyad partners $(\beta$

$429=0.20, p=0.043)$. There was a significant negative association between rate of scratch received

430 and the rate of auditory short-range gestures $(\beta=-0.010, p=0.049)$, gestures accompanied by

431 mutual attention absent $(\beta=-0.13, p=0.049)$, close proximity $(\beta=-0.11, p=0.048)$, repetitive

$432(\beta=-0.44, p=0.044)$ and single (no sequence) $(\beta=-0.14, p=0.044)$ gestures.

433 Association between the duration of social behaviour and gestural communication 434 categorized according to function

435 We examined whether the duration of social behaviours (the dependent variable in all the 436 models) was associated with the rate of different types of gestural communication categorized 437 according to function. Chimpanzee dyads that produced higher rates of gesture threat to 438 dominate spent a shorter duration of time jointly feeding $(\beta=-0.50, p=0.045)$, mutually 439 grooming $(\beta=-0.65, p=0.006)$ and visually attending to each other $(\beta=-0.64, p=0.004)$.

440 Gestures to give groom predicted a longer duration of time spent in jointly feeding $(\beta=0.17, p$

$441=0.039)$, giving grooming $(\beta=0.69, p<0.001)$, attention present $(\beta=0.25, p=0.011)$ and 442 absent $(\beta=0.24, p=0.019)$, proximity $(\beta=0.30, p=0.007)$. Further gestures to give groom 443 elicited significantly lower rates of scratch received $(\beta=-0.15, p=0.020)$. Chimpanzee dyads 444 that had higher rates of gestures in the context of mutual grooming spent a longer duration of time in mutual grooming $(\beta=1.14, p=0.010)$ and visually attending to each other $(\beta=0.79, p=$

446 0.025). Gestures to receive grooming were positively associated with the duration of time spent 447 jointly feeding $(\beta=0.47, p=0.012)$, giving grooming $(\beta=0.20, p=0.036)$, mutual grooming $(\beta$ $448=0.53, p=0.008)$, receiving grooming $(\beta=0.90, p=0.001)$, attention present $(\beta=0.51, p=$ $4490.001)$ and absent $(\beta=0.38, p=0.022)$ and proximity $(\beta=0.55, p=0.006)$. Higher rate of other 
450 threat gestures was negatively associated with a longer duration of time spent giving grooming $(\beta$

$451=-0.06, p=0.029)$ and were positively associated with a higher rate of scratch produced $(\beta=$

$4520.48, p=0.002$ ). Synchronized high-intensity panthoot was negatively associated with attention

453 absent $(\beta=-0.09, p=0.049)$, proximity $(\beta=-0.10, p=0.012)$ and scratch received $(\beta=-0.13, p$

$454=0.019)$. Synchronized low-intensity panthoot was positively associated with joint feeding $(\beta=$

$4550.14, p=0.043)$, travel $(\beta=0.26, p=0.012)$, attention present $(\beta=0.10, p=0.048)$ and absent

$456(\beta=0.13, p=0.035)$ and proximity $(\beta=0.14, p=0.023)$. A higher rates of play gestures were

457 positively associated with the duration of give grooming $(\beta=0.10, p=0.010)$ and negatively

458 associated with the duration of time spent jointly feeding $(\beta=0.19, p=0.004)$, mutual $(\beta=$ -

$4590.10, p=0.012)$ and received grooming $(\beta=-0.20, p=0.002)$, attention present $(\beta=-0.09, p=$

$4600.017)$ and proximity $(\beta=-0.08, p=0.046)$. Higher rates of greeting gestures were associated

461 with a longer duration of time spent giving grooming $(\beta=0.11, p=0.025)$ and a shorter

462 duration of time spent receiving grooming $(\beta=-0.08, p=0.041)$. Finally, higher rates of travel

463 gestures were positively associated with a longer duration of time spent giving grooming $(\beta=$

$4640.10, p=0.034)$ and travel $(\beta=0.10, p=0.048)$.

\section{Discussion}

Most studies of chimpanzee social relationships in the wild or in captivity focus on one aspect of relationships, such as proximity (A. I. Roberts \& S. G. B. Roberts, 2016; A. I. Roberts \& Roberts, 2017; S. G. B. Roberts \& A. I. Roberts, 2016). Here we provide first systematic evidence that chimpanzees form social relationships across many different contexts more 470 effectively with those individuals with whom they communicate through gestural 471 communication.

472 Previous research on male chimpanzees suggested that maternal kinship did not play a 473 critical role in social relationships. Thus, chimpanzees who shared the same mother did not 474 affiliate or cooperate more often than expected by chance (Goldberg \& Wrangham, 1997; John 
475 C Mitani et al., 2002). Although these relationships with maternal brothers appear to be

476 important in infancy, demographic constraints on general availability of maternal brothers as

477 potential coalition partners is believed to limit chimpanzee affiliation with maternal brothers

478 (Goldberg \& Wrangham, 1997; John C Mitani et al., 2002). On the basis of findings on

479 affiliation and kinship among chimpanzee brothers we expected to find a weak affiliative

480 relationships within mother and the adult offspring dyads. Against our expectation we found that

481 mother offspring dyads maintained close proximity more often than unrelated dyads in co-

482 feeding context but not other contexts. Although adult chimpanzees and mothers appear not to

483 affiliate, they nonetheless remain in proximity in competitive contexts. This raises an important

484 question as to why adult offspring chimpanzees co-feed with mothers if they do not affiliate with

485 them. Research across chimpanzee populations in Africa shows that both adult male and female

486 chimpanzees experience high levels of competition for plant food suggesting that these costs

487 may be reduced by co-feeding with kin (Muller, 2002). Females who are unable to monopolize

488 feeding site alone may engage in co-feeding with adult sons or daughters, thus enhancing their

489 feeding success. In humans, unrelated individuals cooperate contingent upon strength of a social

490 bond (friendship) and potential for reciprocity, whereas kinship has a direct effect on level of

491 cooperation that is independent of social bond strength or reciprocity - the phenomenon termed

492 'kinship premium' (Curry, Roberts, \& Dunbar, 2013). Kinship is more resilient to decay

493 overtime, whereas friendships require more investment into social contact to maintain them at a

494 level of strong social bonding (S. G. Roberts \& Dunbar, 2011). The current finding in the

495 chimpanzees that co-feeding with kin occurs in absence of affiliation, suggests that one might

496 expect a similar effect of 'kinship premium' in the chimpanzees. The observations that unrelated

497 sex and reproductive cohort dyads maintain proximity during feeding in presence of affiliation

498 supports this suggestion.

499 Comparably important to kinship are relationships with partners from the same age 500 cohort (Altmann, 1979). These relationships develop in infancy through association between 
501 mothers (Murray et al., 2014). Mirroring previous findings across Africa, the results show that

502 these dyads are associated with high rates of affiliation in many different contexts ( $K$.

503 Langergraber et al., 2009; K. E. Langergraber et al., 2007; J.C. Mitani, Watts, \& Muller, 2002). By

504 expectation, the positive association between co-feeding and kinship should therefore also have

505 emerged in the same age cohorts. However, these dyads differed in the patterns of co-feeding

506 from other dyads. Chimpanzees from the same age cohort did not spend more time co-feeding

507 in proximity than chimpanzees from different age cohort. Although these dyads share important

508 interactions and behaviours, these relationships appear competitive and costly, possibly due to

509 the fact that same age partners occupy similar niche and this might create greater competition.

510 For instance, studies of mountain gorillas showed that when there is a high degree of co-feeding,

511 individuals deal with competition by using different parts from the same food source (Watts,

512 1992). In contrast, same age cohort chimpanzees compete for the same food, dominance status,

513 and position in the network. Same age partners share similar rank, but this equitability may create

514 social relationships prone to decay because there is no prior consensus about the direction of

515 potential aggression (F. B. de Waal, 1986; Flack, De Waal, \& Waal, 2004). Indeed, partners of the

516 same age class in rhesus macaques have been found to display high rates of both aggression and

517 affiliation (Widdig, Nurnberg, Krawczak, Streich, \& Bercovitch, 2002). To uncover the extent to

518 which this lack of co-feeding in same age cohorts is generalizable to other sites it is first

519 important to examine these relationships in small and large parties of chimpanzees, as these

520 differ in the degree of feeding competition. In large parties when the feeding competition is

521 greater, chimpanzees may associate with kin to diffuse competition, but in smaller parties they

522 may well co-feed with same age partners.

523 Chimpanzees distribute their affiliative and competitive behaviour according to kinship

524 and demography. However, can gestural communication play a role if influence of these factors

525 has been discounted? In other words, are chimpanzees more affiliative than would be expected

526 by chance, if affiliation was dependent on gestural communication alone? Here our findings 
527 contribute to prior research by showing that gestural communication exerts important influence

528 on patterns of social affiliation among chimpanzee dyads. After controlling for kinship and

529 demography, the data shows that chimpanzees spend longer duration of time affiliating with the

530 individuals with whom they communicate through gestures. Thus, as there is an increase in the

531 duration of time $A$ spends in social behaviour with $B$, there is a corresponding increase or

532 decrease in the rate of gestural communication emitted by A to B. These findings support earlier

533 research from vocal modality which showed that sociality is associated with use of vocal

534 communication (McComb \& Semple, 2005). Affilitive gestures such as gestures to initiate

535 grooming or play appear to have an especially important influence on affiliation. Affiliative

536 gestural communication positively influenced the duration of time spent in social behaviour,

537 whereas antagonistic gestural communication negatively influenced duration of time spent in

538 social behaviour. For instance, the higher rate of gestures to initiate giving grooming predicts

539 longer grooming, whereas higher rate of gestures to threaten predict shorter grooming. Thus,

540 affiliative gestures are important in maintaining social relationships and function to coordinate

541 these interactions. For instance, affiliative gestural communication is more common in socially

542 complex egalitarian pigtail macaques, than in less socially complex and despotic rhesus macaques

543 (Maestripieri, 1999).

544 However, affiliation contexts are not uniformly associated with different degrees of

545 gestural complexity but there is a vast variation in how these measures of complexity are

546 distributed across contexts. In contexts signifying stronger social bonding (e.g. mutual grooming,

547 joint travel, mutual visual monitoring) gestures are primarily of low intensity (visual or auditory

548 short range), ranging from 16 to 17 different forms, that are more complex (e.g. use of facial

549 expressions, gestures were combined with other gesture types). In contrast, in contexts signifying

550 weaker social bonding (e.g. unidirectional grooming) (Noë, 2006) gestures are of higher intensity

551 (tactile, auditory), take 13 different forms that tend to be simpler (e.g. unimodal gesture, non- 
552 combined with other gesture types). Gestures given in strong social bonding contexts may

553 therefore be qualitatively different from gestures given when social bonds are weaker.

554 Why is there such a variation in gesture complexity across contexts? Is this variation 555 attributed to the efficiency with which communication can influence the recipient? The most 556 parsimonious explanation of these data is that chimpanzees in the wild are making decisions on 557 how to communicate, by choosing the gestures that can best influence the recipient in the given 558 context. Our data supports previous research suggesting that there are two key pathways to 559 achieving a greater efficiency in gestural communication. Studies in chimpanzees, showed how 560 intensity of communication can influence efficiency of social bonding in relation to its 561 effectiveness of conveying signaller's goal specifically (A. I. Roberts \& S. G. B. Roberts, 2016). 562 For instance, visual bodily gestures accompanied by direct gaze and pointing, have a greater 563 success in coordinating proximity with the recipient than when using visual bodily gestures alone 564 (Conty et al., 2012; S. Roberts \& A. I. Roberts, 2018). Thus by making low intensity, inspecific 565 gestures more complex, signallers can increase specificity of their gestures and elicit more 566 accurate response from the recipient. Another way to increase specificity of the gesture is by 567 increasing their intensity and therefore greater complexity of the gesture is not required (A. I.

568 Roberts \& S. G. B. Roberts, 2016). This link between intensity of communication and specificity 569 of the response has been shown in studies of nonverbal communication in humans (Zajonc \& 570 Sales, 1966). As the intensity of the signal increases, the mapping between structure of the signal 571 and the accompanying context becomes tighter enabling recipient to more accurately make the 572 association between the signal and the signaller's goal. Finally, adding rewarding property to the 573 signal may increase signal's effectiveness in conducting successful interaction (A. I. Roberts \& S. 574 G. B. Roberts, 2018). These rewarding properties promote greater commitment to the 575 interaction so that the recipient is more likely to respond to the gesture.

576 The relationships based on behaviours such as mutual grooming or travel appear to be 577 more mutually appealing as shown by a longer duration of time invested in these behaviours 
578 between partners who spend more time in proximity. These relationships are more common

579 between same age cohort partners - growing up together provides context whereby dyads share

580 many similarities and are highly familiar with each other. However, a whole range of signals

581 responsible for maintaining these interactions, for example visual gestures, persistence,

582 repertoire, facial expression were associated with higher rate of self-scratch, indicating higher

583 anxiety experienced by the signallers towards recipients of these gestures. One type of answer

584 that can be given to the question of why chimpanzees experienced higher anxiety in response to

585 communicating with social partners with whom they displayed a higher rate of affiliative

586 behaviour is that social relationships with these social partners have been uncertain due to

587 unresolved dominance relationships. What has long puzzled anthropologists is that dominance

588 hierarchy can sometimes lead to greater social cohesion because it enables signaller to more

589 effectively predict outcome of the interaction before they engage in the interaction with the

590 recipient (Flack, Girvan, De Waal, \& Krakauer, 2006). Classical ethologists have shown very

591 clearly how lack of linear dominance hierarchy can make animal societies less predictable and

592 more aggressive (Flack, de Waal, \& Krakauer, 2005) demanding complex but low intensity

593 communication to resolve ambiguity in social relationships (A. I. Roberts et al., 2019). This

594 communication can increase trust of the recipient, as it may appear more positive, therefore

595 creating a perception of a fitness rewarding intent of the signaler (Roberts \& Roberts, 2016a). In

596 social relationships with dominant chimpanzees, the risks of interaction and direction of

597 potential aggression is known in advance and therefore dominance relationships increase

598 certainty by having predictable outcomes (Ay, Flack, \& Krakauer, 2007; Flack et al., 2006). In

599 contrast, equitable ranks are less predictable in that both interactants are equally likely to win if

600 engaged in a fight resulting in high levels of uncertainty. The mutual appeal that draws

601 chimpanzees together in these social interactions, has been insufficient and the power of gestural

602 communication has been exploited to facilitate social interactions between these partners. Low

603 intensity signals designed to effectively convey the intentions of a signaller in a way that leads to 
604 a reduction in uncertainty of the recipient about the signaller's goal encompass all common 605 signals seen in these contexts.

606 In contrast, the relationships based on behaviours such as unidirectional grooming are 607 often directed towards chimpanzees who display higher rank. Gestures made in unidirectional 608 grooming context were associated with reduced rate of self-scratching by the recipient, 609 suggesting that recipients experience reduced anxiety when receiving these gestures. This reveals 610 a possible lack of mutual appeal in these interactions as the signaller actively influences 611 recipient's positive affect to enhance its willingness to associate. As the anxiety is reduced, the 612 signaller increases recipient's commitment to the social interaction forging stronger social 613 bonding. Thus, in these contexts, in addition to conveying goals effectively through more intense 614 gestures, use of signals that increase rewards are important to succeed in engaging the recipient 615 who may otherwise not be particularly interested in the interaction.

616 The differentiated communication strategies of the chimpanzees may have evolved in 617 response to the demands imposed by competition in complex social settings. Both male and 618 female chimpanzees often compete for food and individual's ability to gain access to food can 619 influence their reproductive success (Muller, 2002). Evidence from chimpanzees indicates that 620 social variables such as party size can affect individual's relative competitive success in feeding 621 contexts. Chimpanzees in larger parties derive benefits from lower predation pressure but may 622 face a higher feeding competition than the chimpanzees in smaller parties. Competition for food 623 may therefore promote evolution of the strategies the individuals use to diffuse this competition. 624 Influential strategy includes grooming to reduce likelihood of potential aggression during co625 feeding. In small social groups, chimpanzees face lower social competition and thus can invest in 626 grooming with the social partners that are insecure but appealing. However, when the size of the 627 group increases, the safety of secure relationships promotes feeding efficiency and therefore 628 grooming interactions focus on these social partners. Tactile gestures that have a rewarding 629 property can compete for recipient's attention in larger groups more effectively than visual 
630 gestures by being more capable of redirecting recipient's attention from the wider audience onto

631 the signaller. Furthermore, rewarding gestures may have a better coordination value by being

632 able to influence recipient's behaviour more directly through more intense and specific gestures

633 (A. I. Roberts \& S. G. B. Roberts, 2016). Studies showed that when larger audience is present,

634 both rewarding and coordination properties of gestural communication facilitate longer

635 grooming and this in turn is associated with longer co-feeding in proximity (A. I. Roberts, 2018).

636 Given the time budgeting constraints on grooming (Dunbar, 1992), there may be a limit for use

637 of grooming as a tool for diffusing social competition in feeding contexts. Our data reveals that

638 chimpanzees incorporated use of objects and vocalisations when gesturing towards conspecifics

639 with whom they spent short periods of time in proximity. Similarly, use of objects such as a

640 trunk of a tree to make sounds accompanied by use of rhythmic vocalisations ('synchronized

641 high-intensity pant hoot') may potentially fulfil such a function as this communication is used

642 most often when joining feeding sites or during travel (Clark \& Wrangham, 1994; S. G. B.

643 Roberts \& A. I. Roberts, 2016). Supporting these suggestions, our evidence shows that

644 synchronized high-intensity pant hoots were associated with reduced displacement behaviours in

645 the recipient. When social parties become large, the ability to groom with conspecifics may

646 decline and 'synchronized high-intensity pant hoot' may facilitate social cohesion by reducing

647 anxiety of the recipients (S. G. B. Roberts \& A. I. Roberts, 2016). This property may draw

648 attention of the recipients from the wider audience onto the signaller facilitating longer

649 interactions such as travel or co-feeding. This finding supports research on humans (Jackson et

650 al., 2018) showing that joint, high intensity behaviours have a role in social cohesion by being

651 intensely rewarding to the dyad partners, regardless of the history of prior interaction.

652 The complexity of a social system depends on the complexity of individual relationships

653 between animals, as the individual-level social interactions scale to the emergent properties found

654 in the social system (Krause, Croft, \& James, 2007). In this study we highlight the tactical

655 decisions that wild chimpanzees make in their use of gestural communication to develop and 
656 maintain complexity of their social system. The selective pressures arising from maintaining this

657 social complexity is proposed to have played a key role both in the evolution of communicative 658 complexity and in the evolution of larger brains both in primates and in hominins. However, 659 detailed behavioural evidence of an association between communicative complexity and these 660 differentiated social relationships is lacking. Here we address this issue by examining how 661 different types of social behaviour relate to patterns of gestural communication. Overall, our 662 results suggest that differentiated patterns of gestural communication can help chimpanzees 663 maintain a network of differentiated social relationships, and that this may allow individual 664 primates to successfully navigate a complex social world. Future studies exploring the 665 relationship between the complexity of communication skills, sociality and brain size across a 666 range of primate species would allow for a deeper understanding of the association between 667 complex social systems and complex communication.

\section{Acknowledgement}

669 The data collection was funded by the Economic and Social Research Council 3+ fellowship and 670 the University of Stirling. We thank the Royal Zoological Society of Scotland for providing core 671 funding to the Budongo Conservation Field Station, Uganda, as well as the Ugandan Wildlife 672 Authority and the Uganda National Council for Science and Technology for permission to carry out this research. We are most grateful to Prof. Klaus Zuberbuhler and Geresomu Muhumuza 674 for fantastic fieldwork.

Altmann, J. (1979). Age cohorts as paternal sibships. Behavioral Ecology and Sociobiology, 6(2), 161164. conflict resolution. Aggressive Behavior: Official Joumal of the International Society for Research on Aggression, 23(5), 315-328.

Aureli, F., \& Schaik, C. P. v. (1991). Post-conflict behaviour in long-tailed macaques (Macaca fascicularis) II. Coping with the uncertainty. Ethology, 89(2), 101-114. multimodal signalling networks. Philosophical Transactions of the Royal Society B: Biological Sciences, 362(1479), 441-447. 
Baker, K. C., \& Aureli, F. (1997). Behavioural indicators of anxiety: an empirical test in chimpanzees. Behaviour, 134(13), 1031-1050.

Boesch, C. (1996). Social grouping in Tai chimpanzees. In W. C. McGrew, L. Marchant, \& T. Nishida (Eds.), Great Ape Societies (pp. 101-113). Cambridge: Cambridge University Press.

Borgatti, S. P., Everett, M. G., \& Johnson, J. C. (2013). Analyring Social Networks: SAGE Publications Limited.

Castles, D. L., \& Whiten, A. (1998). Post-conflict behaviour of wild olive baboons. II. Stress and self-directed behaviour. Ethology, 104(2), 148-160.

Clark, A. P., \& Wrangham, R. W. (1994). Chimpanzee arrival pant-hoots: Do they signify food or status? International Journal of Primatology, 15(2), 185-205.

Conty, L., Dezecache, G., Hugueville, L., \& Grèzes, J. (2012). Early binding of gaze, gesture, and emotion: neural time course and correlates. The Journal of Neuroscience, 32(13), 4531-4539.

Croft, D. P., James, R., \& Krause, J. (2010). Exploring Animal Social Networks. Princeton, New Yersey: Princeton University Press.

Curry, O., Roberts, S. G., \& Dunbar, R. I. (2013). Altruism in social networks: Evidence for a 'kinship premium'. British Journal of Psychology, 104(2), 283-295.

Dawkins, M. S., \& Guilford, T. (1997). Conspicuousness and diversity in animal signals. Communication, 55-75.

de Waal, F. B. (1986). The integration of dominance and social bonding in primates. Quarterly Review of Biology, 61 (4), 459-479.

De Waal, F. B. M. (1982). Chimpanzee politics: Power and sex among apes. New York: Harper \& Row.

Dekker, D., Krackhardt, D., \& Snijders, T. A. (2007). Sensitivity of MRQAP tests to collinearity and autocorrelation conditions. Psychometrika, 72(4), 563-581.

Diezinger, F. t., \& Anderson, J. (1986). Starting from scratch: A first look at a "displacement activity" in group-living rhesus monkeys. American journal of primatology, 11(2), 117-124.

Dunbar, R. I. M. (1992). Neocortex size as a constraint on group size in primates. Journal of Human Evolution, 20, 469-493.

Feldman, R., Gordon, I., \& Zagoory-Sharon, O. (2011). Maternal and paternal plasma, salivary, and urinary oxytocin and parent-infant synchrony: considering stress and affiliation components of human bonding. Developmental science, 14(4), 752-761.

Field, A. (2013). Discovering statistics using IBM SPSS statistics: sage.

Flack, J. C., de Waal, F. B., \& Krakauer, D. C. (2005). Social structure, robustness, and policing cost in a cognitively sophisticated species. The American Naturalist, 165(5), E126-E139.

Flack, J. C., De Waal, F. B., \& Waal, D. (2004). Dominance style, social power, and conflict management: a conceptual framework. In: Macaque Societies: A Model for the Study of Social Organization (Ed. by.

Flack, J. C., Girvan, M., De Waal, F. B., \& Krakauer, D. C. (2006). Policing stabilizes construction of social niches in primates. Nature, 439(7075), 426-429.

Foerster, S., McLellan, K., Schroepfer-Walker, K., Murray, C. M., Krupenye, C., Gilby, I. C., \& Pusey, A. E. (2015). Social bonds in the dispersing sex: partner preferences among adult female chimpanzees. Animal Behaviour, 105, 139-152.

Gerhardt, H. C., \& Doherty, J. A. (1988). Acoustic communication in the gray treefrog, Hyla versicolor: evolutionary and neurobiological implications. Journal of Comparative Physiology A, 162(2), 261-278.

Goldberg, T. L., \& Wrangham, R. W. (1997). Genetic correlates of social behaviour in wild chimpanzees: evidence from mitochondrial DNA. Animal Behaviour, 54(3), 559-570.

Goodall, J. (1986). The Chimpanzees of Gombe: Patterns of Behaviour. Cambridge, Massachusetts: Harward University Press.

Hamilton, W. D. (1964). The genetical evolution of social behaviour. II. Journal of theoretical biology, 7(1), 17-52. 
Hewes, G. W. (1973). Primate communication and the gestural origin of language. Current Anthropology, 14, 5-24.

Hinde, R. A. (1976). Interactions, relationships and social structure. Man, 1-17.

Jackson, J. C., Jong, J., Bilkey, D., Whitehouse, H., Zollmann, S., McNaughton, C., \& Halberstadt, J. (2018). Synchrony and Physiological Arousal Increase Cohesion and Cooperation in Large Naturalistic Groups. Scientific reports, 8(1), 127. doi:10.1038/s41598017-18023-4

Kerth, G., Perony, N., \& Schweitzer, F. (2011). Bats are able to maintain long-term social relationships despite the high fission-fusion dynamics of their groups. Proceedings of the Royal Society of London B: Biological Sciences, 278(1719), 2761-2767.

Krause, J., Croft, D., \& James, R. (2007). Social network theory in the behavioural sciences: Potential applications. Behavioral Ecology and Sociobiology, 62(1), 15-27.

Langergraber, K., Mitani, J., \& Vigilant, L. (2009). Kinship and social bonds in female chimpanzees (Pan troglodytes). American journal of primatology, 71(10), 840-851.

Langergraber, K. E., Mitani, J. C., \& Vigilant, L. (2007). The limited impact of kinship on cooperation in wild chimpanzees. Proceedings of the National Academy of Sciences, 104(19), 7786-7790.

Liebal, K., Call, J., \& Tomasello, M. (2004). Use of gesture sequences in chimpanzees. American journal of primatology, 64(4), 377-396.

Maestripieri, D. (1999). Primate social organization, gestural repertoire size, and communication dynamics: a comparative study of macaques. In B. J. King (Ed.), The origins of language: what nonhuman primates can tell us (pp. 55 - 77). Santa Fe: School of American Research Press.

Maestripieri, D. (2005). Gestural communication in three species of macaques (Macaca mulatta, M. nemestrina, M. arctoides): Use of signals in relation to dominance and social context. Gesture, 5(1), 55-71.

Massen, J. J., \& Koski, S. E. (2014). Chimps of a feather sit together: chimpanzee friendships are based on homophily in personality. Evolution and Human Behavior, 35(1), 1-8.

McComb, K., \& Semple, S. (2005). Coevolution of vocal communication and sociality in primates. Biology Letters, 1(4), 381-385.

Mitani, J. C., Watts, D. P., \& Muller, M. N. (2002). Recent developments in the study of wild chimpanzee behavior. Evolutionary Anthropology, 11(1), 9-25.

Mitani, J. C., Watts, D. P., Pepper, J. W., \& Merriwether, D. A. (2002). Demographic and social constraints on male chimpanzee behaviour. Animal Behaviour, 64(5), 727-737.

Möller, L. M., Beheregaray, L. B., Harcourt, R. G., \& Krützen, M. (2001). Alliance membership and kinship in wild male bottlenose dolphins (Tursiops aduncus) of southeastern Australia. Proceedings of the Royal Society of London B: Biological Sciences, 268(1479), 1941-1947.

Muller, M. N. (2002). Agonistic relations among Kanyawara chimpanzees. Behavioural diversity in chimpanzees and bonobos, 112-124.

Murray, C. M., Lonsdorf, E. V., Stanton, M. A., Wellens, K. R., Miller, J. A., Goodall, J., \& Pusey, A. E. (2014). Early social exposure in wild chimpanzees: Mothers with sons are more gregarious than mothers with daughters. Proceedings of the National Academy of Sciences, 111(51), 18189-18194.

Nakayama, K., Goto, S., Kuraoka, K., \& Nakamura, K. (2005). Decrease in nasal temperature of rhesus monkeys (Macaca mulatta) in negative emotional state. Physiology \& behavior, 84(5), 783-790.

Nishida, T., Zamma, K., Matsusaka, T., Inaba, A., \& McGrew, W. C. (2010). Chimpanzee behavior in the wild: An audio-visual encyclopedia. Tokyo: Springer.

Noë, R. (2006). Cooperation experiments: coordination through communication versus acting apart together. Animal Behaviour, 71(1), 1-18. 
Ortega-Ortiz, J. G., Engelhaupt, D., Winsor, M., Mate, B. R., \& Rus Hoelzel, A. (2012). Kinship of long-term associates in the highly social sperm whale. Molecular Ecology, 21(3), 732-744.

PAYNE, R. J., \& PAGEL, M. (1997). Why do animals repeat displays? Animal Behaviour, 54(1), 109-119.

Pearce, E., Wlodarski, R., Machin, A., \& Dunbar, R. I. (2017). Variation in the $\beta$-endorphin, oxytocin, and dopamine receptor genes is associated with different dimensions of human sociality. Proceedings of the National Academy of Sciences USA, 201700712.

Roberts, A. I. (2018). Influence of party size on social bonding and gestural persistence in wild chimpanzees. Advances in Biology and Earth Scienes, 3(3), 205 -228.

Roberts, A. I., Chakrabarti, A., \& Roberts, S. G. B. (2019). Gestural repertoire size is associated with social proximity measures in wild chimpanzees. American journal of primatology, e22954. doi:10.1002/ajp.22954

Roberts, A. I., \& Roberts, S. G. B. (2015). Gestural communication and mating tactics in wild chimpanzees. PloS One, 10(11), e0139683. doi:10.1371/journal.pone.0139683

Roberts, A. I., \& Roberts, S. G. B. (2016). Wild chimpanzees modify modality of gestures according to the strength of social bonds and personal network size. Scientific reports, 6(33864). doi:10.1038/srep33864

Roberts, A. I., \& Roberts, S. G. B. (2017). Convergence and divergence in gestural repetoires as an adaptive mechanism for social bonding in primates. Royal Society Open Science, 4: 170181. doi:https://doi.org/10.1098/rsos.170181

Roberts, A. I., \& Roberts, S. G. B. (2018). Persistence in gestural communication predicts sociality in wild chimpanzee. Animal Cognition. doi:10.1101/365858

Roberts, A. I., Roberts, S. G. B., \& Vick, S.-J. (2014). The repertoire and intentionality of gestural communication in wild chimpanzees. Animal Cognition, 17(2), 317 - 336. doi:10.1007/s10071-013-0664-5

Roberts, A. I., Vick, S.-J., \& Buchanan-Smith, H. (2012). Usage and comprehension of manual gestures in wild chimpanzees. Animal Behaviour, 84(2), 459-470. doi:10.1016/j.anbehav.2012.05.022

Roberts, A. I., Vick, S.-J., \& Buchanan-Smith, H. (2013). Communicative intentions in wild chimpanzees: Persistence and elaboration in gestural signalling. Animal Cognition, 16(2), 187-196. doi:10.1007/s10071-012-0563-1

Roberts, A. I., Vick, S.-J., Roberts, S. G. B., Buchanan-Smith, H. M., \& Zuberbühler, K. (2012). A structure-based repertoire of manual gestures in wild chimpanzees: Statistical analyses of a graded communication system. Evolution and Human Behavior, 33(5), 578-589. doi:10.1016/j.evolhumbehav.2012.05.006

Roberts, A. I., Vick, S.-J., Roberts, S. G. B., \& Menzel, C. R. (2014). Chimpanzees modify intentional gestures to coordinate a search for hidden food. Nature Communications 5 , 3088. doi: 10.1038 .ncomms4088

Roberts, S., \& Roberts, A. I. (2018). Visual attention, indicative gestures, and calls accompanying gestural communication are associated with sociality in wild chimpanzees (Pan troglodyres schweinnfurthii). Journal of Comparative Psychology. doi:10.1037/com0000128

Roberts, S. G., \& Dunbar, R. I. (2011). The costs of family and friends: an 18-month longitudinal study of relationship maintenance and decay. Evolution and Human Behavior, 32(3), 186197.

Roberts, S. G. B., \& Roberts, A. I. (2016). Social brain hypothesis, vocal and gesture networks of wild chimpanzees. Frontiers in psychology, 7(1756). doi:10.3389/fpsyg.2016.01756

Schino, G., Perretta, G., Taglioni, A. M., Monaco, V., \& Troisi, A. (1996). Primate displacement activities as an ethopharmacological model of anxiety. Anxiety, 2(4), 186-191.

Schino, G., Scucchi, S., Maestripieri, D., \& Turillazzi, P. G. (1988). Allogrooming as a tension reduction mechanism: A behavioral approach. American joumal of primatology, 16(1), 43-50. 
836

Silk, J. B., Seyfarth, R. M., \& Cheney, D. L. (2018). Quality versus quantity: do weak bonds enhance the fitness of female baboons? Animal Behaviour, 140, 207-211.

Silk, M. J., Jackson, A. L., Croft, D. P., Colhoun, K., \& Bearhop, S. (2015). The consequences of unidentifiable individuals for the analysis of an animal social network. Animal Behaviour, 104, 1-11.

Van Schaik, C. P., \& Van Hooff, J. A. (1994). Male bonds: afilliative relationships among nonhuman primate males. Behaviour, 130(3-4), 309-337.

Watts, D. P. (1992). Social relationships of immigrant and resident female mountain gorillas. I. Male-female relationships. American joumal of primatology, 28(3), 159-181.

Widdig, A., Nurnberg, P., Krawczak, M., Streich, W. J., \& Bercovitch, F. (2002). Affiliation and aggression among adult female rhesus macaques: a genetic analysis of paternal cohorts. Behaviour, 139(2-3), 371-392.

Wrangham, R. W. (1980). An ecological model of female-bonded primate groups. Behaviour, 75(3), 262-300.

Zahavi, A., \& Zahavi, A. (1997). The handicap principle: a missing piece of Darwin's purale: Oxford University Press.

Zajonc, R. B., \& Sales, S. M. (1966). Social facilitation of dominant and subordinate responses. Joumal of Experimental Social Psychology, 2(2), 160-168.

Table 1: Focal ID, sex, year of birth, kinship and reproductive status of the 12 focal subjects included in the study.

\begin{tabular}{|c|c|c|c|c|c|}
\hline $\begin{array}{l}\text { Focal } \\
\text { subject ID }\end{array}$ & Sex & Age & $\begin{array}{l}\text { Female } \\
\text { reproductive } \\
\text { status }\end{array}$ & Kinship & $\begin{array}{l}\text { Total observation } \\
\text { duration } \\
\text { (minutes) }\end{array}$ \\
\hline$\overline{\mathrm{KU}}$ & Female & 29 & Pregnant & K'T (son) & 910 \\
\hline KW & Female & 27 & Nursing & & 510 \\
\hline ML & Female & 33 & Cycling & & 1118 \\
\hline $\mathrm{NB}^{\mathrm{b}}$ & Female & 46 & Cycling & MS (son) & 500 \\
\hline $\mathrm{RH}$ & Female & 43 & Nursing & NK (son) & 1038 \\
\hline $\mathrm{ZM}$ & Female & 40 & Cycling & & 710 \\
\hline BB & Male & 21 & - & & 516 \\
\hline HW & Male & 15 & - & & 1030 \\
\hline $\mathrm{KT}$ & Male & 15 & - & KU (mother) & 1026 \\
\hline
\end{tabular}




\begin{tabular}{|l|l|l|l|l|l|}
\hline MS & Male & 17 & - & NB (mother) & 524 \\
\hline NK $^{\text {a }}$ & Male & 26 & - & RH (mother) & 582 \\
\hline SQ & Male & 17 & - & & 554 \\
\hline
\end{tabular}

Table 2. Definitions, means and standard deviations (SD) for social behaviours, based on 132 engaged in the same behaviour. The behaviors are described in depth in (Nishida et al., 2010).

\begin{tabular}{|l|l|l|}
\hline Behaviour & Definition & Mean \pm SD \\
\hline Joint feeding & Focal and non-focal subject consume food simultaneously & $1.25 \pm 2.53$ \\
\hline Joint resting & Focal and non-focal subject are in resting position not & $1.56 \pm 5.73$ \\
\hline Joint travel & Focal and non-focal subjects simultaneously relocate from one & $0.44 \pm 1.58$ \\
\hline Grooming & Focation in the habitat to another & \\
given & parasite from their hair. & \\
\hline Grooming & Focal subject receives grooming from non-focal subject who is & $0.67 \pm 2.55$ \\
received & picking dirt and parasites from their hair. & \\
\hline Grooming & Both focal and non-focal subject simultaneously pick dirt and \\
mutual & parasites from hair of one another. & $0.53 \pm 2.13$ \\
\hline Attention & Both focal and non-focal subjects are bodily oriented towards & $3.04 \pm 5.68$ \\
\hline
\end{tabular}




\begin{tabular}{|c|c|c|}
\hline & degrees body turn) & \\
\hline $\begin{array}{l}\text { Attention } \\
\text { absent }\end{array}$ & $\begin{array}{l}\text { Both focal and non-focal subjects are bodily oriented away } \\
\text { from one another (one has another away from field of view up } \\
\text { to } 45 \text { degrees body turn) }\end{array}$ & $1.84 \pm 5.68$ \\
\hline Proximity & $\begin{array}{l}\text { Focal and non-focal subjects are within } 2 \text { meters of one } \\
\text { another }\end{array}$ & $6.16 \pm 10.05$ \\
\hline $\begin{array}{l}\text { Scratch } \\
\text { produced }\end{array}$ & $\begin{array}{l}\text { Focal subject rakes with the fingers through their own hair } \\
\text { repeatedly or singly - all chimpanzee scratch (social and non- } \\
\text { social) was included }\end{array}$ & $0.64 \pm 1.68$ \\
\hline $\begin{array}{l}\text { Scratch } \\
\text { received }\end{array}$ & $\begin{array}{l}\text { Focal subject is recipient of the scratch whereby the non-focal } \\
\text { subject rakes their own hair with the fingers through the hair } \\
\text { repeatedly or singly (all types of scratch were included) }\end{array}$ & $0.64 \pm 1.68$ \\
\hline
\end{tabular}

864 Table 3. Attributes used to classify dyads

\begin{tabular}{|l|l|}
\hline Attribute of dyad & Description \\
\hline Sex difference & $\begin{array}{l}\text { Sex difference between focal subject and the recipient }(0=\text { opposite } \\
\text { sex, } 1=\text { same sex })\end{array}$ \\
\hline Age difference & $\begin{array}{l}\text { Age difference between focal subject and the recipient: } 0=\text { different } \\
\text { age (more than } 5 \text { years age difference with the dyad partner), } 1= \\
\text { same age (up to } 5 \text { years age difference) }\end{array}$ \\
\hline Reproductive & $\begin{array}{l}\text { Reproductive state difference between focal subject and the } \\
\text { recipient }(0=\text { different reproductive state: unoestrous female- } \\
\text { oestrous female, unoestrous female-male dyad; } 1 \text { same } \\
\text { reproductive state: male-male, male-oestrous female, oestrous female }\end{array}$ \\
\hline
\end{tabular}




\begin{tabular}{|l|l|}
\hline & $\begin{array}{l}- \text { male, unoestrous female }- \text { unoestrous female, oestrous female- } \\
\text { oestrous female dyad, etc.) }\end{array}$ \\
\hline Maternal kinship & $\begin{array}{l}\text { Maternal kinship (mother-offspring or offspring-mother) presence } \\
\text { between focal subject and the recipient }(0=\text { absent, } 1=\text { present })\end{array}$ \\
\hline
\end{tabular}

866 Figure 1. Social networks: a) attention absent, b) attention present, c) proximity, d) joint feeding,

867 e) grooming given, f) grooming mutual, g) grooming received, h) joint resting, i) joint travel, j)

868 scratch produced, k) scratch received

$869 \quad$ a)

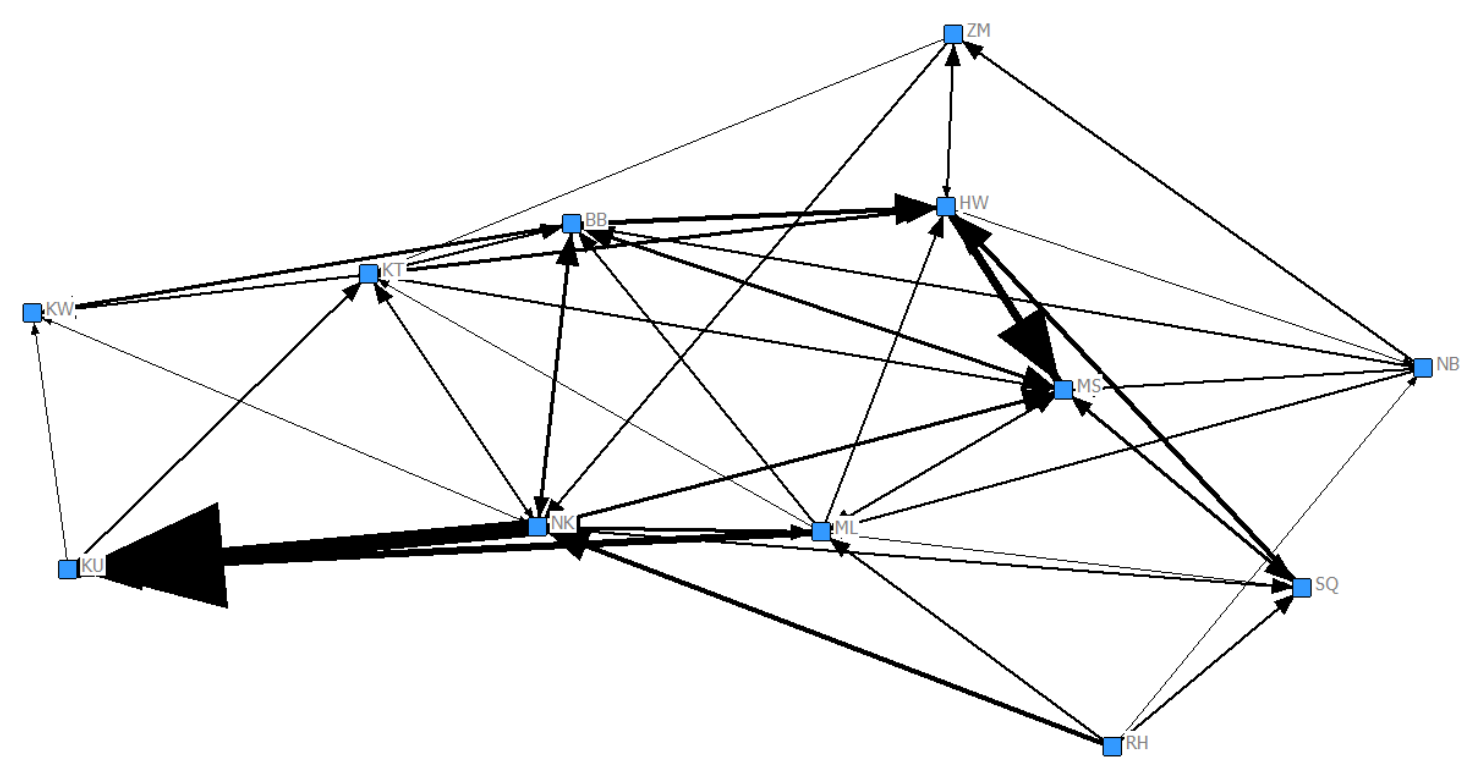

871 b) 
bioRxiv preprint doi: https://doi.org/10.1101/678805; this version posted June 21, 2019. The copyright holder for this preprint (which was not certified by peer review) is the author/funder. All rights reserved. No reuse allowed without permission.

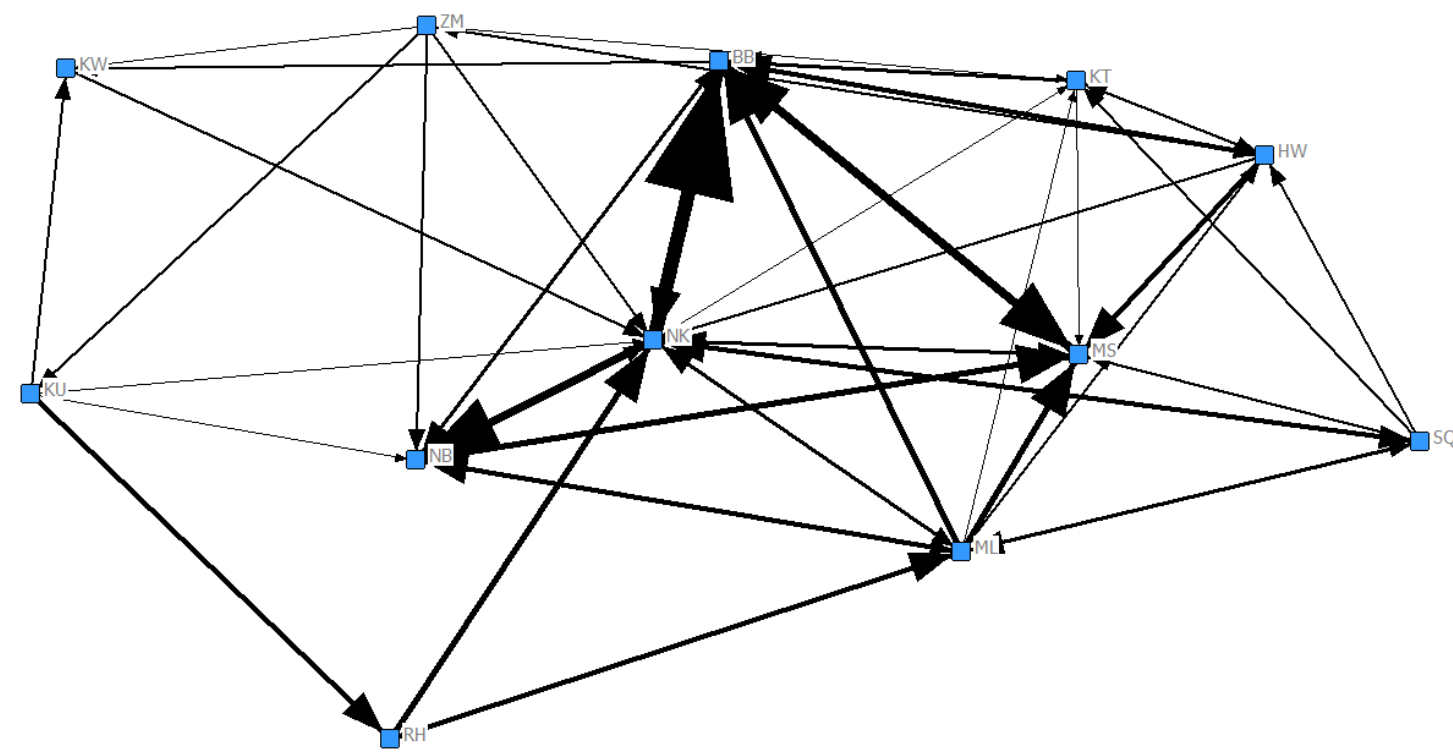

$873 \mathrm{c})$

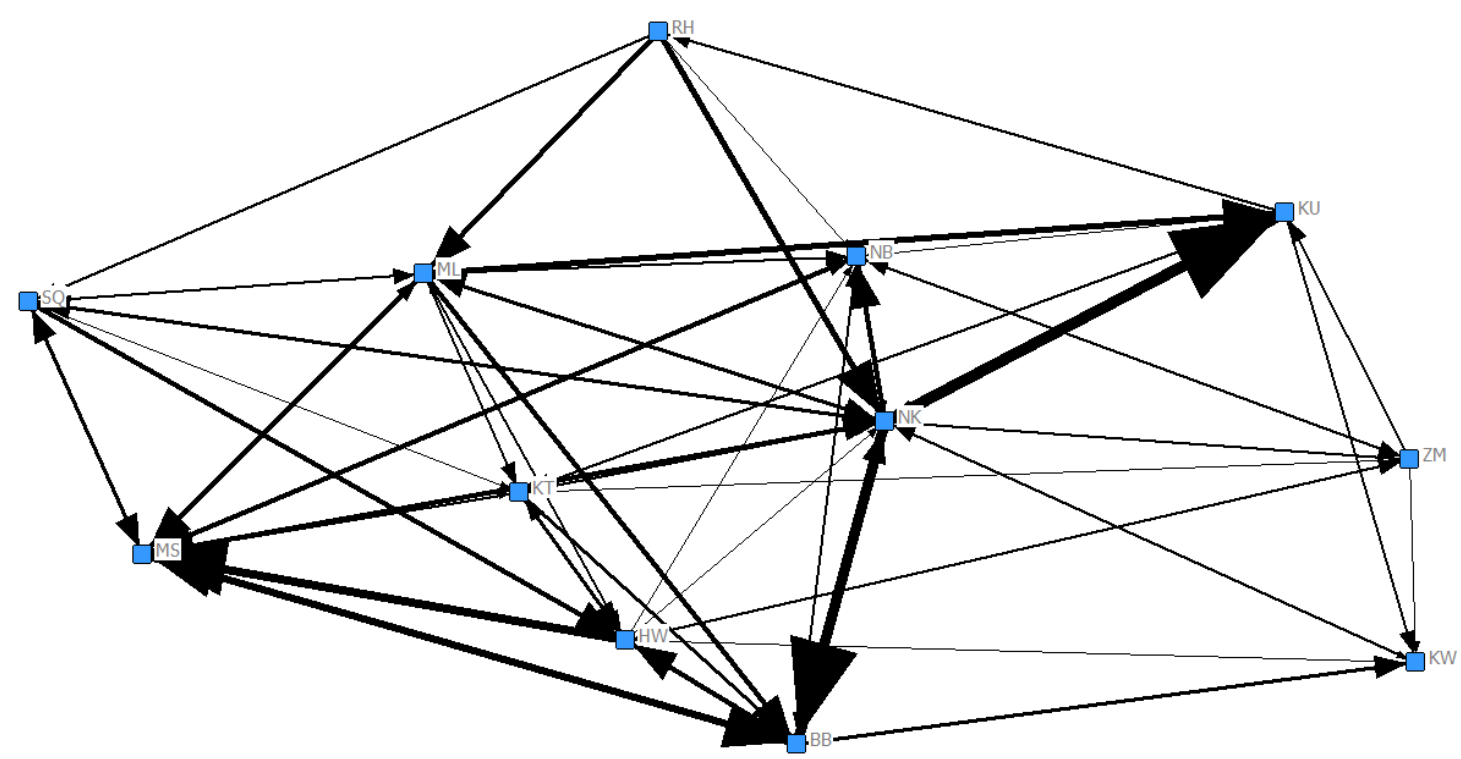

875 d) 


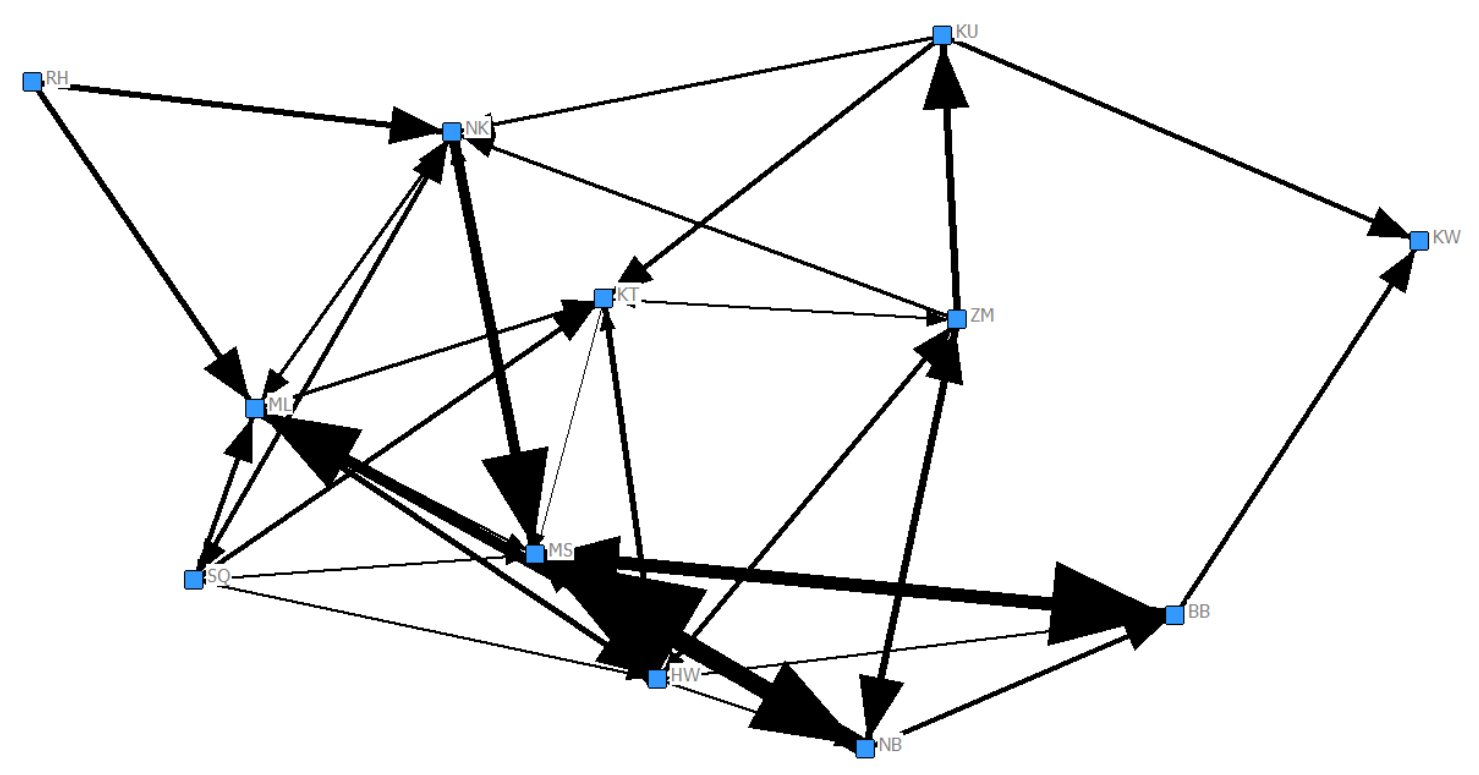

877 e)

878

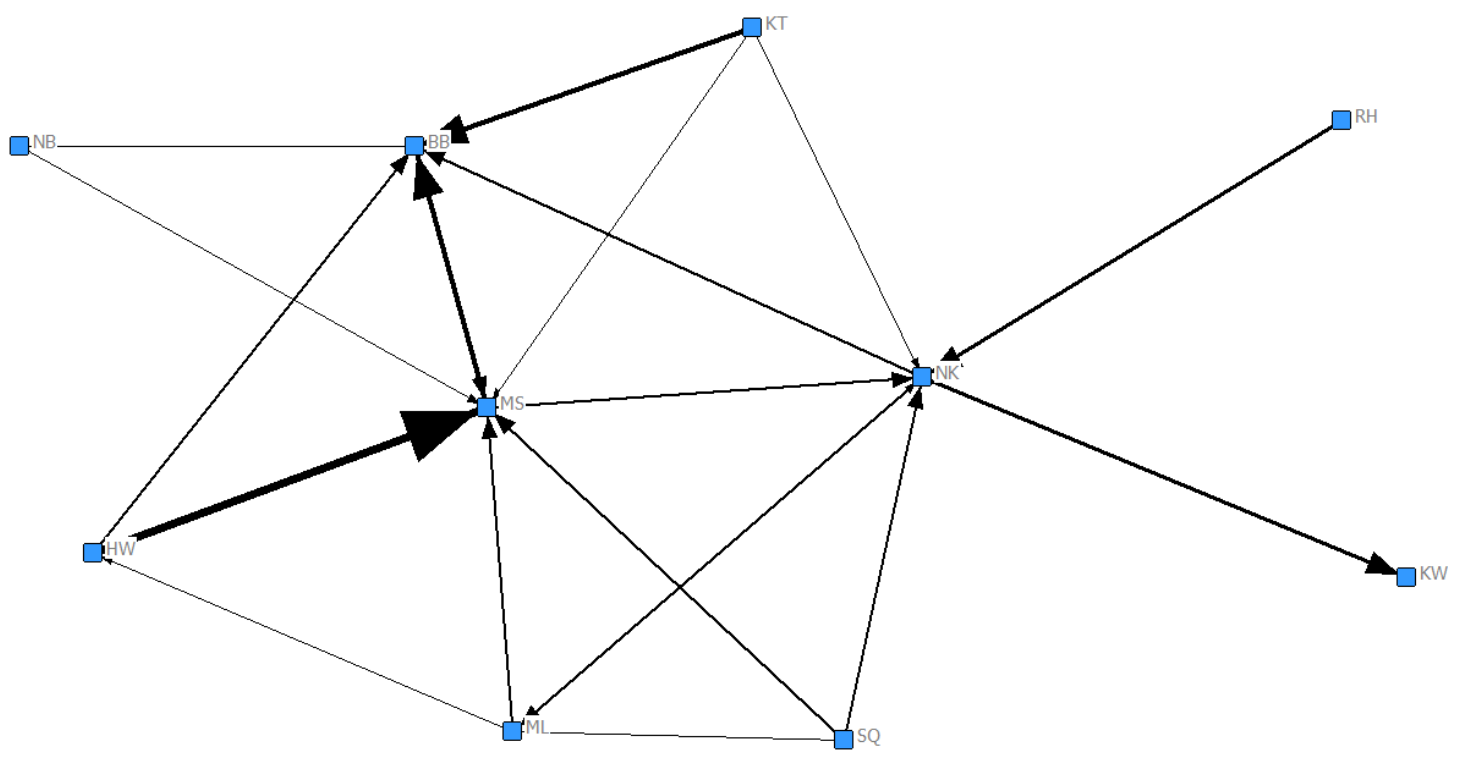

879 f) 


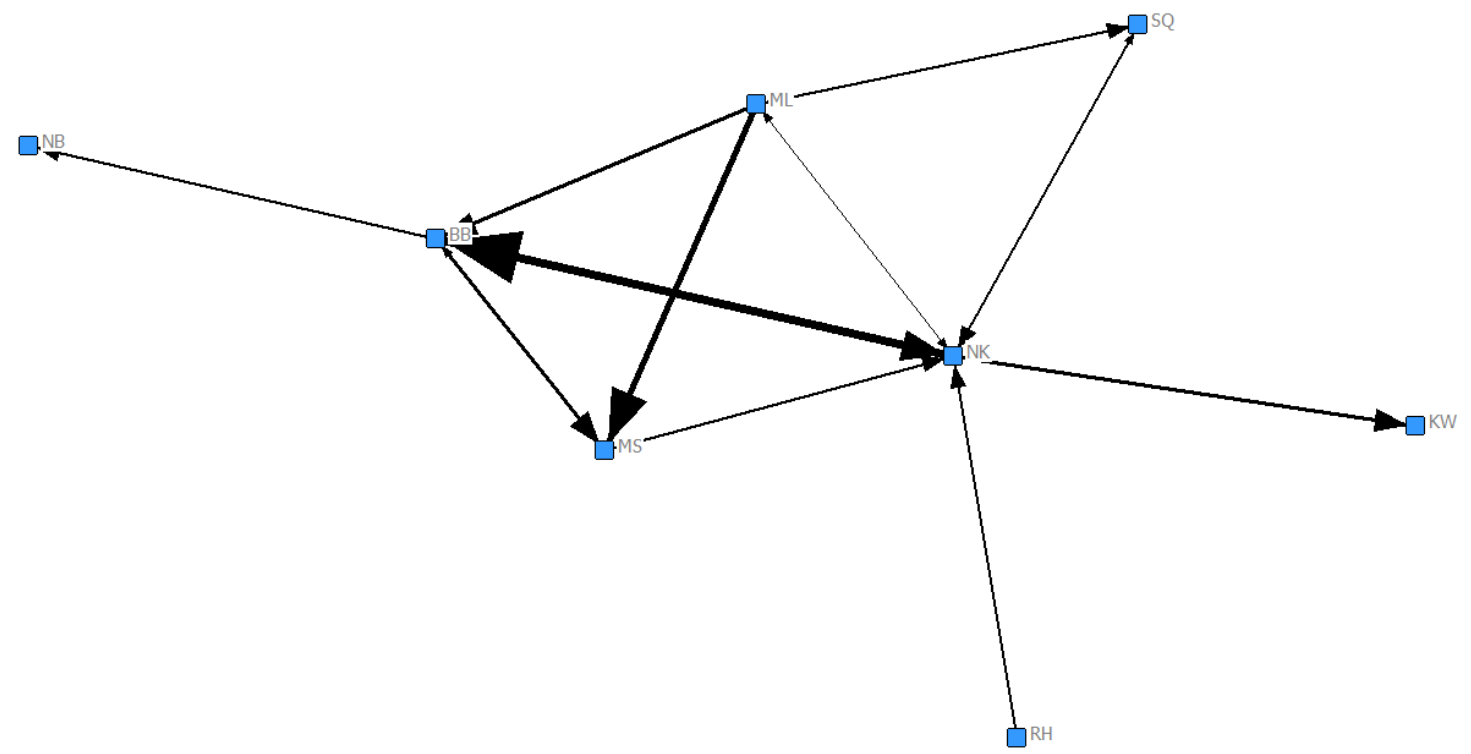

881 g)

882

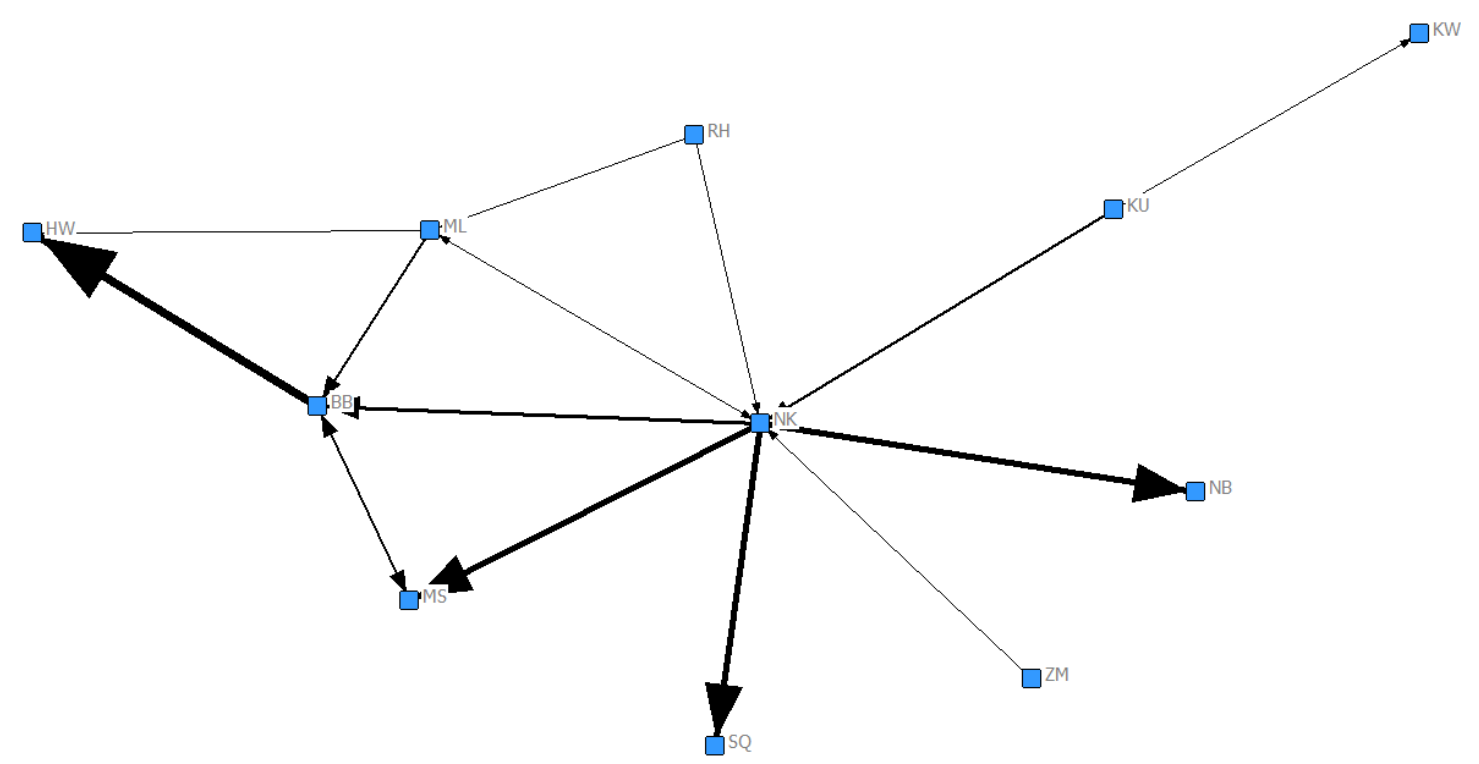

883

884 h) 


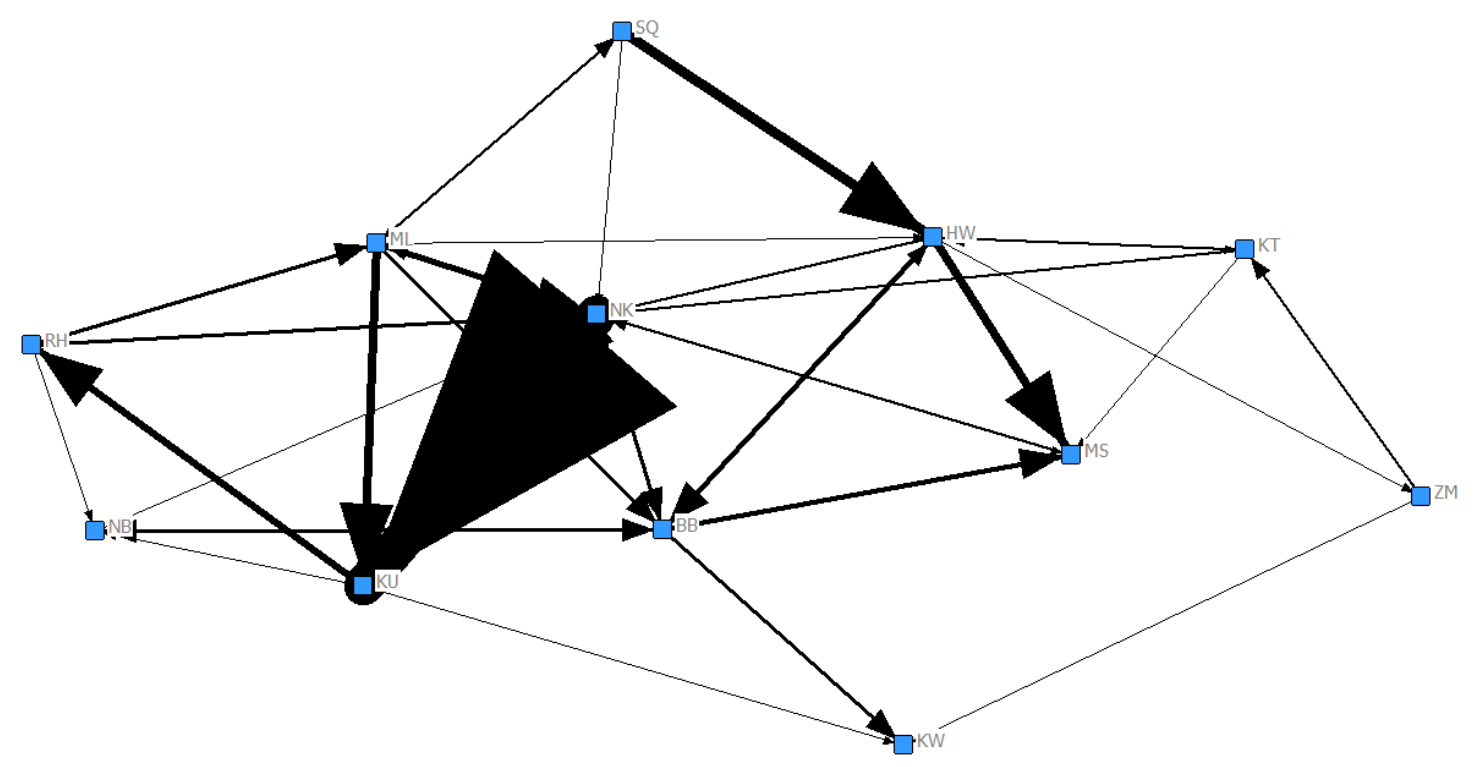

$886 \quad$ i)

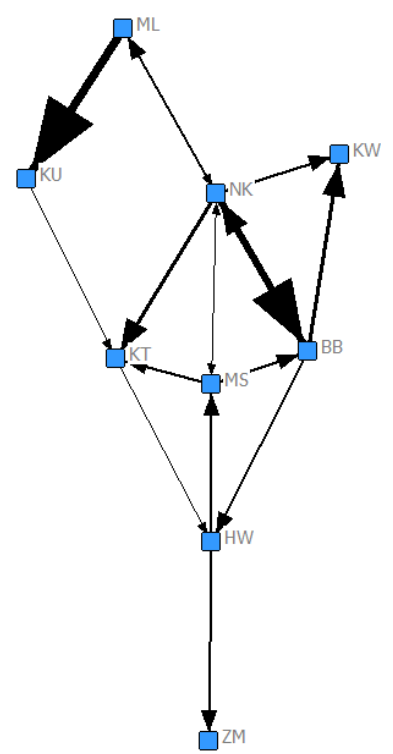

888 j) 

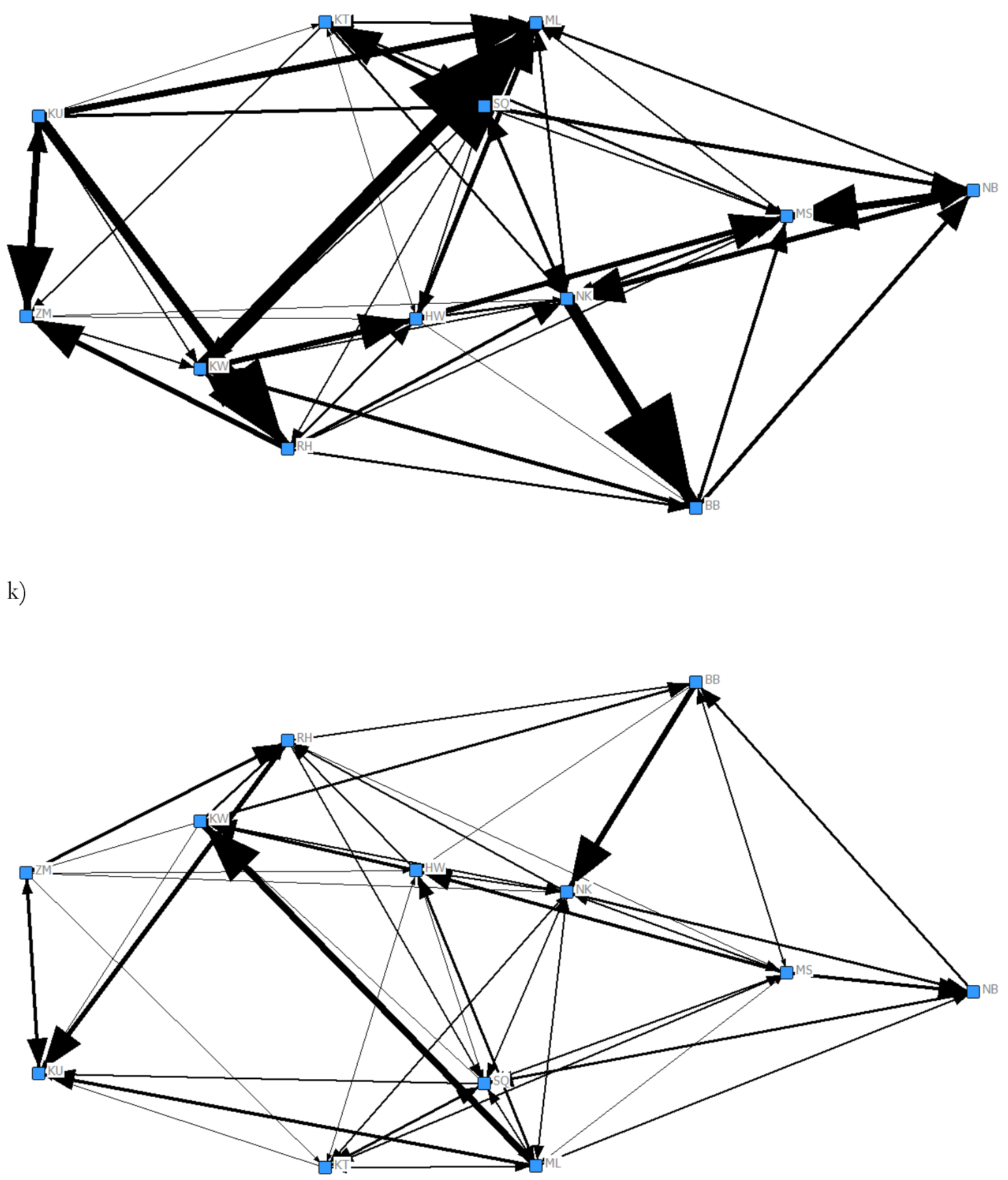

892 Figure 2. Social networks of gestures categorised according to Modality: a) auditory long range,

893 b) auditory short range, c) tactile, d) visual; e) Repertoire size; Object use: f) objects, g) no 
a)

899

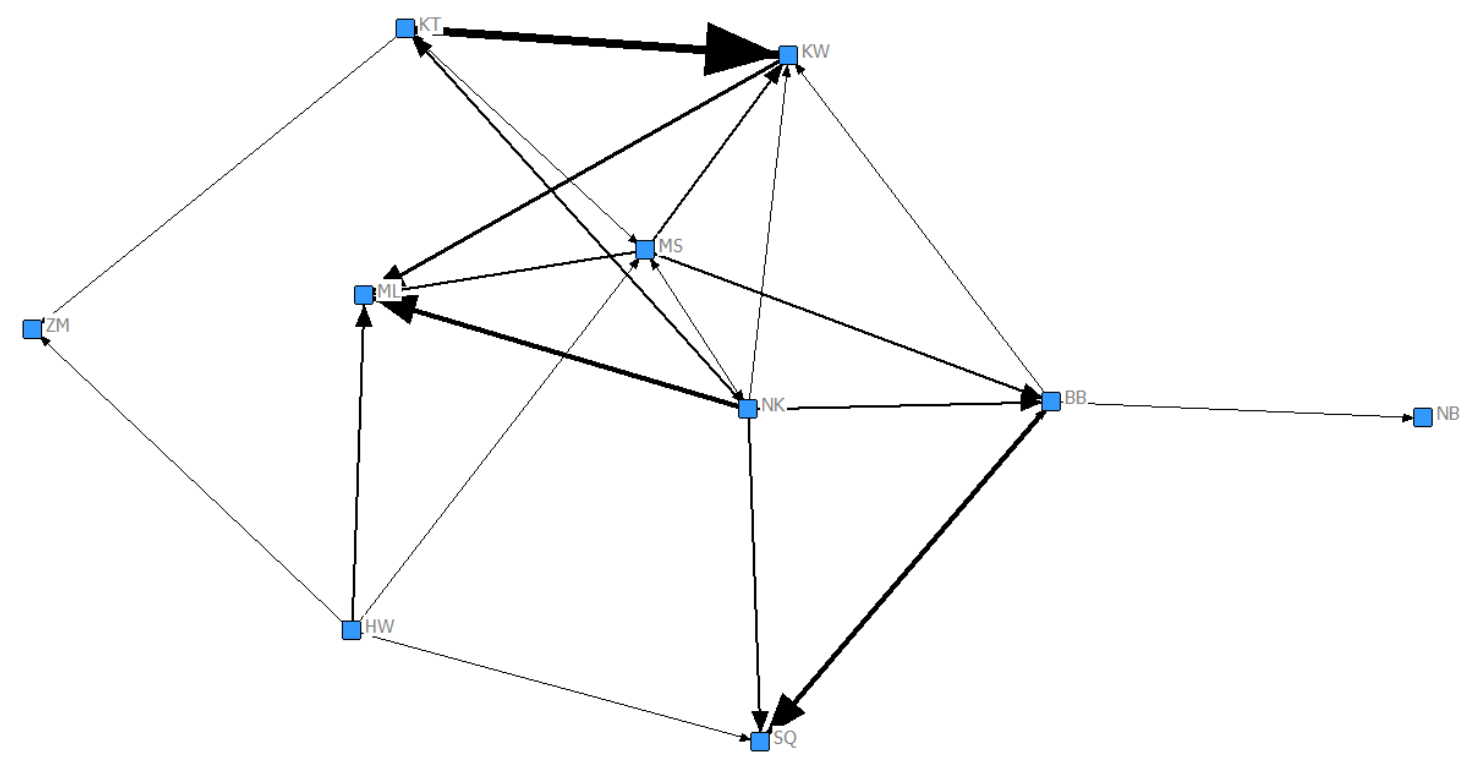

900

901

b)

902

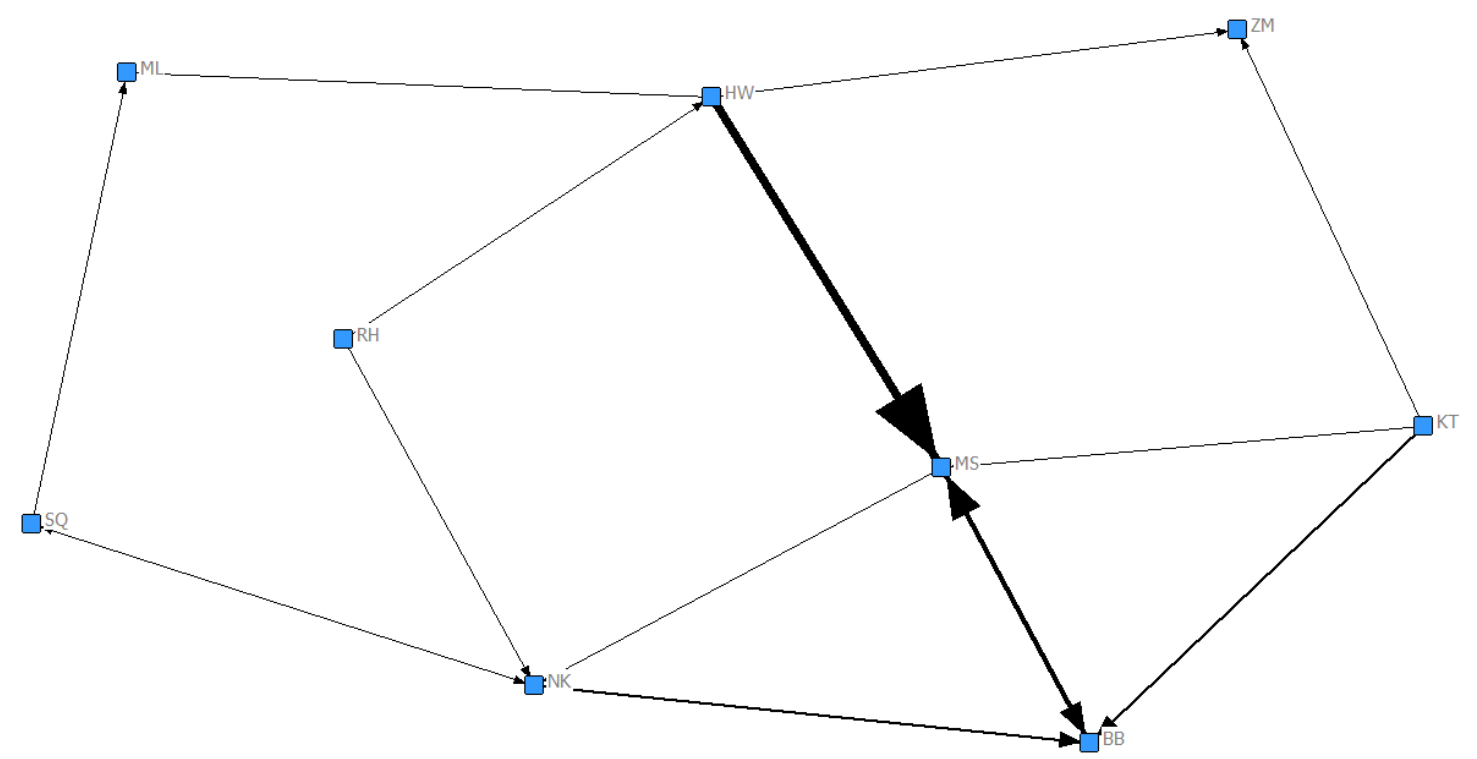

c) 


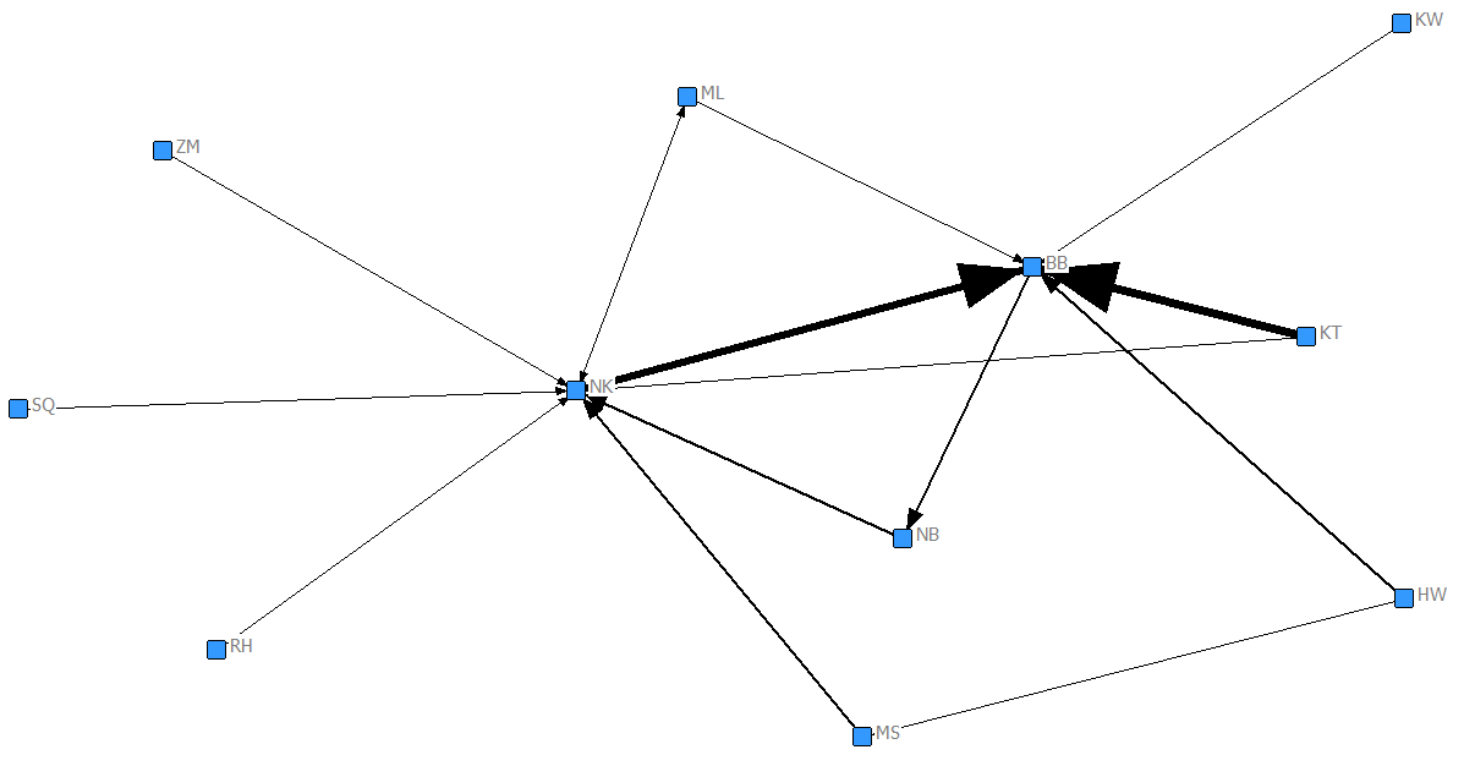

d)

906

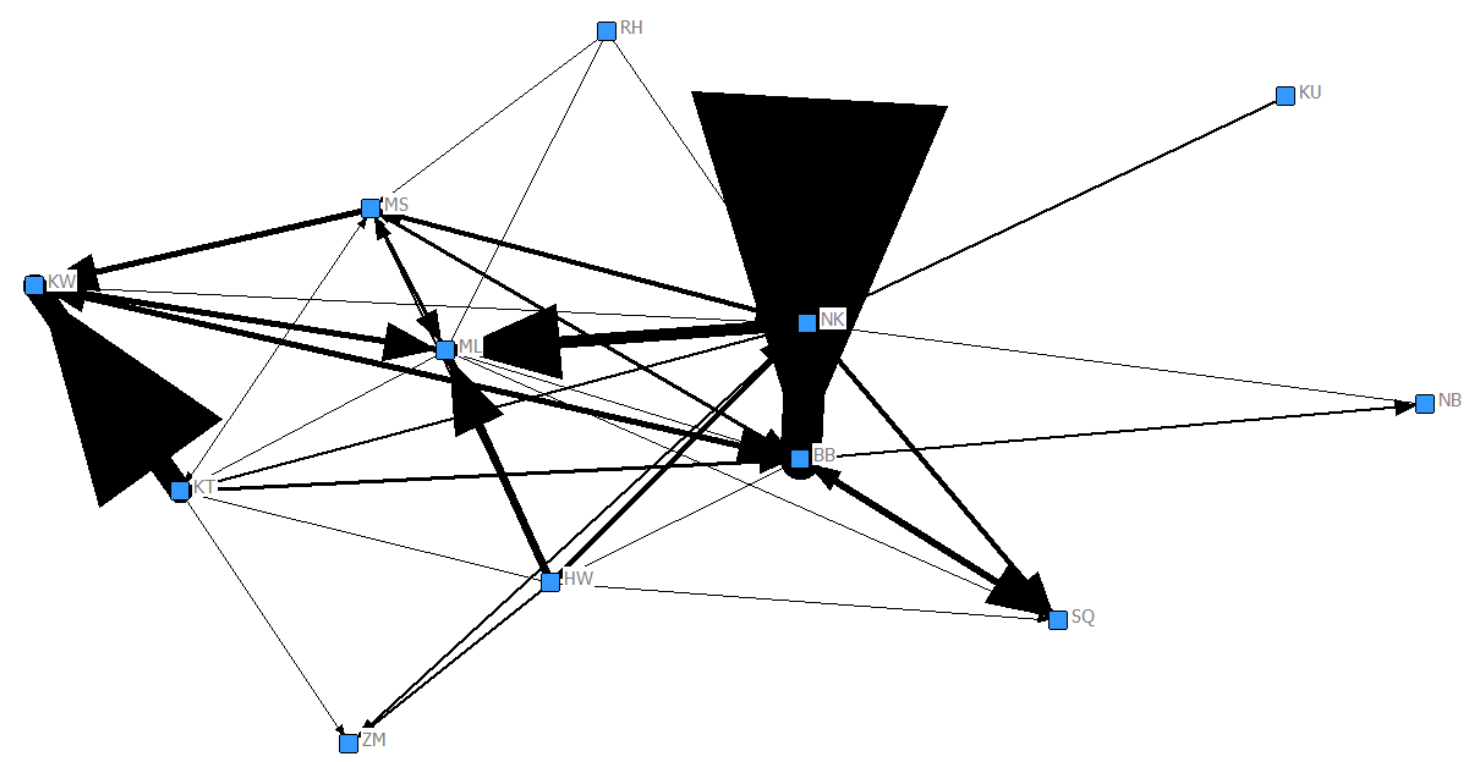



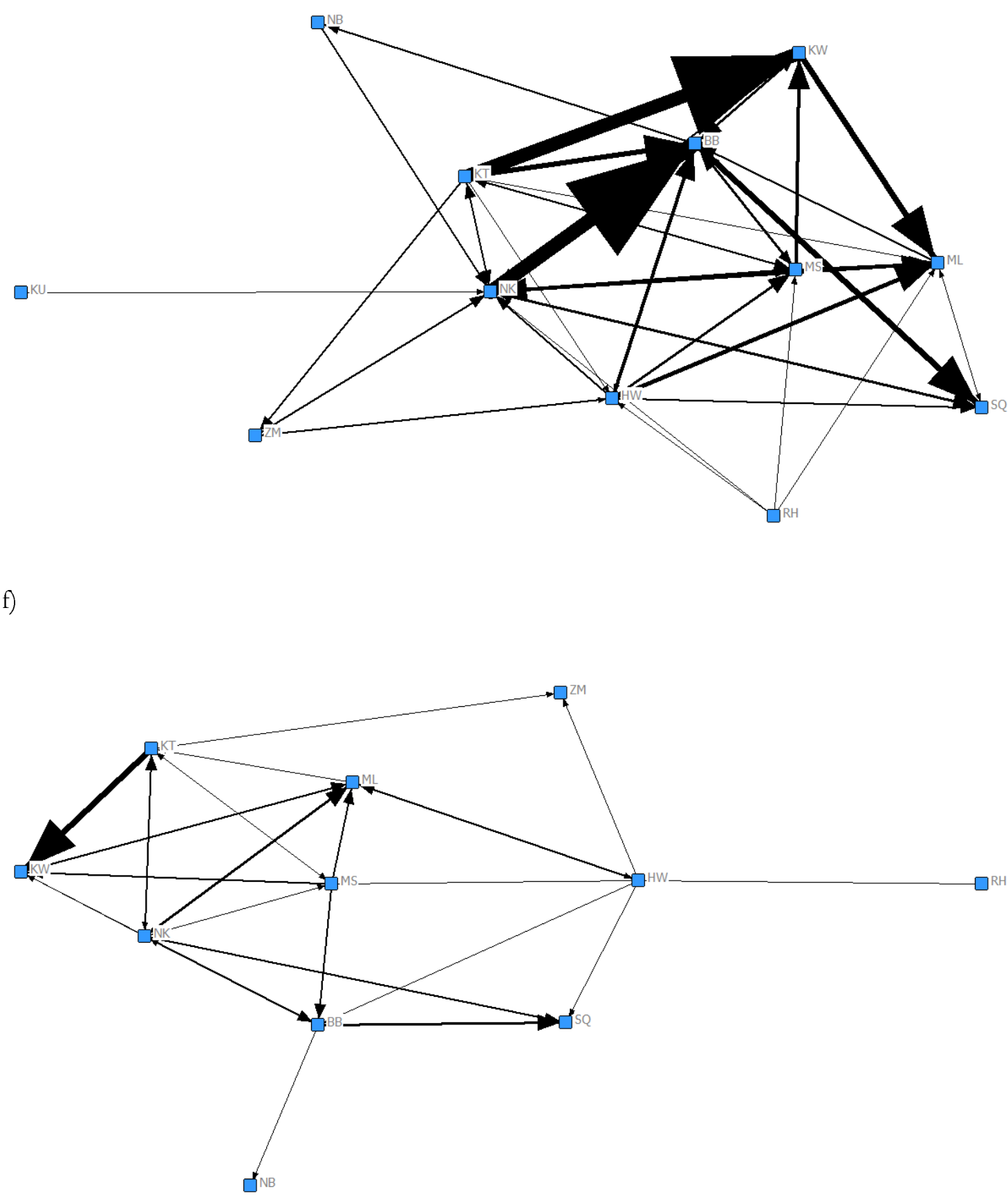


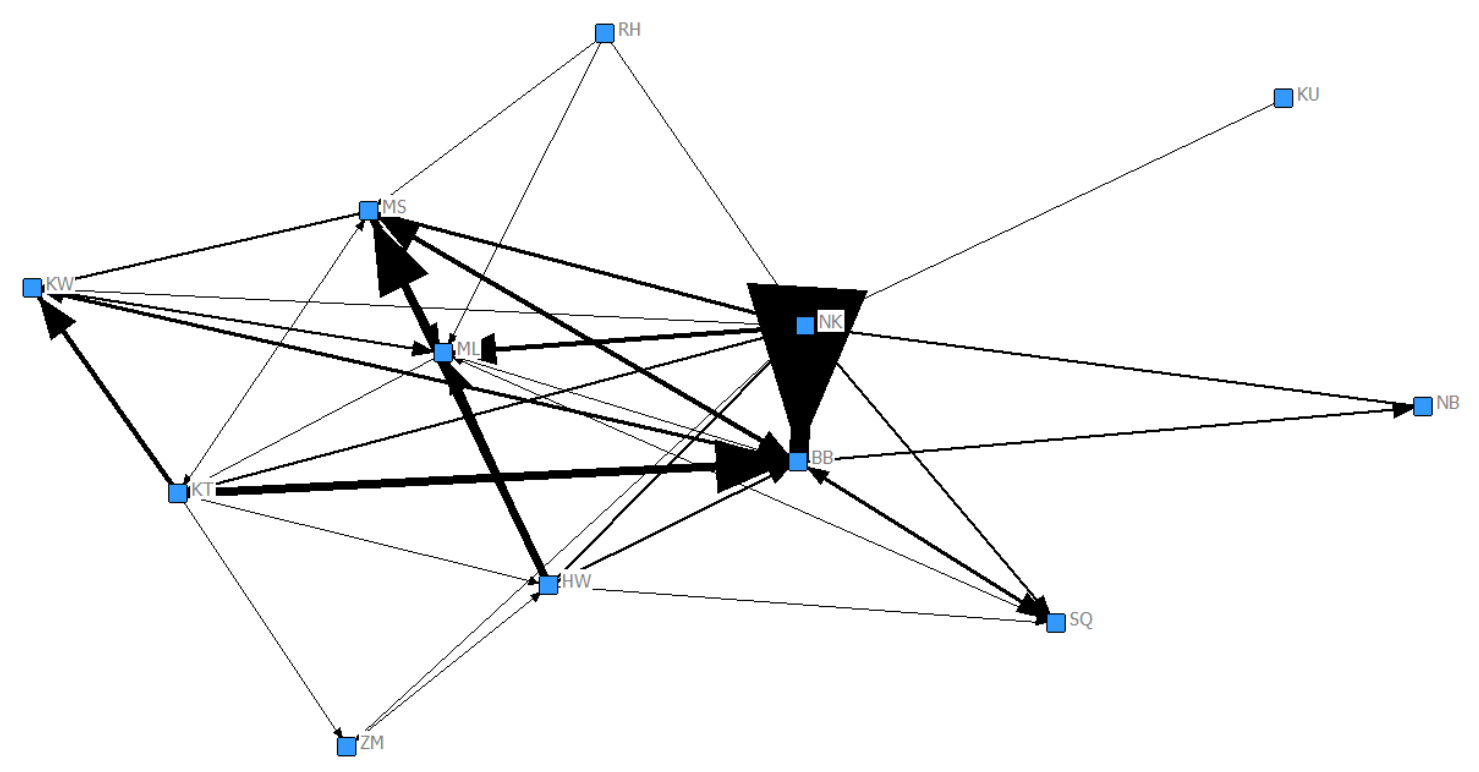

$913 \mathrm{~h})$

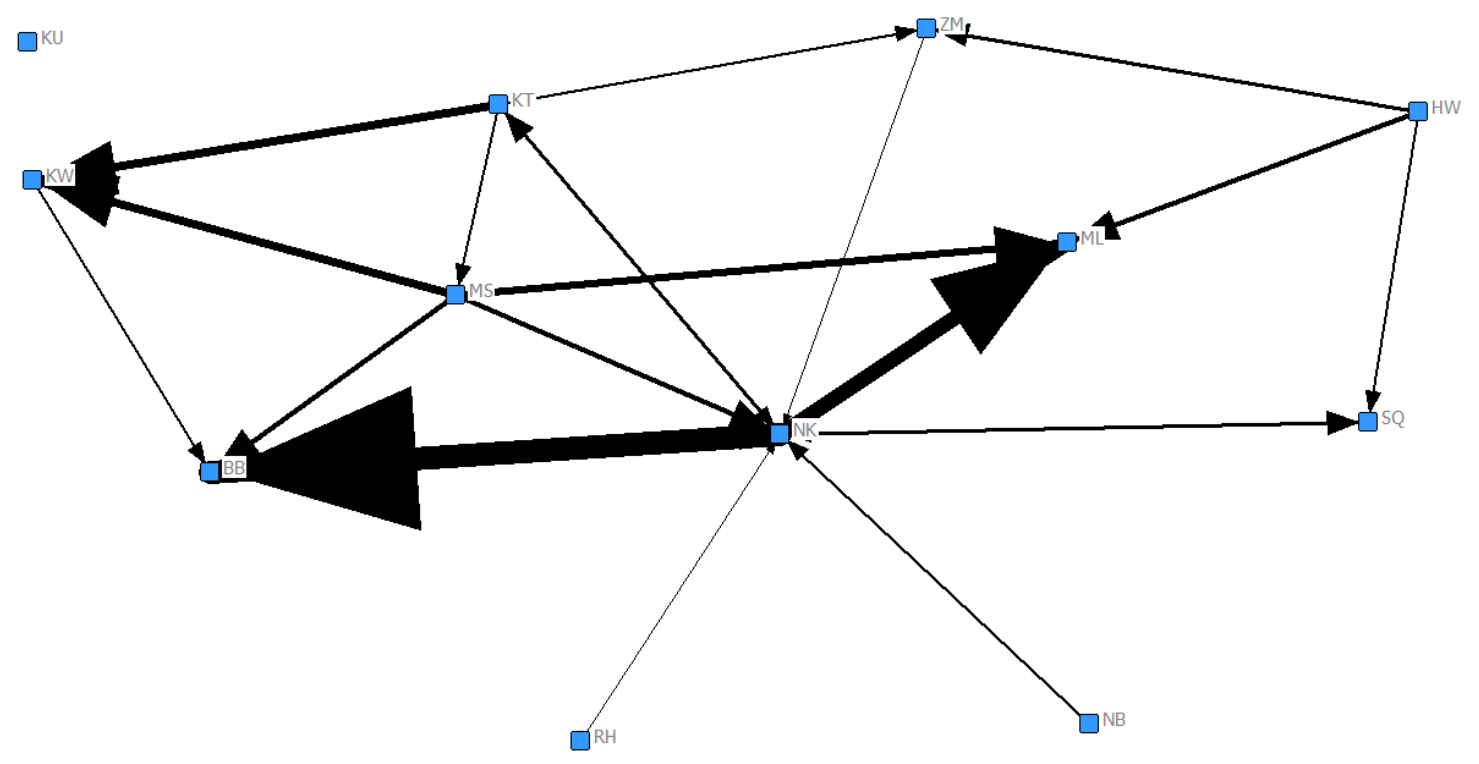



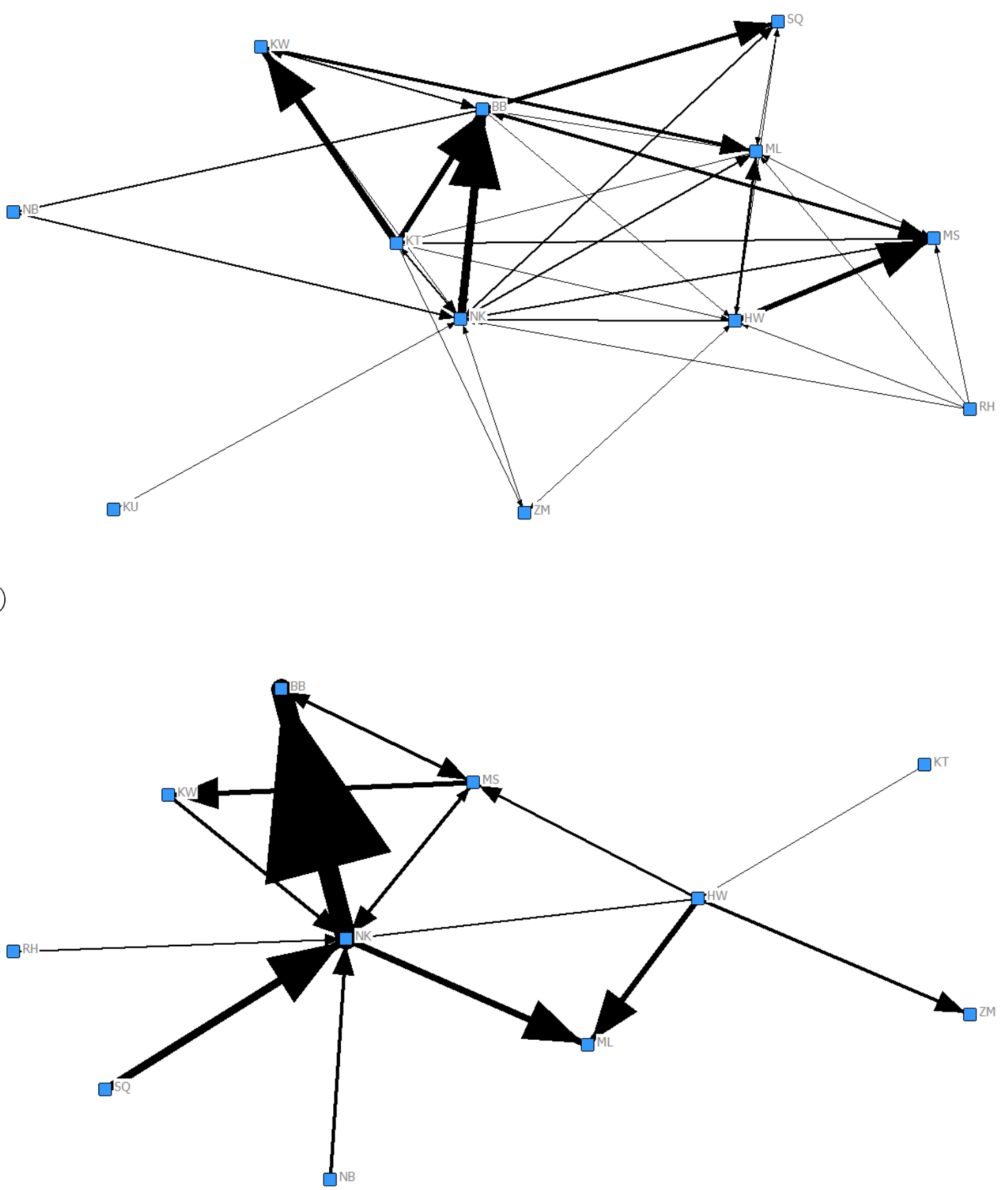

$920 \mathrm{k})$ 


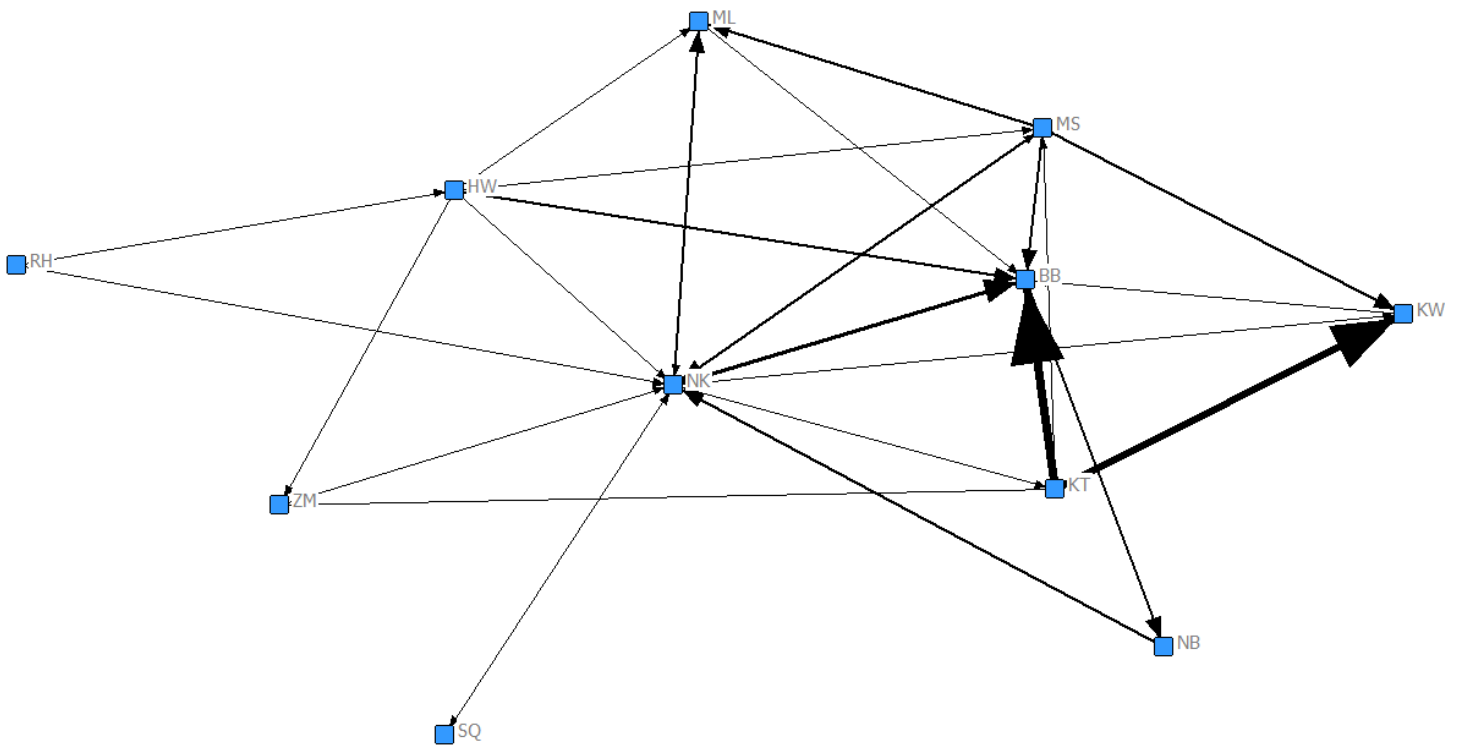

$9221)$

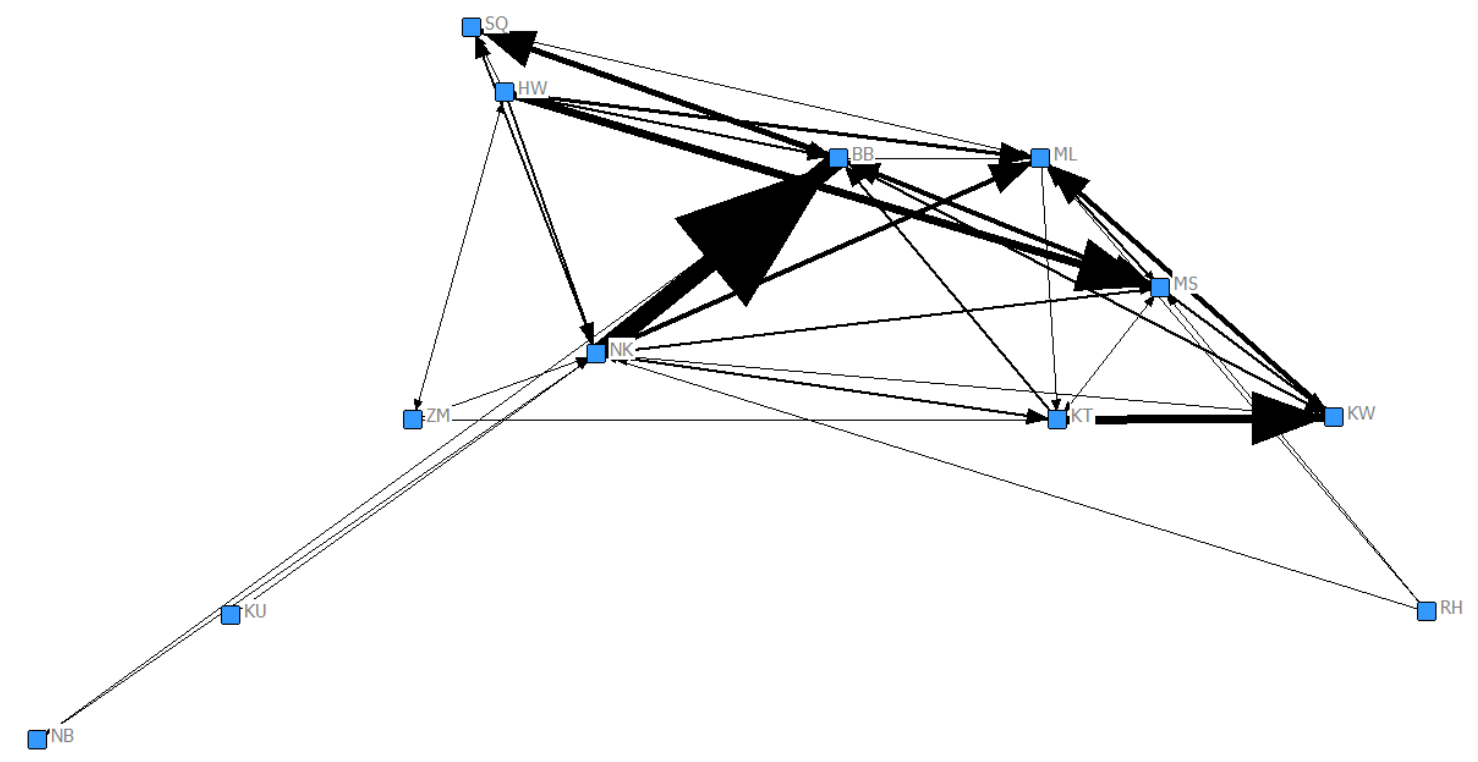




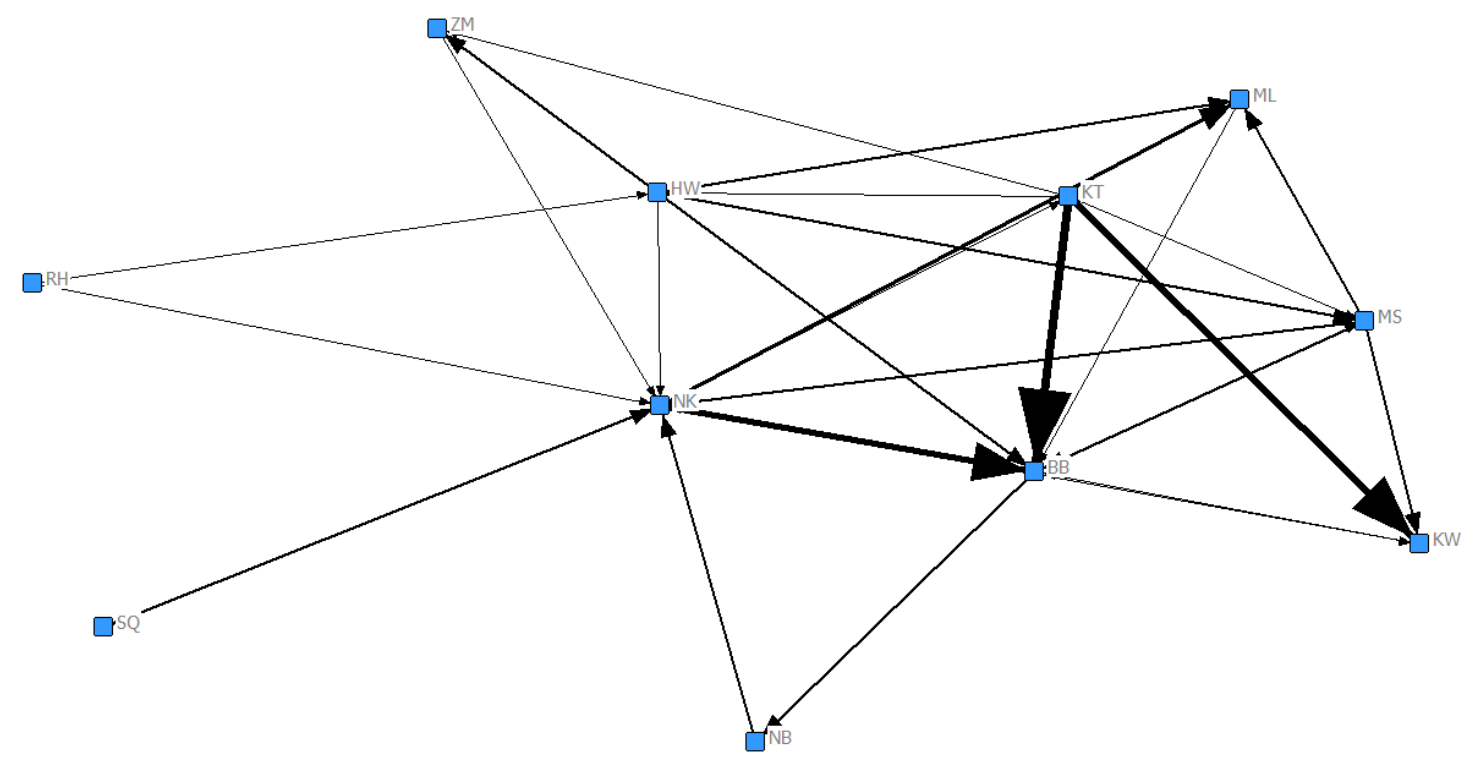

927 n)

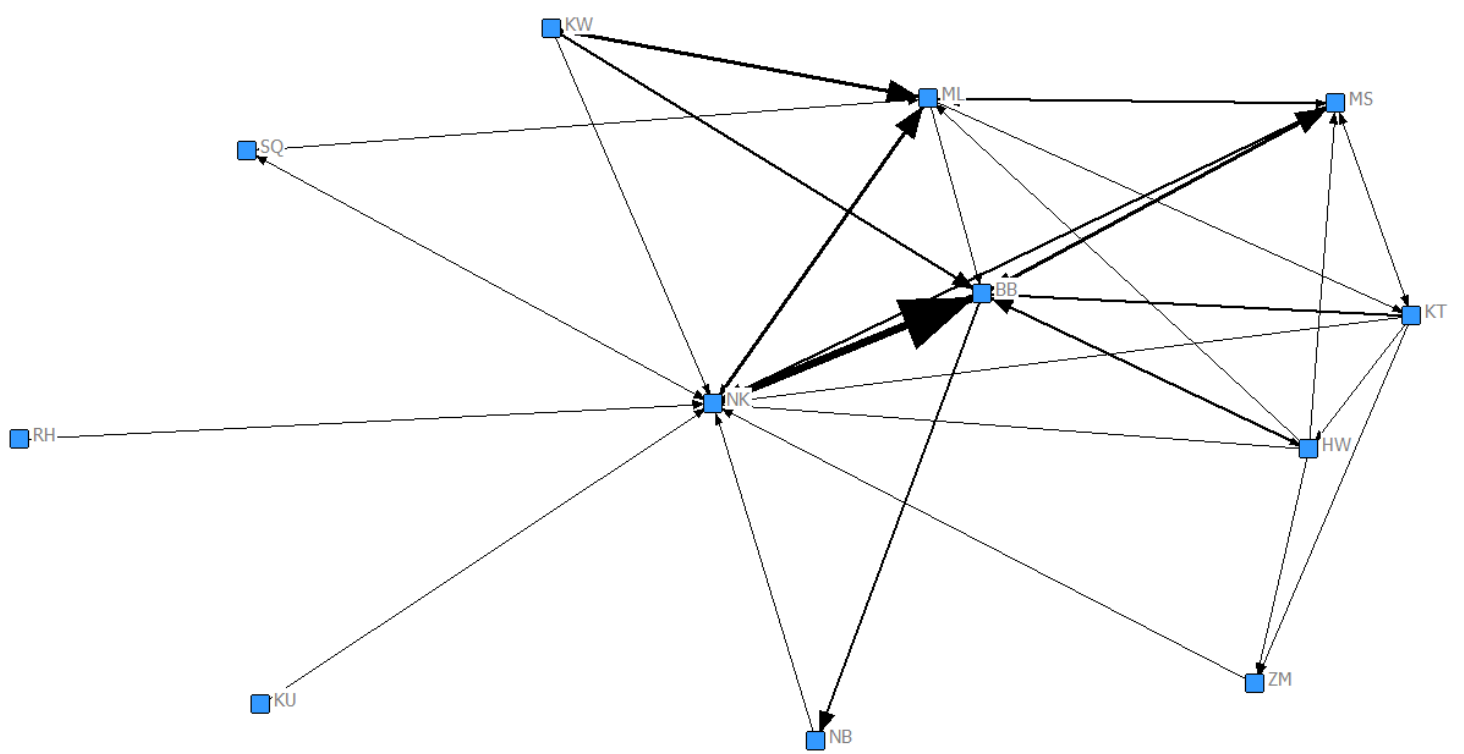

o) 


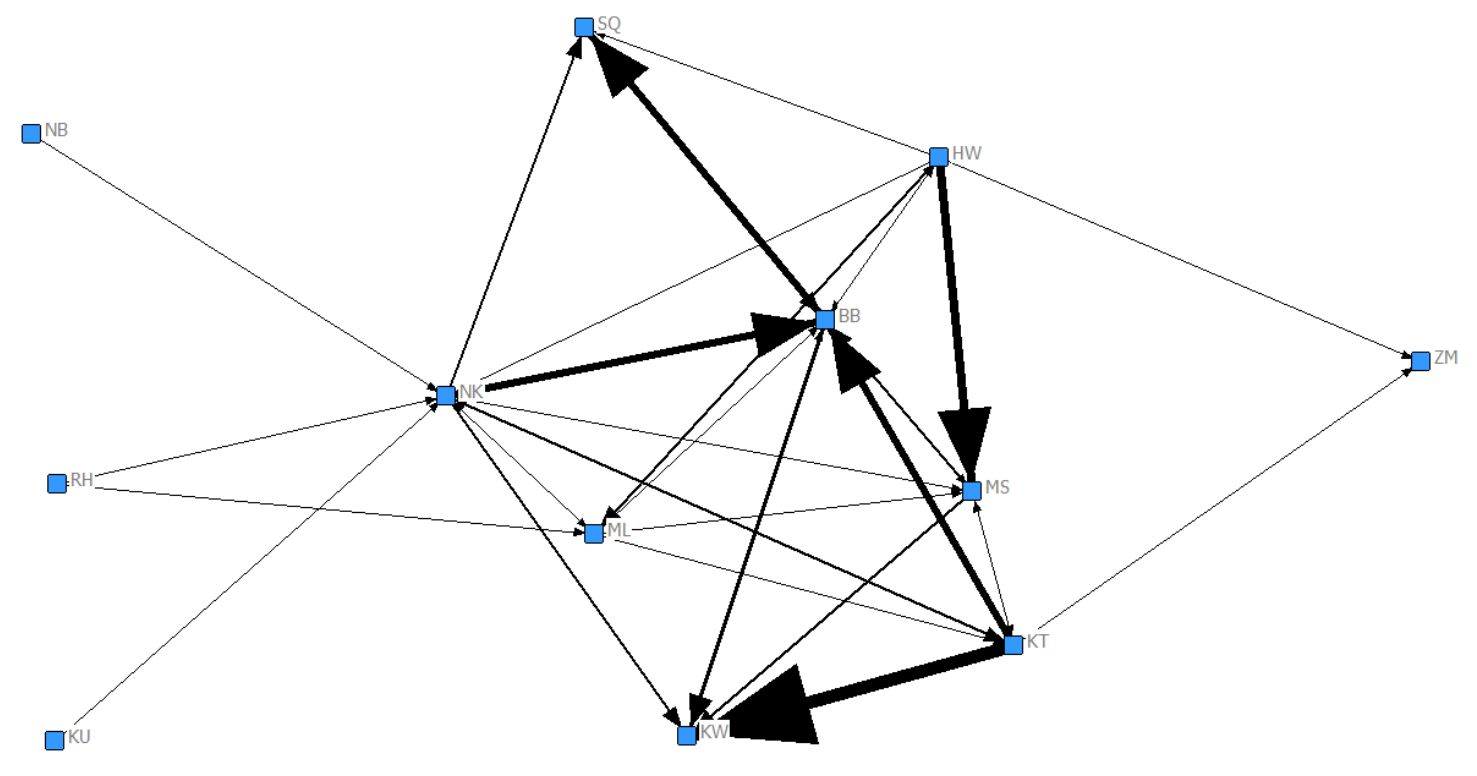

p)

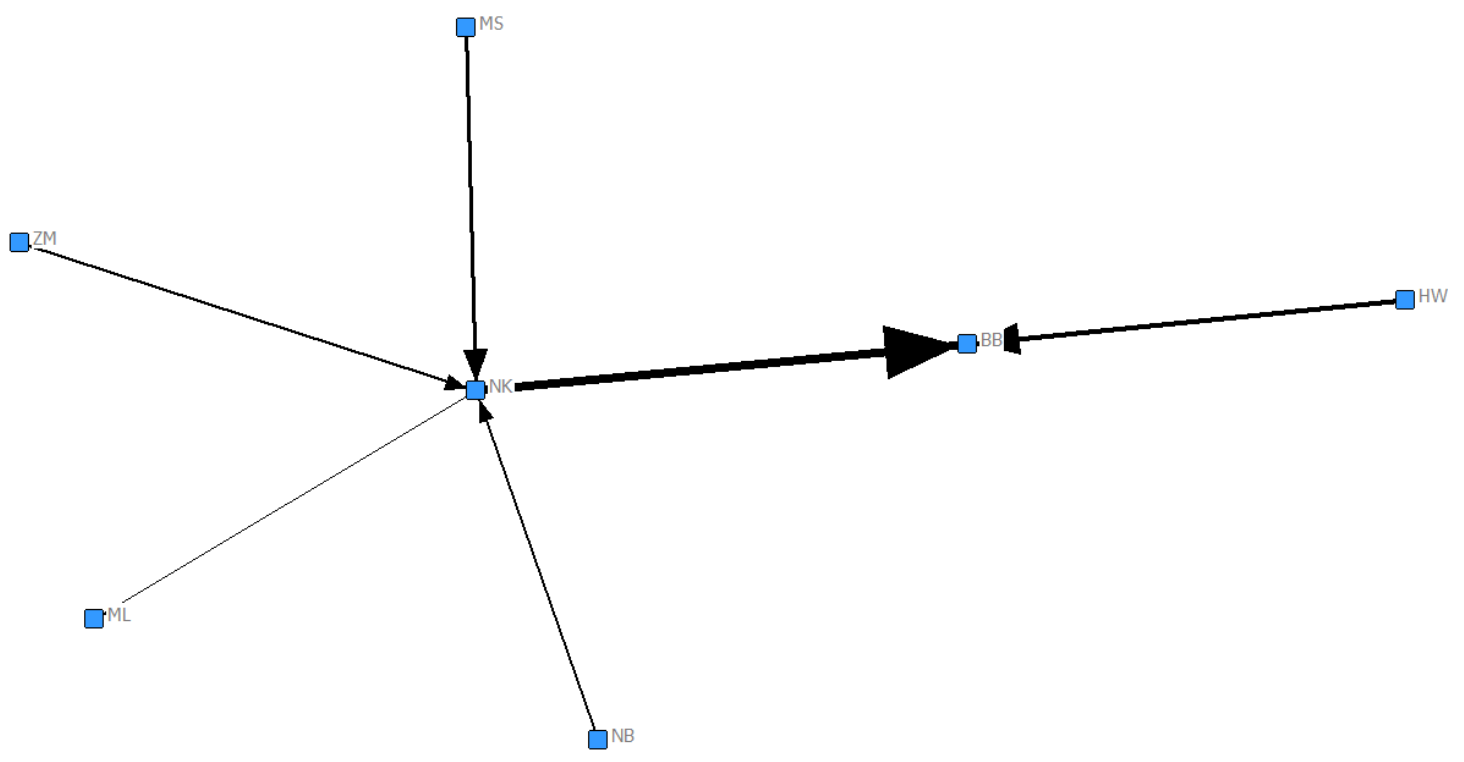

933 q) 


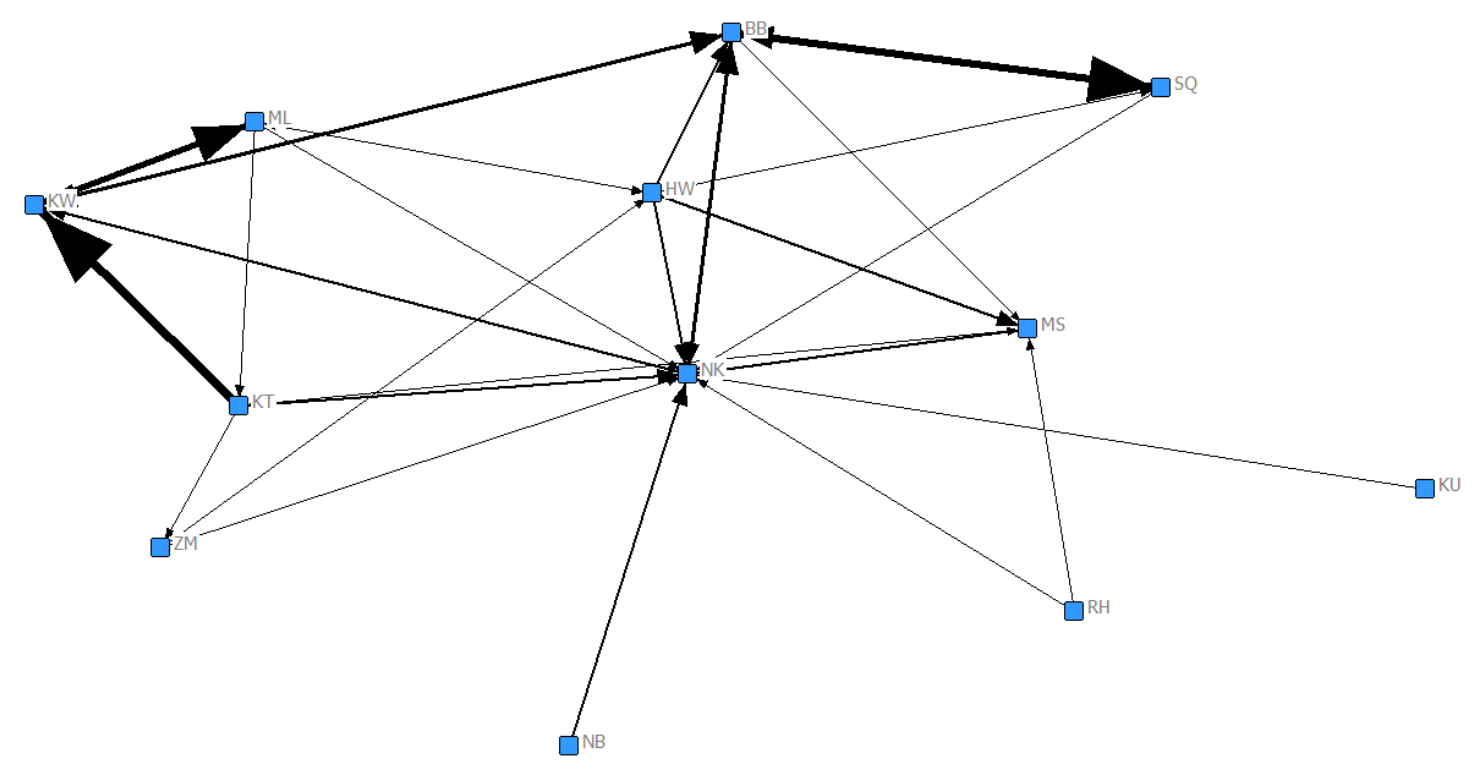

935 r)

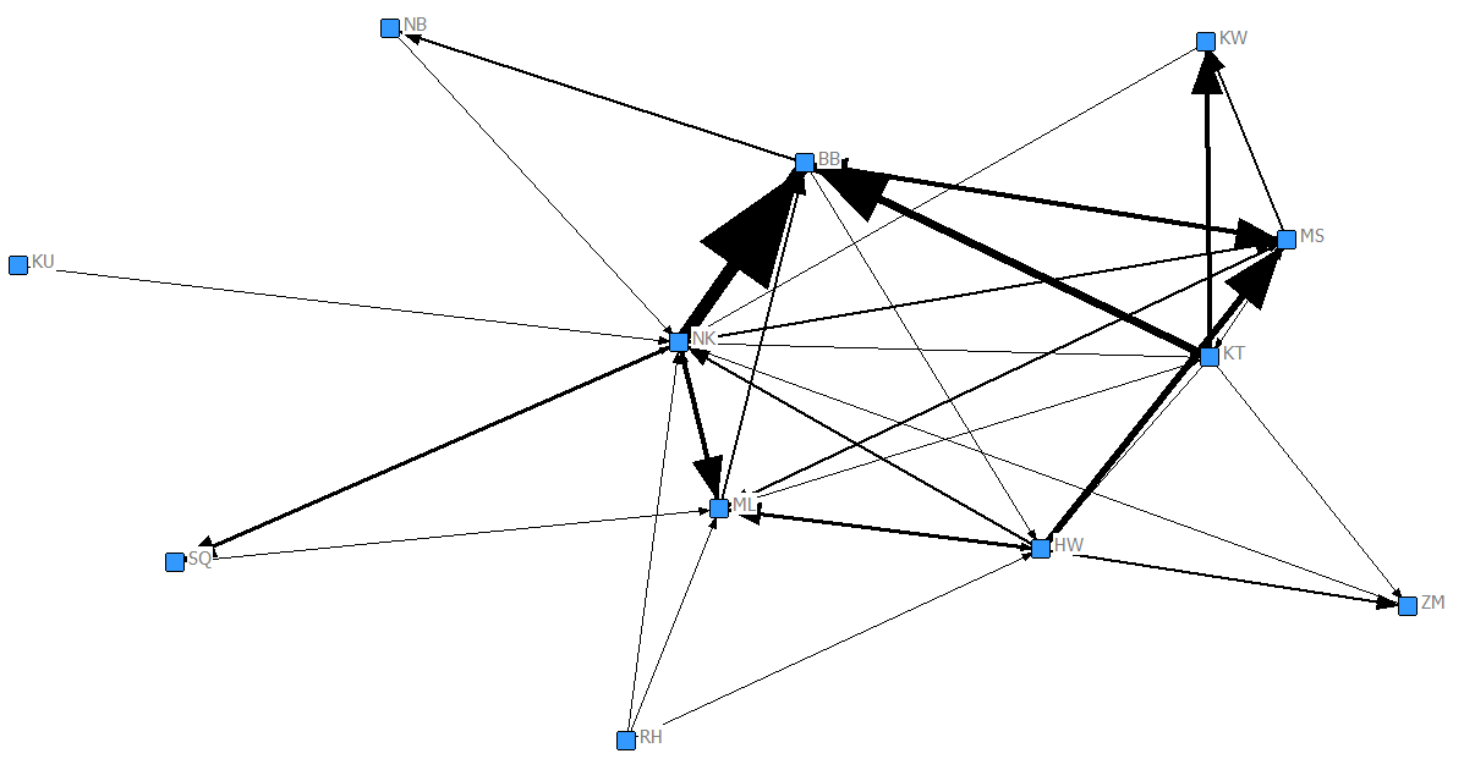



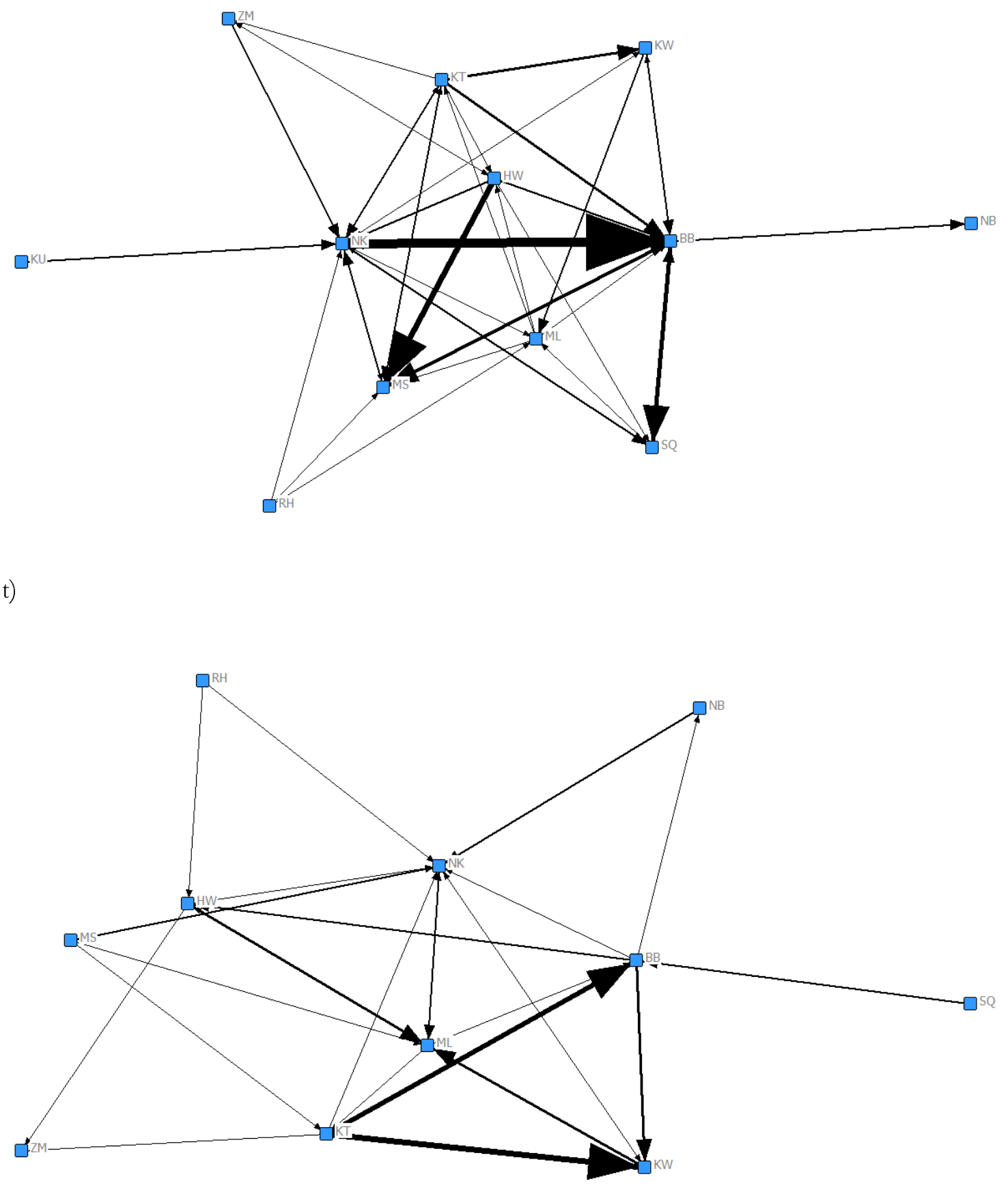


\section{Supplementary Information 1}

\section{Social bonding, gestural complexity and displacement behaviour of wild chimpanzee}

Table S1. Definitions, means and standard deviations (SD) for different types of gestural communication. Data based on gestural communication between 132 chimpanzee dyads. All gestural communication measured as the rate per hour dyad spent within $10 \mathrm{~m}$. For detailed description of all gesture types and accompanying video footage see [Roberts et al. , 2014].

\begin{tabular}{|c|c|c|c|}
\hline Gesture & Definition & Mean & SD \\
\hline $\begin{array}{l}\text { Gesture with } \\
\text { no object }\end{array}$ & Gesture is produced not using object & 2.56 & 7.14 \\
\hline $\begin{array}{l}\text { Gesture with } \\
\text { object }\end{array}$ & $\begin{array}{l}\text { Gesture is produced using object (e.g. shake branch) } \\
\text { [Nishida et al. , 2010] }\end{array}$ & 0.88 & 3.12 \\
\hline Visual gesture & $\begin{array}{l}\text { Perception of gesture is only possible by looking at the } \\
\text { signaller }\end{array}$ & 1.97 & 5.54 \\
\hline $\begin{array}{l}\text { Auditory } \\
\text { short-range } \\
\text { gesture }\end{array}$ & $\begin{array}{l}\text { Sounds produced by the gesture can be heard within } 10 \\
\mathrm{~m} \text { of the signaller }\end{array}$ & 0.41 & 2.33 \\
\hline $\begin{array}{l}\text { Auditory long- } \\
\text { range gesture }\end{array}$ & $\begin{array}{l}\text { Sounds produced by the gesture can be heard over } 10 \mathrm{~m} \\
\text { from the signaller }\end{array}$ & 0.67 & 2.30 \\
\hline Tactile gesture & Perception of the gesture is possible via physical contact & 0.44 & 2.43 \\
\hline $\begin{array}{l}\text { Unimodal } \\
\text { gesture }\end{array}$ & $\begin{array}{l}\text { Gesture does not include accompanying facial } \\
\text { expression or vocalization }\end{array}$ & 1.79 & 5.81 \\
\hline Multimodal & Gesture accompanied by simultaneous production of & 0.09 & 0.52 \\
\hline
\end{tabular}




\begin{tabular}{|c|c|c|c|}
\hline $\begin{array}{l}\text { gesture (facial } \\
\text { expression) }\end{array}$ & facial expression & & \\
\hline $\begin{array}{l}\text { Mulitmodal } \\
\text { gesture } \\
\text { (vocalization) }\end{array}$ & $\begin{array}{l}\text { A vocalization is produced whilst the signaller is } \\
\text { gesturing }\end{array}$ & 1.15 & 3.44 \\
\hline $\begin{array}{l}\text { Dyadic } \\
\text { repertoire size }\end{array}$ & $\begin{array}{l}\text { The number of gesture types produced towards the dyad } \\
\text { partner, per hour spent within } 10 \mathrm{~m}\end{array}$ & 1.97 & 5.11 \\
\hline Single gesture & A single gesture is produced by the signaller & 2.47 & 6.60 \\
\hline $\begin{array}{l}\text { Combined } \\
\text { gesture }\end{array}$ & $\begin{array}{l}\text { Two or more of different gesture types are produced } \\
\text { simultaneously by the signaller (e.g. embrace full and } \\
\text { thrust) [Nishida et al. , 2010] }\end{array}$ & 0.46 & 1.70 \\
\hline $\begin{array}{l}\text { Gesture with } \\
\text { mutual } \\
\text { attention } \\
\text { absent }\end{array}$ & $\begin{array}{l}\text { Gesture is not accompanied by simultaneous presence of } \\
\text { mutual bodily orientation between signaller and the } \\
\text { recipient. Mutual bodily orientation is when signaller's } \\
\text { and recipient's body are within each other's field of } \\
\text { view (up to } 45 \text { degrees body turn) }\end{array}$ & 0.78 & 3.39 \\
\hline $\begin{array}{l}\text { Gesture with } \\
\text { mutual } \\
\text { attention } \\
\text { present }\end{array}$ & $\begin{array}{l}\text { Gesture is accompanied by simultaneous presence of } \\
\text { mutual bodily orientation between signaller and the } \\
\text { recipient. }\end{array}$ & 1.23 & 4.15 \\
\hline Bodily & $\begin{array}{l}\text { A gesture is produced by the signaller with the part of } \\
\text { the body (e.g. head, legs, torso) that does not involve }\end{array}$ & 2.52 & 6.80 \\
\hline
\end{tabular}




\begin{tabular}{|c|c|c|c|}
\hline & use of hands & & \\
\hline Manual & A gesture is made exclusively with the hand & 0.93 & 3.19 \\
\hline Events & $\begin{array}{l}\text { Number of consecutive gesture events in the sequence } \\
\text { whereby gestures are made in quick succession with or } \\
\text { without pauses for response waiting. One gesture event } \\
\text { can contain gestures combined or not combined with } \\
\text { other gestures (e.g. embrace full and thrust co-occurring } \\
\text { would be counted as one event) [Nishida et al. , 2010] }\end{array}$ & 3.18 & 7.82 \\
\hline $\begin{array}{l}\text { Manual } \\
\text { indicative }\end{array}$ & $\begin{array}{l}\text { Movement of the arm and hand towards the recipient, } \\
\text { without physical touch or contact with substrate }\end{array}$ & 0.14 & 0.54 \\
\hline $\begin{array}{l}\text { Manual non- } \\
\text { indicative }\end{array}$ & $\begin{array}{l}\text { Movement of the arm and hand that involves physical } \\
\text { touch or contact with the substrate or visual but does not } \\
\text { involve movement of the hand towards the recipient }\end{array}$ & 0.80 & 3.01 \\
\hline Close & $\begin{array}{l}\text { Signaler produced a gesture within } 1 \text { meter from the } \\
\text { recipient }\end{array}$ & 1.09 & 4.40 \\
\hline Far & $\begin{array}{l}\text { Signaler produced a gesture from above } 1 \text { meter away } \\
\text { from the recipient }\end{array}$ & 1.64 & 5.03 \\
\hline Non-repetitive & $\begin{array}{l}\text { A gesture that does not involve repetition of movement } \\
\text { in regular and cyclical fashion such as static } \\
\text { presentation of a torso for grooming }\end{array}$ & 1.82 & 5.72 \\
\hline Repetitive & $\begin{array}{l}\text { A gesture involves repetition of movement in regular } \\
\text { and cyclical fashion in predictable manner that indicates }\end{array}$ & 1.69 & 4.80 \\
\hline
\end{tabular}




\begin{tabular}{|c|c|c|c|}
\hline & that the movement forms part of one gesture & & \\
\hline Heterogeneous & $\begin{array}{l}\text { Gesture type occurs only in signaller's repertoire of } \\
\text { gestures }\end{array}$ & 0.72 & 2.64 \\
\hline Homogeneous & $\begin{array}{l}\text { Gesture type is present in both signaller's and } \\
\text { recipient's repertoire of gestures }\end{array}$ & 1.76 & 5.49 \\
\hline $\begin{array}{l}\text { Single no } \\
\text { sequence }\end{array}$ & $\begin{array}{l}\text { A single gesture that is not made in series and where } \\
\text { there is at least } 30 \text { seconds to the next consecutive } \\
\text { gesture [Hobaiter and Byrne, 2011] }\end{array}$ & 1.27 & 4.07 \\
\hline $\begin{array}{l}\text { Rapid } \\
\text { sequence }\end{array}$ & $\begin{array}{l}\text { A series of gestures without pauses between consecutive } \\
\text { gestures [Hobaiter and Byrne, 2011] }\end{array}$ & 0.45 & 1.30 \\
\hline $\begin{array}{l}\text { Persistence } \\
\text { sequence }\end{array}$ & $\begin{array}{l}\text { A series of gestures whereby there are pauses of up to } 5 \\
\text { seconds between consecutive gestures [Hobaiter and } \\
\text { Byrne, 2011] }\end{array}$ & 0.11 & 0.45 \\
\hline Penile erection & $\begin{array}{l}\text { Production of a gesture is accompanied by simultaneous } \\
\text { erection of the penis by the signaller }\end{array}$ & 0.19 & 0.99 \\
\hline Piloerection & $\begin{array}{l}\text { Production of a gesture is accompanied by simultaneous } \\
\text { involuntary erection of hairs }\end{array}$ & 1.21 & 5.11 \\
\hline $\begin{array}{l}\text { Threat to } \\
\text { dominate }\end{array}$ & $\begin{array}{l}\text { Aggressive context with or without physical contact, } \\
\text { where there is no tangible reason for conflict of interest } \\
\text { but the recipient reacts with fear (e.g. screams) }\end{array}$ & 0.07 & 0.66 \\
\hline Food sharing & $\begin{array}{l}\text { Context where food is in recipient's possession and in } \\
\text { view of the signaller who makes successful or }\end{array}$ & 0.002 & 0.031 \\
\hline
\end{tabular}




\begin{tabular}{|c|c|c|c|}
\hline & $\begin{array}{l}\text { unsuccessful gestures in anticipation of receiving food } \\
\text { item, e.g. beg with hand [Nishida et al. , 2010] }\end{array}$ & & \\
\hline Other threat & $\begin{array}{l}\text { Communication motivated by clear conflict of interest, } \\
\text { whereby there is aggression over the resource such as } \\
\text { food or behavior such as attempt at mating. }\end{array}$ & 0.07 & 0.36 \\
\hline Travel & $\begin{array}{l}\text { Gestures made prior or during travel, which are } \\
\text { followed by the recipient relocating together with the } \\
\text { signaller, from one location in the habitat to the next. }\end{array}$ & 0.03 & 0.33 \\
\hline Copulation & $\begin{array}{l}\text { Gestures produced by a male or a tumescent female in } \\
\text { order to initiate the approach for copulation. }\end{array}$ & 0.14 & 0.79 \\
\hline Reassurance & $\begin{array}{l}\text { Gestures produced in reaction to recipient's distress, } \\
\text { fright or hurt by the signallers own behaviour or third } \\
\text { party threat. }\end{array}$ & 0.08 & 0.87 \\
\hline Greeting & $\begin{array}{l}\text { Gestures made in any of the following contexts: } \\
\text { approaching, being approached or leaving approach } \\
\text { with the individual who is non-threatening or when the } \\
\text { recipient or third party distressed, frightened or hurt the } \\
\text { signaller. }\end{array}$ & 0.27 & 0.74 \\
\hline Mutual groom & $\begin{array}{l}\text { Gestures made to initiate simultaneous grooming } \\
\text { between signaller and the recipient. }\end{array}$ & 0.07 & 0.66 \\
\hline Receive groom & $\begin{array}{l}\text { Gestures made to solicit grooming of the signaller by } \\
\text { the recipient. }\end{array}$ & 0.19 & 0.80 \\
\hline
\end{tabular}




\begin{tabular}{|c|c|c|c|}
\hline Give groom & $\begin{array}{l}\text { Gestures made to initiate grooming of the recipient by } \\
\text { the signaller. }\end{array}$ & 0.37 & 1.94 \\
\hline Play & $\begin{array}{l}\text { Gestures which initiate bouts of wrestling, chasing, } \\
\text { tickling in non-agonistic relaxed manner accompanied } \\
\text { by play-face. }\end{array}$ & 0.17 & 1.99 \\
\hline $\begin{array}{l}\text { Synchronized } \\
\text { low-intensity } \\
\text { panthoot }\end{array}$ & $\begin{array}{l}\text { Pant-hoot call produced jointly with other group } \\
\text { members and accompanied by simultaneous production } \\
\text { of visual gestures, which can be perceived only by } \\
\text { looking at signaller. }\end{array}$ & 0.05 & 0.36 \\
\hline $\begin{array}{l}\text { Solo high- } \\
\text { intensity } \\
\text { panthoot }\end{array}$ & $\begin{array}{l}\text { Pant-hoot call produced solo (without joining in by } \\
\text { other group members) and accompanied by } \\
\text { simultaneous production of auditory gestures, which } \\
\text { produce sounds audible at a distance of at least } 10 \\
\text { meters independently of the acoustic properties of the } \\
\text { pant-hoot call. If both visual and auditory gestures } \\
\text { simultaneously accompanied the pant-hoot call within } \\
\text { the same sequence it was scored as high-intensity. }\end{array}$ & 0.08 & 0.47 \\
\hline $\begin{array}{l}\text { Synchronized } \\
\text { high-intensity } \\
\text { panthoot }\end{array}$ & $\begin{array}{l}\text { Pant-hoot call plus simultaneous production of auditory } \\
\text { gestures such as drumming. Vocalisation is produced } \\
\text { jointly with other group members. }\end{array}$ & 0.20 & 1.0 \\
\hline
\end{tabular}

Table S2. Percentage of indicators for each behavioural categories that is significantly associated with behavioural indices of 5 domains of sociality (joint activity, grooming, visual attention, proximity and scratch). 


\begin{tabular}{|c|c|c|c|c|c|c|}
\hline Behaviour & $\begin{array}{l}\text { Number of } \\
\text { categories } \\
\text { of } \\
\text { complexity }\end{array}$ & $\begin{array}{l}\text { Joint } \\
\text { activity }\end{array}$ & Groom & Attention & Proximity & Scratch \\
\hline Demography & 4 & 41.67 & 25.00 & 37.50 & 25.00 & 25.00 \\
\hline Object use & 2 & 16.67 & 83.33 & 75.00 & 100.00 & 50.00 \\
\hline Modality & 4 & 41.67 & 75.00 & 50.00 & 75.00 & 50.00 \\
\hline Multimodal & 3 & 22.22 & 55.56 & 66.67 & 100.00 & 66.67 \\
\hline $\begin{array}{l}\text { Repertoire } \\
\text { size }\end{array}$ & 1 & 33.33 & 66.67 & 50.00 & 100.00 & $100.0 \mathrm{p} 0$ \\
\hline $\begin{array}{l}\text { Combined } \\
\text { gestures }\end{array}$ & 2 & 16.67 & 50.00 & 75.00 & 50.00 & 50.00 \\
\hline Attention & 2 & 16.67 & 50.00 & 50.00 & 100.00 & 50.00 \\
\hline $\begin{array}{l}\text { Bodily and } \\
\text { manual }\end{array}$ & 2 & 16.67 & 66.67 & 25.00 & 50.00 & 100.00 \\
\hline Events & 1 & 33.33 & 66.67 & 100.00 & 100.00 & 100.00 \\
\hline Indicative & 2 & 16.67 & 66.67 & 25.00 & 50.00 & 50.00 \\
\hline Proximity & 2 & 50.00 & 66.67 & 75.00 & 50.00 & 100.00 \\
\hline Repetitive & 2 & 16.67 & 66.67 & 25.00 & 50.00 & 50.00 \\
\hline
\end{tabular}




\begin{tabular}{|c|c|c|c|c|c|c|}
\hline Homogeneity & 2 & 16.67 & 66.67 & 75.00 & 50.00 & 50.00 \\
\hline Sequences & 3 & 33.33 & 44.44 & 33.33 & 33.33 & 33.33 \\
\hline $\begin{array}{l}\text { Penile } \\
\text { erection }\end{array}$ & 1 & 0.00 & 0.00 & 0.00 & 0.00 & 0.00 \\
\hline Piloerection & 1 & 33.33 & 33.33 & 50.00 & 100.00 & 100.00 \\
\hline Function & 14 & 16.67 & 33.33 & 39.29 & 35.71 & 10.71 \\
\hline
\end{tabular}

\section{$\underline{\text { Association between the duration of social behavior and gestural communication }}$}

\section{categorized according to structure}

\section{Demographic Factors}

Supplementary Table S3. MRQAP regression models predicting durations of social behavior, per hour dyad spent within 10m. Predictors were demographic variables. Dyads were classified as same age or different age (within 5 years), same sex or different sex, related by maternal kinship and as the same or different reproductive status (reproductively active, not reproductively active). Based on 132 dyadic relationships of the chimpanzees. Significant $p$ values are indicated in bold. $\mathrm{R}$ squared $\left(r^{2}\right)$ denotes amount of variance in the dependent variable explained by the regression model.

Table S3.1 Duration of joint feeding behaviour $\left(r^{2}=0.119\right)$

\begin{tabular}{|l|r|r|r|}
\hline & \multicolumn{1}{l|}{ Standardized } \\
& \multicolumn{1}{l|}{ coefficient } & Standard error & $p$ \\
\hline Age & -0.01 & 0.65 & 0.49 \\
\hline Sex & 0.31 & 0.69 & $\mathbf{0 . 0 0 1}$ \\
\hline
\end{tabular}




\begin{tabular}{|l|r|r|r|}
\hline Kinship & 0.29 & 1.28 & $\mathbf{0 . 0 1}$ \\
\hline Reproductive & 0.22 & & \\
status & & 0.72 & $\mathbf{0 . 0 4}$ \\
\hline
\end{tabular}

Table S3.2 Duration of joint resting behaviour $\left(r^{2}=0.070\right)$

\begin{tabular}{|c|c|c|c|}
\hline & $\begin{array}{l}\text { Standardized } \\
\text { coefficient }\end{array}$ & Standard error & $p$ \\
\hline Age & 0.29 & 1.37 & 0.003 \\
\hline Sex & -0.14 & 1.31 & 0.13 \\
\hline Kinship & -0.02 & 2.25 & 0.47 \\
\hline $\begin{array}{l}\text { Reproductive } \\
\text { status }\end{array}$ & -0.04 & 1.46 & 0.36 \\
\hline
\end{tabular}

Table S3.3 Duration of joint travelling behaviour $\left(r^{2}=0.09\right)$

\begin{tabular}{|c|c|c|c|}
\hline & $\begin{array}{l}\text { Standardized } \\
\text { coefficient }\end{array}$ & Standard error & $p$ \\
\hline Age & 0.28 & 0.42 & 0.01 \\
\hline Sex & 0.05 & 0.39 & 0.68 \\
\hline Kinship & 0.01 & 0.72 & 0.86 \\
\hline $\begin{array}{l}\text { Reproductive } \\
\text { status }\end{array}$ & 0.01 & 0.43 & 0.93 \\
\hline
\end{tabular}

Table S3.4 Duration of giving grooming $\left(r^{2}=0.07\right)$

\begin{tabular}{|l|l|l|l|}
\hline & Standardized & Standard error & $p$ \\
\hline
\end{tabular}




\begin{tabular}{|l|r|r|r|}
\hline & \multicolumn{2}{|l|}{ coefficient } & \\
\hline Age & 0.21 & 0.54 & $\mathbf{0 . 0 2}$ \\
\hline Sex & 0.11 & 0.53 & 0.18 \\
\hline Kinship & 0.10 & 0.96 & 0.12 \\
\hline Reproductive & 0.03 & & 0.42 \\
\hline status & & 0.66 & \\
\hline
\end{tabular}

Table S3.5 Duration of mutual grooming $\left(r^{2}=0.04\right)$

\begin{tabular}{|c|c|c|c|}
\hline & $\begin{array}{l}\text { Standardized } \\
\text { coefficient }\end{array}$ & Standard error & $p$ \\
\hline Age & 0.20 & 0.70 & 0.050 \\
\hline Sex & 0.02 & 0.72 & 0.49 \\
\hline Kinship & 0.02 & 1.29 & 0.29 \\
\hline $\begin{array}{l}\text { Reproductive } \\
\text { status }\end{array}$ & 0.14 & 0.87 & 0.18 \\
\hline
\end{tabular}

Table S3.6 Duration of receiving grooming $\left(r^{2}=0.03\right)$

\begin{tabular}{|c|c|c|c|}
\hline & $\begin{array}{l}\text { Standardized } \\
\text { coefficient }\end{array}$ & Standard error & $p$ \\
\hline Age & -0.09 & 0.48 & 0.18 \\
\hline Sex & 0.20 & 0.51 & 0.03 \\
\hline Kinship & -0.01 & 0.88 & 0.62 \\
\hline $\begin{array}{l}\text { Reproductive } \\
\text { status }\end{array}$ & 0.08 & 0.63 & 0.28 \\
\hline
\end{tabular}


Table S3.7 Duration of visual attention towards dyad partner $\left(r^{2}=0.11\right)$

\begin{tabular}{|c|c|c|c|}
\hline & $\begin{array}{l}\text { Standardized } \\
\text { coefficient }\end{array}$ & Standard error & $p$ \\
\hline Age & 0.12 & 1.47 & 0.13 \\
\hline Sex & 0.30 & 1.55 & 0.01 \\
\hline Kinship & 0.18 & 2.62 & 0.06 \\
\hline $\begin{array}{l}\text { Reproductive } \\
\text { status }\end{array}$ & 0.28 & 2.12 & 0.04 \\
\hline
\end{tabular}

Table S3.8 Duration of visual attention away dyad partner $\left(r^{2}=0.12\right)$

\begin{tabular}{|l|l|l|l|}
\hline & $\begin{array}{l}\text { Standardized } \\
\text { coefficient }\end{array}$ & Standard error & $p$ \\
\hline Age & 0.367 & 1.730 & $\mathbf{0 . 0 0 1}$ \\
\hline Sex & -0.064 & 1.277 & 0.251 \\
\hline Kinship & 0.071 & 2.783 & 0.145 \\
\hline Reproductive & 0.041 & 1.395 & 0.370 \\
status & & & \\
\hline
\end{tabular}

Table S3.9 Duration of time in close proximity - within $2 \mathrm{~m}\left(r^{2}=0.11\right)$

\begin{tabular}{|c|c|c|c|}
\hline & $\begin{array}{l}\text { Standardized } \\
\text { coefficient }\end{array}$ & Standard error & $p$ \\
\hline Age & 0.32 & 2.50 & 0.0005 \\
\hline Sex & 0.12 & 2.49 & 0.15 \\
\hline Kinship & 0.15 & 4.39 & 0.06 \\
\hline
\end{tabular}




\begin{tabular}{|l|r|r|r|}
\hline Reproductive & 0.14 & 3.55 & 0.19 \\
\hline status & 0.19 & 3 & 0 \\
\hline
\end{tabular}

Table S3.10 Rate of scratch produced $\left(r^{2}=0.046\right)$

\begin{tabular}{|l|l|l|l|}
\hline & $\begin{array}{l}\text { Standardized } \\
\text { coefficient }\end{array}$ & Standard error & $p$ \\
\hline Age & 0.016 & 0.606 & 0.41829 \\
\hline Sex & 0.201 & 0.560 & $\mathbf{0 . 0 3 9 4 8}$ \\
\hline Kinship & 0.079 & 1.143 & 0.18341 \\
\hline Reproductive & 0.030 & 0.423 & 0.38131 \\
\hline status & & & \\
\hline
\end{tabular}

Table S3.11 Rate of scratch received $\left(r^{2}=0.046\right)$

\begin{tabular}{|l|l|l|l|}
\hline & $\begin{array}{l}\text { Standardized } \\
\text { coefficient }\end{array}$ & Standard error & $p$ \\
\hline Age & 0.02 & 0.61 & 0.42779 \\
\hline Sex & 0.20 & 0.56 & $\mathbf{0 . 0 4 3 4 8}$ \\
\hline Kinship & 0.08 & 1.14 & 0.18991 \\
\hline Reproductive & 0.03 & 0.44 & 0.37481 \\
status & & & \\
\hline
\end{tabular}

\section{Object use in gestural communication}


Supplementary Table S4. MRQAP regression models predicting durations of social behavior, per hour dyad spent within $10 \mathrm{~m}$. Predictor variables were rates of gestural communication (without objects and with objects) and demographic variables. Based on 132 chimpanzee dyads. Significant $p$ values are indicated in bold. R squared $\left(r^{2}\right)$ denotes amount of variance in the dependent variable explained by the regression model.

Table S4.1 Duration of joint feeding behaviour $\left(r^{2}=0.12\right)$

\begin{tabular}{|c|c|c|c|}
\hline & $\begin{array}{l}\text { Standardized } \\
\text { coefficient }\end{array}$ & Standard error & $p$ \\
\hline Age & -0.01 & 0.68 & 0.47 \\
\hline Sex & 0.31 & 0.70 & 0.003 \\
\hline Kinship & 0.29 & 1.35 & 0.009 \\
\hline $\begin{array}{l}\text { Reproductive } \\
\text { status }\end{array}$ & 0.22 & 0.76 & 0.047 \\
\hline Object use & -0.01 & 0.08 & 0.56 \\
\hline No object use & 0.03 & 0.04 & 0.30 \\
\hline
\end{tabular}

Table S4.2 Duration of joint resting behaviour $\left(r^{2}=0.08\right)$

\begin{tabular}{|c|c|c|c|}
\hline & $\begin{array}{l}\text { Standardized } \\
\text { coefficient }\end{array}$ & Standard error & $p$ \\
\hline Age & 0.28 & 1.45 & 0.01 \\
\hline Sex & -0.16 & 1.37 & 0.10 \\
\hline Kinship & -0.02 & 2.41 & 0.42 \\
\hline $\begin{array}{l}\text { Reproductiv } \\
\text { status }\end{array}$ & -0.05 & 1.45 & 0.35 \\
\hline Object use & -0.08 & 0.18 & 0.07 \\
\hline
\end{tabular}




\begin{tabular}{|l|r|r|r|}
\hline No object use & 0.10 & 0.08 & 0.07 \\
\hline
\end{tabular}

Table S4.3 Duration of joint travelling behaviour $\left(r^{2}=0.29\right)$

\begin{tabular}{|c|c|c|c|}
\hline & $\begin{array}{l}\text { Standardized } \\
\text { coefficient }\end{array}$ & Standard error & $p$ \\
\hline Age & 0.21 & 0.35 & 0.01 \\
\hline Sex & -0.01 & 0.32 & 0.44 \\
\hline Kinship & 0.02 & 0.58 & 0.25 \\
\hline $\begin{array}{l}\text { Reproductive } \\
\text { status }\end{array}$ & -0.01 & 0.32 & 0.46 \\
\hline Object use & -0.04 & 0.04 & 0.24 \\
\hline No object use & 0.47 & 0.02 & 0.005 \\
\hline
\end{tabular}

Table S4.4 Duration of giving grooming $\left(r^{2}=0.39\right)$

\begin{tabular}{|l|r|r|r|}
\hline & \multicolumn{2}{|l|}{ Standardized } & \multicolumn{2}{|l|}{ Standard error } & $p$ \\
\hline Age & 0.12 & 0.45 & 0.08 \\
\hline Sex & 0.02 & 0.44 & 0.41 \\
\hline Kinship & 0.10 & 0.85 & 0.08 \\
\hline Reproductive & 0.00 & 0.46 & 0.47 \\
status & -0.20 & 0.06 & $\mathbf{0 . 0 1}$ \\
\hline Object use & 0.64 & 0.04 & $\mathbf{0 . 0 0 1}$ \\
\hline No object use & & & \\
\hline
\end{tabular}

Table S4.5 Duration of mutual grooming $\left(r^{2}=0.38\right)$ 


\begin{tabular}{|c|c|c|c|}
\hline & $\begin{array}{l}\text { Standardized } \\
\text { coefficient }\end{array}$ & Standard error & $p$ \\
\hline Age & 0.11 & 0.55 & 0.10 \\
\hline Sex & -0.07 & 0.53 & 0.24 \\
\hline Kinship & 0.02 & 1.00 & 0.26 \\
\hline $\begin{array}{l}\text { Reproductive } \\
\text { status }\end{array}$ & 0.10 & 0.58 & 0.12 \\
\hline Object use & -0.15 & 0.07 & 0.02 \\
\hline No object use & 0.64 & 0.04 & 0.0005 \\
\hline
\end{tabular}

Table S4.6 Duration of receiving grooming $\left(r^{2}=0.07\right)$

\begin{tabular}{|c|c|c|c|}
\hline & $\begin{array}{l}\text { Standardized } \\
\text { coefficient }\end{array}$ & Standard error & $p$ \\
\hline Age & -0.12 & 0.49 & 0.09 \\
\hline Sex & 0.17 & 0.49 & 0.05 \\
\hline Kinship & 0.00 & 0.91 & 0.66 \\
\hline $\begin{array}{l}\text { Reproductive } \\
\text { status }\end{array}$ & 0.07 & 0.56 & 0.27 \\
\hline Object use & -0.04 & 0.06 & 0.34 \\
\hline No object use & 0.22 & 0.03 & 0.04 \\
\hline
\end{tabular}

Table S4.7 Duration of visual attention towards dyad partner $\left(r^{2}=0.49\right)$

\begin{tabular}{|l|l|l|l|}
\hline & $\begin{array}{l}\text { Standardized } \\
\text { coefficient }\end{array}$ & Standard error & $p$ \\
\hline
\end{tabular}




\begin{tabular}{|l|r|r|r|}
\hline Age & 0.02 & 1.10 & 0.39 \\
\hline Sex & 0.20 & 1.12 & $\mathbf{0 . 0 1}$ \\
\hline Kinship & 0.19 & 2.11 & $\mathbf{0 . 0 1}$ \\
\hline Reproductive & 0.24 & 1.42 & $\mathbf{0 . 0 1}$ \\
status & -0.18 & 0.14 & $\mathbf{0 . 0 0 3}$ \\
\hline Object use & 0.69 & 0.10 & $\mathbf{0 . 0 0 0 5}$ \\
\hline No object use & & & \\
\hline
\end{tabular}

Table S4.8 Duration of visual attention away from dyad partner $\left(r^{2}=0.16\right)$

\begin{tabular}{|l|l|l|l|}
\hline & Standardized & Standard error & $p$ \\
\hline Age & 0.335 & 1.671 & \\
\hline Sex & -0.083 & 1.277 & $\mathbf{0 . 0 0 2}$ \\
\hline Kinship & 0.069 & 2.892 & 0.180 \\
\hline Reproductive & 0.003 & 1.271 & 0.138 \\
\hline status & & & 0.517 \\
\hline Object use & -0.098 & 0.202 & \\
\hline No object use & 0.240 & 0.097 & 0.070 \\
\hline
\end{tabular}

Table S4.9 Duration of time in close proximity - within $2 \mathrm{~m}\left(r^{2}=0.37\right)$

\begin{tabular}{|c|c|c|c|}
\hline & $\begin{array}{l}\text { Standardized } \\
\text { coefficient }\end{array}$ & Standard error & $p$ \\
\hline Age & 0.24 & 2.05 & 0.001 \\
\hline
\end{tabular}




\begin{tabular}{|l|r|r|r|}
\hline Sex & 0.04 & 2.05 & 0.32 \\
\hline Kinship & 0.15 & 3.60 & $\mathbf{0 . 0 3}$ \\
\hline Reproductive & 0.11 & & 0.17 \\
status & -0.17 & 2.54 & $\mathbf{0 . 0 0 3}$ \\
\hline Object use & 0.56 & 0.26 & $\mathbf{0 . 0 0 0 5}$ \\
\hline No object use & & 0.15 & \\
\hline
\end{tabular}

Table S4.10 Rate of scratch produced $\left(r^{2}=0.190\right)$

\begin{tabular}{|l|l|l|l|}
\hline & Standardized & Standard error & $p$ \\
\hline Age & -0.043 & 0.591 & \\
\hline Sex & 0.175 & 0.525 & 0.35782 \\
\hline Kinship & 0.085 & 1.162 & 0.05097 \\
\hline Reproductive & -0.031 & & 0.17541 \\
status & & 0.438 & 0.33633 \\
\hline Object use & -0.016 & & \\
\hline No object use & 0.400 & 0.072 & 0.49375 \\
& & & $\mathbf{0 . 0 0 4 5}$ \\
\hline
\end{tabular}

Table S4.11 Rate of scratch received $\left(r^{2}=0.050\right)$

\begin{tabular}{|l|l|l|l|}
\hline & $\begin{array}{l}\text { Standardized } \\
\text { coefficient }\end{array}$ & Standard error & $p$ \\
\hline Age & 0.03 & 0.63 & 0.38331 \\
\hline
\end{tabular}




\begin{tabular}{|l|l|l|l|}
\hline Sex & 0.20 & 0.57 & $\mathbf{0 . 0 3 9 9 8}$ \\
\hline Kinship & 0.08 & 1.12 & 0.17841 \\
\hline Reproductive & 0.04 & 0.45 & 0.30585 \\
status & & & \\
\hline Object use & -0.01 & 0.08 & 0.56822 \\
\hline No object use & -0.06 & 0.03 & 0.26087 \\
\hline
\end{tabular}

\section{Modality of gestural communication}

Supplementary Table S5. MRQAP regression models predicting durations of social behavior, per hour dyad spent within $10 \mathrm{~m}$. Predictor variables were rates of gestural communication of different modalities (visual, tactile, auditory short-range, auditory long-range) and demographic variables. Based on 132 chimpanzee dyads. Significant $p$ values are indicated in bold. $\mathrm{R}$ squared $\left(r^{2}\right)$ denotes amount of variance in the dependent variable explained by the regression model.

Table S5.1 Duration of joint feeding behaviour $\left(r^{2}=0.17\right)$

\begin{tabular}{|c|c|c|c|}
\hline & $\begin{array}{l}\text { Standardized } \\
\text { coefficient }\end{array}$ & Standard error & $p$ \\
\hline Age & -0.07 & 0.68 & 0.27 \\
\hline Sex & 0.33 & 0.70 & 0.002 \\
\hline Kinship & 0.29 & 1.30 & 0.01 \\
\hline $\begin{array}{l}\text { Reproductive } \\
\text { status }\end{array}$ & 0.21 & 0.71 & 0.03 \\
\hline Visual gestures & 0.15 & 0.07 & 0.12 \\
\hline
\end{tabular}




\begin{tabular}{|l|r|r|r|}
\hline Auditory long- & -0.08 & 0.13 & 0.21 \\
range gestures & 0.21 & 0.11 & \\
\hline Auditory short- & -0.22 & 0.13 & $\mathbf{0 . 0 4}$ \\
range gestures & & & $\mathbf{0 . 0 0 4}$ \\
\hline Tactile gestures & & & \\
\hline
\end{tabular}

Table S5.2 Duration of joint resting behaviour $\left(r^{2}=0.09\right)$

\begin{tabular}{|c|c|c|c|}
\hline & $\begin{array}{l}\text { Standardized } \\
\text { coefficient }\end{array}$ & Standard error & $p$ \\
\hline Age & 0.26 & 1.43 & 0.01 \\
\hline Sex & -0.16 & 1.38 & 0.10 \\
\hline Kinship & -0.03 & 2.43 & 0.39 \\
\hline $\begin{array}{l}\text { Reproductive } \\
\text { status }\end{array}$ & -0.05 & 1.51 & 0.33 \\
\hline Visual gestures & 0.02 & 0.15 & 0.36 \\
\hline $\begin{array}{l}\text { Auditory long- } \\
\text { range gestures }\end{array}$ & -0.06 & 0.34 & 0.21 \\
\hline $\begin{array}{l}\text { Auditory short- } \\
\text { range gestures }\end{array}$ & 0.13 & 0.24 & 0.04 \\
\hline Tactile gestures & 0.004 & 0.29 & 0.36 \\
\hline
\end{tabular}

Table S5.3 Duration of joint travelling behaviour $\left(r^{2}=0.32\right)$

\begin{tabular}{|l|l|l|l|}
\hline & $\begin{array}{l}\text { Standardized } \\
\text { coefficient }\end{array}$ & Standard error & $p$ \\
\hline
\end{tabular}




\begin{tabular}{|l|r|r|r|}
\hline Age & 0.21 & 0.33 & $\mathbf{0 . 0 1}$ \\
\hline Sex & 0.04 & 0.30 & 0.36 \\
\hline Kinship & 0.02 & 0.58 & 0.25 \\
\hline Reproductive & 0.00 & 0.30 & 0.50 \\
status & 0.62 & 0.04 & $\mathbf{0 . 0 1}$ \\
\hline Visual gestures & -0.28 & & \\
\hline Auditory long- & & 0.08 & $\mathbf{0 . 0 1}$ \\
range gestures & 0.04 & 0.05 & 0.11 \\
\hline Auditory short- & -0.02 & 0.07 & 0.43 \\
\hline range gestures & & & \\
\hline Tactile gestures & & & \\
\hline
\end{tabular}

Table S5.4 Duration of giving grooming $\left(r^{2}=0.74\right)$

\begin{tabular}{|c|c|c|c|}
\hline & $\begin{array}{l}\text { Standardized } \\
\text { coefficient }\end{array}$ & Standard error & $p$ \\
\hline Age & 0.06 & 0.27 & 0.11 \\
\hline Sex & -0.02 & 0.27 & 0.38 \\
\hline Kinship & 0.09 & 0.47 & 0.03 \\
\hline Reproductive & & & \\
\hline status & 0.00 & 0.33 & 0.46 \\
\hline Visual gestures & -0.26 & 0.04 & 0.01 \\
\hline Auditory long- & & & \\
\hline range gestures & 0.19 & 0.08 & 0.01 \\
\hline Auditory short- & 0.73 & 0.09 & 0.0005 \\
\hline
\end{tabular}




\begin{tabular}{|l|r|r|r|}
\hline range gestures & & & \\
\hline Tactile gestures & 0.41 & 0.08 & $\mathbf{0 . 0 0 0 5}$ \\
\hline
\end{tabular}

Table S5.5 Duration of mutual grooming $\left(r^{2}=0.48\right)$

\begin{tabular}{|c|c|c|c|}
\hline & $\begin{array}{l}\text { Standardized } \\
\text { coefficient }\end{array}$ & Standard error & $p$ \\
\hline Age & 0.12 & 0.49 & 0.07 \\
\hline Sex & -0.01 & 0.49 & 0.47 \\
\hline Kinship & 0.03 & 0.87 & 0.27 \\
\hline $\begin{array}{l}\text { Reproductive } \\
\text { status }\end{array}$ & 0.12 & 0.53 & 0.08 \\
\hline Visual gestures & 0.88 & 0.07 & 0.0005 \\
\hline $\begin{array}{l}\text { Auditory long- } \\
\text { range gestures }\end{array}$ & -0.51 & 0.12 & 0.0005 \\
\hline $\begin{array}{l}\text { Auditory short- } \\
\text { range gestures }\end{array}$ & 0.01 & 0.08 & 0.25 \\
\hline Tactile gestures & -0.03 & 0.10 & 0.37 \\
\hline
\end{tabular}

Table S5.6 Duration of receiving grooming $\left(r^{2}=0.11\right)$

\begin{tabular}{|l|r|r|r|}
\hline & \multicolumn{2}{|l|}{ Standardized } \\
& \multicolumn{2}{|l|}{ Standard error } & $p$ \\
\hline Age & -0.15 & 0.50 & $\mathbf{0 . 0 4}$ \\
\hline Sex & 0.21 & 0.49 & $\mathbf{0 . 0 2}$ \\
\hline Kinship & 0.00 & 0.91 & 0.32 \\
\hline
\end{tabular}




\begin{tabular}{|l|r|r|r|}
\hline Reproductive & 0.07 & 0.56 & 0.24 \\
\hline status & 0.50 & 0.06 & $\mathbf{0 . 0 2}$ \\
\hline Visual gestures & -0.27 & 0.13 & $\mathbf{0 . 0 2}$ \\
range gestures & 0.04 & 0.08 & 0.11 \\
\hline Auditory short- & -0.20 & 0.12 & $\mathbf{0 . 0 0 0 5}$ \\
\hline range gestures & & & \\
\hline Tactile gestures & & & \\
\hline
\end{tabular}

Table S5.7 Duration of visual attention towards dyad partner $\left(r^{2}=0.21\right)$

\begin{tabular}{|c|c|c|c|}
\hline & $\begin{array}{l}\text { Standardized } \\
\text { coefficient }\end{array}$ & Standard error & $p$ \\
\hline Age & -0.01 & 1.06 & 0.47 \\
\hline Sex & 0.25 & 1.13 & 0.004 \\
\hline Kinship & 0.19 & 1.97 & 0.007 \\
\hline $\begin{array}{l}\text { Reproductive } \\
\text { status }\end{array}$ & 0.26 & 1.40 & 0.007 \\
\hline Visual gestures & 0.75 & 0.15 & 0.0005 \\
\hline $\begin{array}{l}\text { Auditory long- } \\
\text { range gestures }\end{array}$ & -0.44 & 0.25 & 0.0005 \\
\hline $\begin{array}{l}\text { Auditory short- } \\
\text { range gestures }\end{array}$ & 0.24 & 0.19 & 0.01 \\
\hline Tactile gestures & -0.02 & 0.22 & 0.50 \\
\hline
\end{tabular}

Table S5.8 Duration of visual attention away from dyad partner $\left(r^{2}=0.20\right)$ 


\begin{tabular}{|c|c|c|c|}
\hline & $\begin{array}{l}\text { Standardized } \\
\text { coefficient }\end{array}$ & Standard error & $p$ \\
\hline Age & 0.296 & 1.683 & 0.004 \\
\hline Sex & -0.083 & 1.347 & 0.178 \\
\hline Kinship & 0.064 & 2.799 & 0.129 \\
\hline $\begin{array}{l}\text { Reproductive } \\
\text { status }\end{array}$ & 0.001 & 1.338 & 0.496 \\
\hline $\begin{array}{l}\text { Auditory long- } \\
\text { range gestures }\end{array}$ & -0.032 & 0.368 & 0.412 \\
\hline $\begin{array}{l}\text { Auditory short- } \\
\text { range gestures }\end{array}$ & 0.290 & 0.285 & 0.011 \\
\hline Tactile gestures & 0.031 & 0.366 & 0.247 \\
\hline Visual gestures & 0.033 & 0.179 & 0.327 \\
\hline
\end{tabular}

Table S5.9 Duration of time in close proximity - within $2 \mathrm{~m}\left(r^{2}=0.40\right)$

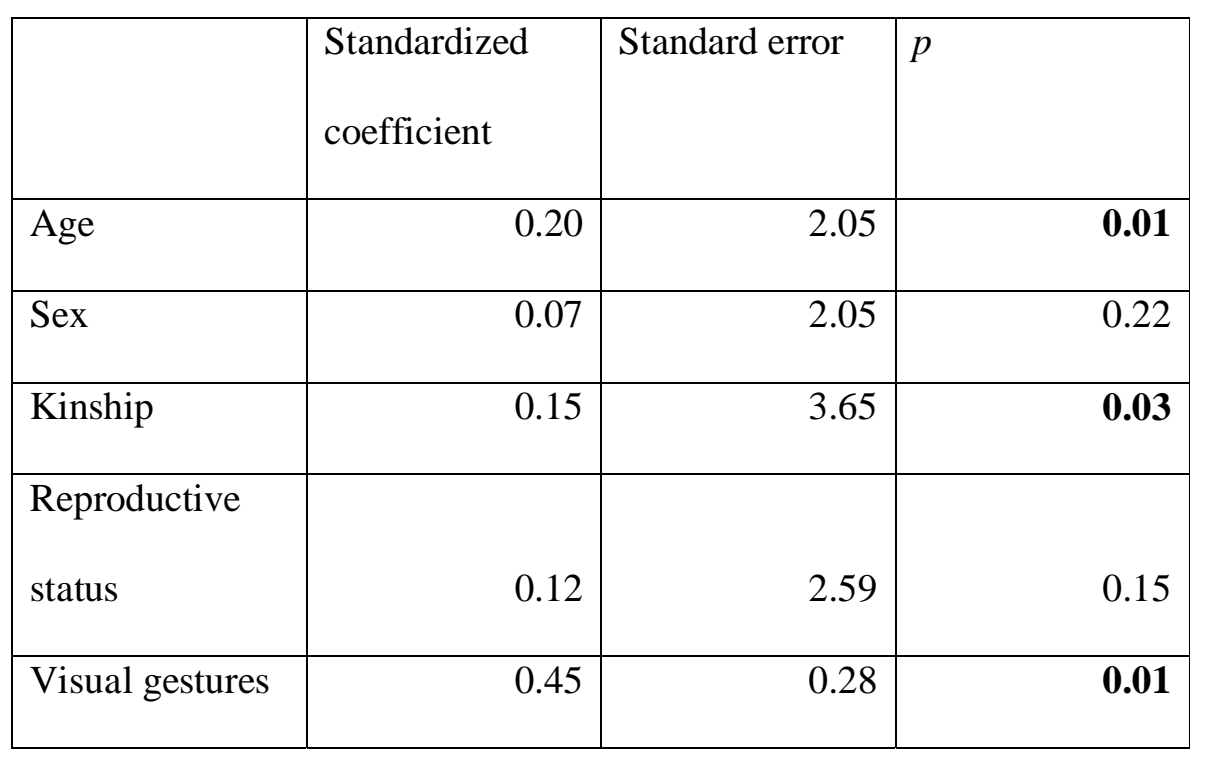




\begin{tabular}{|l|r|r|r|}
\hline & & & \\
\hline Auditory long- & -0.27 & 0.48 & $\mathbf{0 . 0 1}$ \\
\hline Aunge gestures & 0.34 & & \\
range gestures & 0.01 & 0.39 & $\mathbf{0 . 0 1}$ \\
\hline Tactile gestures & & 0.42 & 0.33 \\
& & & \\
\hline
\end{tabular}

Table S5.10 Rate of scratch produced $\left(r^{2}=0.201\right)$

\begin{tabular}{|l|l|l|l|}
\hline & Standardized & Standard error & $p$ \\
\hline Age & -0.064 & & \\
\hline Sex & 0.208 & 0.601 & 0.27286 \\
\hline Kinship & 0.090 & 0.529 & $\mathbf{0 . 0 2 6 9 9}$ \\
\hline Reproductive & -0.019 & 1.128 & \\
\hline status & & 0.430 & 0.14893 \\
\hline Visual gestures & 0.484 & & 0.41979 \\
\hline Auditory long- & -0.163 & 0.071 & \\
\hline range gestures & & 0.126 & $\mathbf{0 . 0 0 8 5}$ \\
\hline Auditory short- & 0.127 & & $\mathbf{0 . 0 4 6 9 8}$ \\
\hline range gestures & & 0.100 & \\
\hline Tactile gestures & -0.072 & & 0.07496 \\
\hline
\end{tabular}


Table S5.11 Rate of scratch received $\left(r^{2}=0.060\right)$

\begin{tabular}{|l|l|l|l|}
\hline & Standardized & Standard error & $p$ \\
\hline Age & 0.03 & 0.65 & \\
\hline Sex & 0.21 & 0.60 & 0.34983 \\
\hline Kinship & 0.08 & 1.23 & $\mathbf{0 . 0 3 4 4 8}$ \\
\hline Reproductive & 0.04 & 0.45 & 0.18041 \\
status & & & 0.29135 \\
\hline Visual gestures & 0.08 & 0.07 & \\
\hline Auditory long- & -0.08 & 0.14 & 0.22539 \\
\hline range gestures & & & $\mathbf{0 . 0 4 9 4 8}$ \\
\hline Auditory short- & -0.10 & & \\
\hline Tange gestures & & & \\
\hline
\end{tabular}

\section{Unimodal and multimodal gestural communication}

Supplementary Table S6. MRQAP regression models predicting durations of social behavior, per hour dyad spent within $10 \mathrm{~m}$. Predictor variables were rates of unimodal and multi-modal gestural communication and demographic variables. Based on 132 chimpanzee dyads. Significant $p$ values are indicated in bold. R squared $\left(r^{2}\right)$ denotes amount of variance in the dependent variable explained by the regression model.

Table S6.1 Duration of joint feeding behaviour $\left(r^{2}=0.14\right)$ 


\begin{tabular}{|l|r|r|r|}
\hline & $\begin{array}{r}\text { Standardized } \\
\text { coefficient }\end{array}$ & Standard error & $p$ \\
\hline Age & -0.01 & 0.69 & 0.47 \\
\hline Sex & 0.31 & 0.68 & $\mathbf{0 . 0 0 2}$ \\
\hline Kinship & 0.28 & 1.29 & $\mathbf{0 . 0 1}$ \\
\hline Reproductive status & 0.20 & 0.73 & $\mathbf{0 . 0 4}$ \\
\hline Unimodal gestures & 0.16 & 0.05 & 0.07 \\
\hline Multimodal (facial & -0.13 & 0.53 & 0.09 \\
expressions) & -0.07 & 0.07 & 0.23 \\
\hline Multimodal & & & \\
(vocalisations) & & & \\
\hline
\end{tabular}

Table S6.2 Duration of joint resting behaviour $\left(r^{2}=0.08\right)$

\begin{tabular}{|c|c|c|c|}
\hline & $\begin{array}{l}\text { Standardized } \\
\text { coefficient }\end{array}$ & Standard error & $p$ \\
\hline Age & 0.28 & 1.45 & 0.004 \\
\hline Sex & -0.16 & 1.36 & 0.10 \\
\hline Kinship & -0.02 & 2.41 & 0.41 \\
\hline $\begin{array}{l}\text { Reproductive } \\
\text { status }\end{array}$ & -0.06 & 1.48 & 0.36 \\
\hline $\begin{array}{l}\text { Unimodal } \\
\text { gestures }\end{array}$ & 0.06 & 0.11 & 0.19 \\
\hline $\begin{array}{l}\text { Multimodal } \\
\text { (facial }\end{array}$ & 0.06 & 1.12 & 0.15 \\
\hline
\end{tabular}




\begin{tabular}{|l|r|r|r|}
\hline expressions) & & & \\
\hline Multimodal & -0.06 & 0.16 & 0.20 \\
(vocalisations) & & & 0.20 \\
\hline
\end{tabular}

Table S6.3 Duration of joint travelling behaviour $\left(r^{2}=0.31\right)$

\begin{tabular}{|c|c|c|c|}
\hline & $\begin{array}{l}\text { Standardized } \\
\text { coefficient }\end{array}$ & Standard error & $p$ \\
\hline Age & 0.24 & 0.34 & 0.01 \\
\hline Sex & -0.01 & 0.31 & 0.41 \\
\hline Kinship & 0.02 & 0.62 & 0.25 \\
\hline $\begin{array}{l}\text { Reproductive } \\
\text { status }\end{array}$ & -0.02 & 0.32 & 0.43 \\
\hline $\begin{array}{l}\text { Unimodal } \\
\text { gestures }\end{array}$ & 0.22 & 0.03 & 0.02 \\
\hline $\begin{array}{l}\text { Multimodal } \\
\text { (facial } \\
\text { expressions) }\end{array}$ & 0.30 & 0.31 & 0.02 \\
\hline $\begin{array}{l}\text { Multimodal } \\
\text { (vocalisations) }\end{array}$ & 0.01 & 0.04 & 0.30 \\
\hline
\end{tabular}

Table S6.4 Duration of giving grooming $\left(r^{2}=0.46\right)$

\begin{tabular}{|c|c|c|c|}
\hline & $\begin{array}{l}\text { Standardized } \\
\text { coefficient }\end{array}$ & Standard error & $p$ \\
\hline Age & 0.13 & 0.38 & 0.03 \\
\hline Sex & 0.05 & 0.38 & 0.24 \\
\hline
\end{tabular}




\begin{tabular}{|l|r|r|r|}
\hline Kinship & 0.11 & 0.72 & 0.05 \\
\hline Reproductive & -0.02 & 0.42 & 0.39 \\
status & 0.75 & 0.04 & $\mathbf{0 . 0 0 0 5}$ \\
\hline Unimodal & & & \\
\hline Multimodal & -0.23 & & $\mathbf{0 . 0 1}$ \\
(facial & & 0.40 & 0.09 \\
expressions) & -0.07 & 0.05 & \\
\hline Multimodal & & & \\
(vocalisations) & & & \\
\hline
\end{tabular}

Table S6.5 Duration of mutual grooming $\left(r^{2}=0.42\right)$

\begin{tabular}{|c|c|c|c|}
\hline & $\begin{array}{l}\text { Standardized } \\
\text { coefficient }\end{array}$ & Standard error & $p$ \\
\hline Age & 0.15 & 0.54 & 0.04 \\
\hline Sex & -0.07 & 0.52 & 0.21 \\
\hline Kinship & 0.02 & 0.94 & 0.29 \\
\hline $\begin{array}{l}\text { Reproductive } \\
\text { status }\end{array}$ & 0.09 & 0.57 & 0.16 \\
\hline $\begin{array}{l}\text { Unimodal } \\
\text { gestures }\end{array}$ & 0.27 & 0.04 & 0.02 \\
\hline $\begin{array}{l}\text { Multimodal } \\
\text { (facial } \\
\text { expressions) }\end{array}$ & 0.44 & 0.47 & 0.002 \\
\hline Multimodal & -0.03 & 0.06 & 0.33 \\
\hline
\end{tabular}




\begin{tabular}{|l|l|l|l|}
\hline (vocalisations) & & & \\
\hline
\end{tabular}

Table S6.6 Duration of receiving grooming $\left(r^{2}=0.08\right)$

\begin{tabular}{|c|c|c|c|}
\hline & $\begin{array}{l}\text { Standardized } \\
\text { coefficient }\end{array}$ & Standard error & $p$ \\
\hline Age & -0.11 & 0.52 & 0.12 \\
\hline Sex & 0.17 & 0.52 & 0.06 \\
\hline Kinship & 0.00 & 0.93 & 0.65 \\
\hline $\begin{array}{l}\text { Reproductive } \\
\text { status }\end{array}$ & 0.04 & 0.61 & 0.36 \\
\hline $\begin{array}{l}\text { Unimodal } \\
\text { gestures }\end{array}$ & 0.25 & 0.04 & 0.04 \\
\hline $\begin{array}{l}\text { Multimodal } \\
\text { (facial } \\
\text { expressions) }\end{array}$ & 0.001 & 0.44 & 0.43 \\
\hline $\begin{array}{l}\text { Multimodal } \\
\text { (vocalisations) }\end{array}$ & -0.09 & 0.05 & 0.06 \\
\hline
\end{tabular}

Table S6.7 Duration of visual attention towards dyad partner $\left(r^{2}=0.50\right)$

\begin{tabular}{|c|c|c|c|}
\hline & $\begin{array}{l}\text { Standardized } \\
\text { coefficient }\end{array}$ & Standard error & $p$ \\
\hline Age & 0.06 & 1.06 & 0.21 \\
\hline Sex & 0.20 & 1.11 & 0.01 \\
\hline Kinship & 0.19 & 1.98 & 0.01 \\
\hline
\end{tabular}




\begin{tabular}{|l|r|r|r|}
\hline Reproductive & 0.22 & 1.46 & $\mathbf{0 . 0 2}$ \\
\hline status & 0.44 & 0.09 & $\mathbf{0 . 0 0 0 5}$ \\
\hline Unimodal & & & \\
\hline Multimodal & 0.31 & 0.93 & $\mathbf{0 . 0 0 3}$ \\
(facial & & & \\
\hline expressions) & -0.09 & 0.12 & $\mathbf{0 . 0 5}$ \\
\hline Multimodal & & & \\
\hline
\end{tabular}

Table S6.8 Duration of visual attention away from dyad partner $\left(r^{2}=0.17\right)$

\begin{tabular}{|c|c|c|c|}
\hline & $\begin{array}{l}\text { Standardized } \\
\text { coefficient }\end{array}$ & Standard error & $p$ \\
\hline Age & 0.344 & 1.712 & 0.001 \\
\hline Sex & -0.065 & 1.286 & 0.254 \\
\hline Kinship & 0.071 & 2.929 & 0.142 \\
\hline $\begin{array}{l}\text { Reproductive } \\
\text { status }\end{array}$ & -0.003 & 1.331 & 0.471 \\
\hline $\begin{array}{l}\text { Multimodal } \\
\text { (facial } \\
\text { expressions) }\end{array}$ & -0.043 & 1.405 & 0.295 \\
\hline $\begin{array}{l}\text { Multimodal } \\
\text { (vocalisations) }\end{array}$ & -0.076 & 0.195 & 0.123 \\
\hline
\end{tabular}




\begin{tabular}{|l|l|l|l|}
\hline Unimodal & 0.270 & 0.132 & $\mathbf{0 . 0 2 4}$ \\
gestures & & & \\
\hline
\end{tabular}

Table S6.9 Duration of time in close proximity - within $2 \mathrm{~m}\left(r^{2}=0.37\right)$

\begin{tabular}{|c|c|c|c|}
\hline & $\begin{array}{l}\text { Standardized } \\
\text { coefficient }\end{array}$ & Standard error & $p$ \\
\hline Age & 0.27 & 2.07 & 0.002 \\
\hline Sex & 0.05 & 2.01 & 0.31 \\
\hline Kinship & 0.15 & 3.55 & 0.03 \\
\hline $\begin{array}{l}\text { Reproductive } \\
\text { status }\end{array}$ & 0.09 & 2.54 & 0.22 \\
\hline $\begin{array}{l}\text { Unimodal } \\
\text { gestures }\end{array}$ & 0.44 & 0.17 & 0.001 \\
\hline $\begin{array}{l}\text { Multimodal } \\
\text { (facial } \\
\text { expressions) }\end{array}$ & 0.14 & 1.69 & 0.05 \\
\hline $\begin{array}{l}\text { Multimodal } \\
\text { (vocalisations) }\end{array}$ & -0.11 & 0.23 & 0.04 \\
\hline
\end{tabular}

Table S6.10 Rate of scratch produced $\left(r^{2}=0.191\right)$

\begin{tabular}{|l|l|l|l|}
\hline & $\begin{array}{l}\text { Standardized } \\
\text { coefficient }\end{array}$ & Standard error & $p$ \\
\hline Age & -0.029 & 0.593 & 0.37781 \\
\hline Sex & 0.171 & 0.536 & 0.05847 \\
\hline
\end{tabular}




\begin{tabular}{|c|c|c|c|}
\hline Kinship & 0.089 & 1.098 & 0.14393 \\
\hline $\begin{array}{l}\text { Reproductive } \\
\text { status }\end{array}$ & -0.018 & 0.448 & 0.43278 \\
\hline $\begin{array}{l}\text { Unimodal } \\
\text { gestures }\end{array}$ & 0.180 & 0.045 & 0.04948 \\
\hline $\begin{array}{l}\text { Multimodal } \\
\text { (facial } \\
\text { expressions) }\end{array}$ & 0.184 & 0.489 & 0.04298 \\
\hline $\begin{array}{l}\text { Multimodal } \\
\text { (vocalisations) }\end{array}$ & 0.138 & 0.065 & 0.06597 \\
\hline
\end{tabular}

Table S6.11 Rate of scratch received $\left(r^{2}=0.056\right)$

\begin{tabular}{|l|l|l|l|}
\hline & Standardized & Standard error & $p$ \\
\hline Age & 0.03 & 0.65 & \\
\hline Sex & 0.20 & 0.56 & 0.38331 \\
\hline Kinship & 0.08 & 1.18 & $\mathbf{0 . 0 3 4 4 8}$ \\
\hline Reproductive & 0.04 & 0.47 & 0.2004 \\
status & & 0.05 & 0.29685 \\
\hline Unimodal & -0.12 & 0.52 & \\
\hline gestures & & & 0.11894 \\
\hline Multimodal & 0.06 & & \\
(facial & & & \\
\hline
\end{tabular}




\begin{tabular}{|l|l|l|l|}
\hline expressions) & & & \\
\hline Multimodal & 0.00 & 0.07 & 0.45377 \\
(vocalisations) & & & \\
\hline
\end{tabular}

\section{Dyadic repertoire size}

Supplementary Table S7. MRQAP regression models predicting durations of social behavior, per hour dyad spent within $10 \mathrm{~m}$. Predictor variables were dyadic repertoire size, per hour dyad spent within 10m and demographic variables. Based on 132 chimpanzee dyads. Significant $p$ values are indicated in bold. R squared $\left(r^{2}\right)$ denotes amount of variance in the dependent variable explained by the regression model.

Table S7.1 Duration of joint feeding behaviour $\left(r^{2}=0.12\right)$

\begin{tabular}{|l|r|r|r|}
\hline & $\begin{array}{l}\text { Standardized } \\
\text { coefficient }\end{array}$ & Standard error & $p$ \\
\hline Age & -0.01 & 0.65 & 0.49 \\
\hline Sex & 0.31 & 0.68 & $\mathbf{0 . 0 0 0 5}$ \\
\hline Kinship & 0.28 & 1.32 & $\mathbf{0 . 0 1}$ \\
\hline Reproductive status & 0.22 & 0.75 & $\mathbf{0 . 0 4}$ \\
\hline Dyadic repertoire & & & 0.45 \\
size & -0.02 & 0.04 & \\
\hline
\end{tabular}

Table S7.2 Duration of joint resting behaviour $\left(r^{2}=0.07\right)$

\begin{tabular}{|c|c|c|c|}
\hline & $\begin{array}{l}\text { Standardized } \\
\text { coefficient }\end{array}$ & Standard error & $p$ \\
\hline Age & 0.29 & 1.43 & 0.003 \\
\hline
\end{tabular}




\begin{tabular}{|l|r|r|r|}
\hline Sex & -0.14 & 1.30 & 0.13 \\
\hline Kinship & -0.02 & 2.58 & 0.43 \\
\hline Reproductive & -0.04 & 1.45 & 0.36 \\
status & 0.001 & 0.10 & 0.38 \\
\hline Dyadic & & & \\
repertoire size & & & \\
\hline
\end{tabular}

Table S7.3 Duration of joint travelling behaviour $\left(r^{2}=0.21\right)$

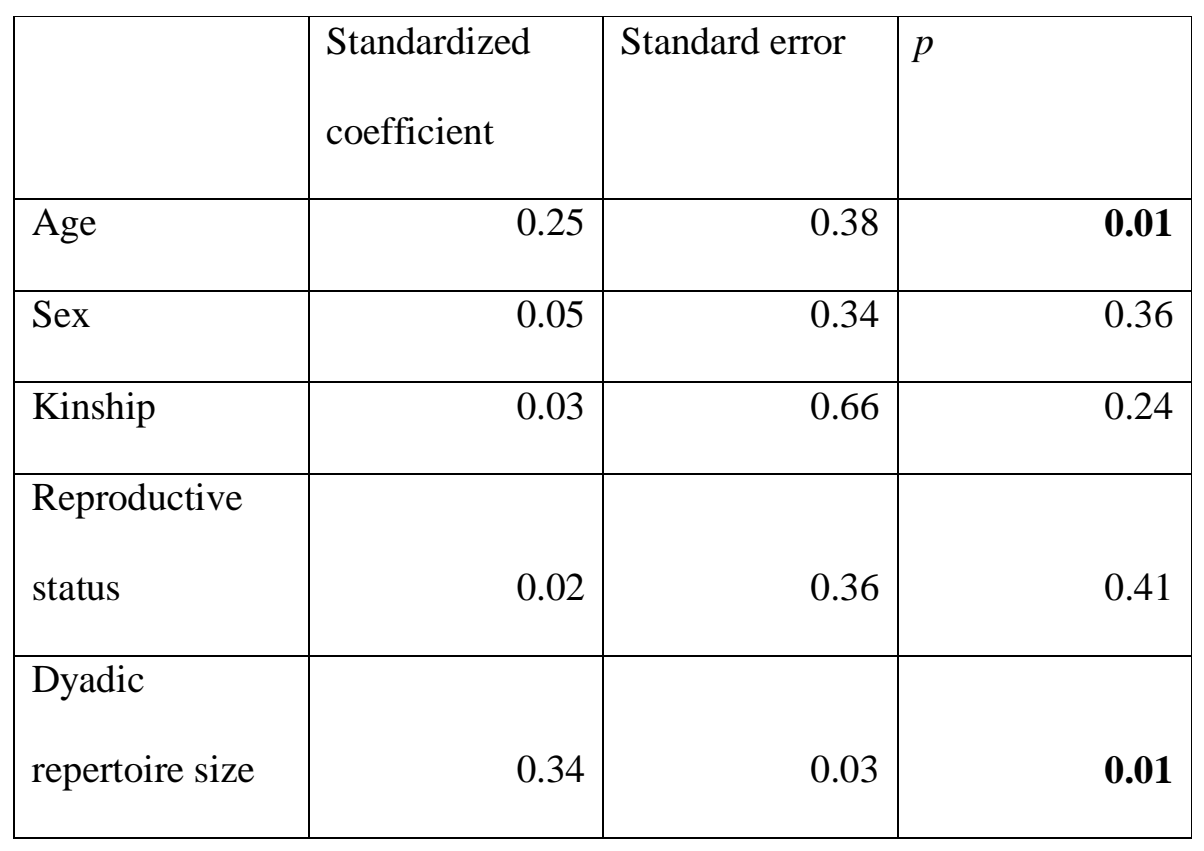

Table S7.4 Duration of giving grooming $\left(r^{2}=0.13\right)$

\begin{tabular}{|c|c|c|c|}
\hline & $\begin{array}{l}\text { Standardized } \\
\text { coefficient }\end{array}$ & Standard error & $p$ \\
\hline Age & 0.18 & 0.53 & 0.02 \\
\hline Sex & 0.10 & 0.52 & 0.17 \\
\hline Kinship & 0.11 & 0.97 & 0.11 \\
\hline
\end{tabular}




\begin{tabular}{|l|r|r|r|}
\hline Reproductive & 0.04 & 0.60 & 0.37 \\
status & 0.26 & & \\
\hline Dyadic & 0.04 & $\mathbf{0 . 0 2}$ \\
\hline
\end{tabular}

Table S7.5 Duration of mutual grooming $\left(r^{2}=0.24\right)$

\begin{tabular}{|c|c|c|c|}
\hline & $\begin{array}{l}\text { Standardized } \\
\text { coefficient }\end{array}$ & Standard error & $p$ \\
\hline Age & 0.16 & 0.60 & 0.05 \\
\hline Sex & 0.01 & 0.59 & 0.51 \\
\hline Kinship & 0.04 & 1.11 & 0.22 \\
\hline $\begin{array}{l}\text { Reproductive } \\
\text { status }\end{array}$ & 0.15 & 0.68 & 0.11 \\
\hline $\begin{array}{l}\text { Dyadic } \\
\text { repertoire size }\end{array}$ & 0.45 & 0.05 & 0.003 \\
\hline
\end{tabular}

Table S7.6 Duration of receiving grooming $\left(r^{2}=0.04\right)$

\begin{tabular}{|c|c|c|c|}
\hline & $\begin{array}{l}\text { Standardized } \\
\text { coefficient }\end{array}$ & Standard error & $p$ \\
\hline Age & -0.10 & 0.49 & 0.13 \\
\hline Sex & 0.20 & 0.50 & 0.03 \\
\hline Kinship & 0.00 & 0.87 & 0.33 \\
\hline $\begin{array}{l}\text { Reproductive } \\
\text { status }\end{array}$ & 0.08 & 0.60 & 0.24 \\
\hline
\end{tabular}




\begin{tabular}{|l|r|r|r|}
\hline Dyadic & 0.14 & & \\
repertoire size & 0.04 & 0.08 \\
\hline
\end{tabular}

Table S7.7 Duration of visual attention towards dyad partner $\left(r^{2}=0.28\right)$

\begin{tabular}{|c|c|c|c|}
\hline & $\begin{array}{l}\text { Standardized } \\
\text { coefficient }\end{array}$ & Standard error & $p$ \\
\hline Age & 0.08 & 1.24 & 0.16 \\
\hline Sex & 0.29 & 1.38 & 0.002 \\
\hline Kinship & 0.21 & 2.50 & 0.02 \\
\hline $\begin{array}{l}\text { Reproductive } \\
\text { status }\end{array}$ & 0.29 & 1.87 & 0.02 \\
\hline $\begin{array}{l}\text { Dyadic } \\
\text { repertoire size }\end{array}$ & 0.42 & 0.11 & 0.002 \\
\hline
\end{tabular}

Table S7.8 Duration of visual attention away from dyad partner $\left(r^{2}=0.12\right)$

\begin{tabular}{|l|l|l|l|}
\hline & Standardized & Standard error & $p$ \\
\hline Age & 0.361 & 1.687 & \\
\hline Sex & -0.065 & 1.276 & $\mathbf{0 . 0 0 1}$ \\
\hline Kinship & 0.074 & 2.826 & 0.255 \\
\hline Reproductive & 0.036 & 1.371 & 0.129 \\
status & & & 0.370 \\
\hline Dyadic & 0.063 & 0.119 & 0.164 \\
repertoire size & & & \\
\hline
\end{tabular}


Table S7.9 Duration of time in close proximity - within $2 \mathrm{~m}\left(r^{2}=0.21\right)$

\begin{tabular}{|c|c|c|c|}
\hline & $\begin{array}{l}\text { Standardized } \\
\text { coefficient }\end{array}$ & Standard error & $p$ \\
\hline Age & 0.29 & 2.38 & 0.001 \\
\hline Sex & 0.11 & 2.27 & 0.15 \\
\hline Kinship & 0.16 & 4.12 & 0.03 \\
\hline $\begin{array}{l}\text { Reproductive } \\
\text { status }\end{array}$ & 0.15 & 3.25 & 0.14 \\
\hline $\begin{array}{l}\text { Dyadic } \\
\text { repertoire size }\end{array}$ & 0.28 & 0.20 & 0.01 \\
\hline
\end{tabular}

Table S7.10 Rate of scratch produced $\left(r^{2}=0.167\right)$

\begin{tabular}{|l|l|l|l|}
\hline & $\begin{array}{l}\text { Standardized } \\
\text { coefficient }\end{array}$ & Standard error & $p$ \\
\hline Age & -0.016 & 0.583 & \\
\hline Sex & 0.193 & 0.529 & 0.43878 \\
\hline Kinship & 0.096 & 1.076 & $\mathbf{0 . 0 3 3 9 8}$ \\
\hline Reproductive & 0.008 & 0.417 & 0.13343 \\
status & & & 0.45527 \\
\hline Dyadic & 0.352 & 0.042 & \\
repertoire size & & & $\mathbf{0 . 0 0 2}$ \\
\hline
\end{tabular}

Table S7.11 Rate of scratch received $\left(r^{2}=0.048\right)$ 


\begin{tabular}{|l|l|l|l|}
\hline & Standardized & Standard error & $p$ \\
\hline Age & 0.02 & 0.62 & \\
\hline Sex & 0.20 & 0.55 & 0.42829 \\
\hline Kinship & 0.08 & 1.21 & $\mathbf{0 . 0 3 6 9 8}$ \\
\hline Reproductive & 0.03 & 0.44 & 0.21039 \\
status & & & 0.38131 \\
\hline Dyadic & -0.04 & 0.04 & \\
repertoire size & & & 0.33483 \\
\hline
\end{tabular}

\section{Single and combined gestures}

Supplementary Table S8. MRQAP regression models predicting durations of social behavior, per hour dyad spent within $10 \mathrm{~m}$. Predictor variables were rates of single and combined gestures, per hour dyad spent within $10 \mathrm{~m}$ and demographic variables. Based on 132 chimpanzee dyads. Significant $p$ values are indicated in bold. R squared $\left(r^{2}\right)$ denotes amount of variance in the dependent variable explained by the regression model.

Table S8.1 Duration of joint feeding behaviour $\left(r^{2}=0.12\right)$

\begin{tabular}{|l|r|r|r|}
\hline & $\begin{array}{l}\text { Standardized } \\
\text { coefficient }\end{array}$ & Standard error & $p$ \\
\hline Age & -0.01 & 0.71 & 0.47 \\
\hline Sex & 0.31 & 0.68 & $\mathbf{0 . 0 0 1}$ \\
\hline Kinship & 0.29 & 1.34 & $\mathbf{0 . 0 1}$ \\
\hline Reproductive status & 0.22 & 0.77 & $\mathbf{0 . 0 4 8}$ \\
\hline Combined gesture & 0.01 & 0.16 & 0.43 \\
\hline
\end{tabular}




\begin{tabular}{|l|r|r|r|}
\hline Single gesture & 0.02 & 0.04 & 0.42 \\
\hline
\end{tabular}

Table S8.2 Duration of joint resting behaviour $\left(r^{2}=0.07\right)$

\begin{tabular}{|c|c|c|c|}
\hline & $\begin{array}{l}\text { Standardized } \\
\text { coefficient }\end{array}$ & Standard error & $p$ \\
\hline Age & 0.28 & 1.38 & 0.002 \\
\hline Sex & -0.15 & 1.32 & 0.11 \\
\hline Kinship & -0.02 & 2.50 & 0.46 \\
\hline $\begin{array}{l}\text { Reproductive } \\
\text { status }\end{array}$ & -0.04 & 1.47 & 0.37 \\
\hline $\begin{array}{l}\text { Combined } \\
\text { gesture }\end{array}$ & -0.03 & 0.34 & 0.37 \\
\hline Single gesture & 0.06 & 0.10 & 0.17 \\
\hline
\end{tabular}

Table S8.3 Duration of joint travelling behaviour $\left(r^{2}=0.31\right)$

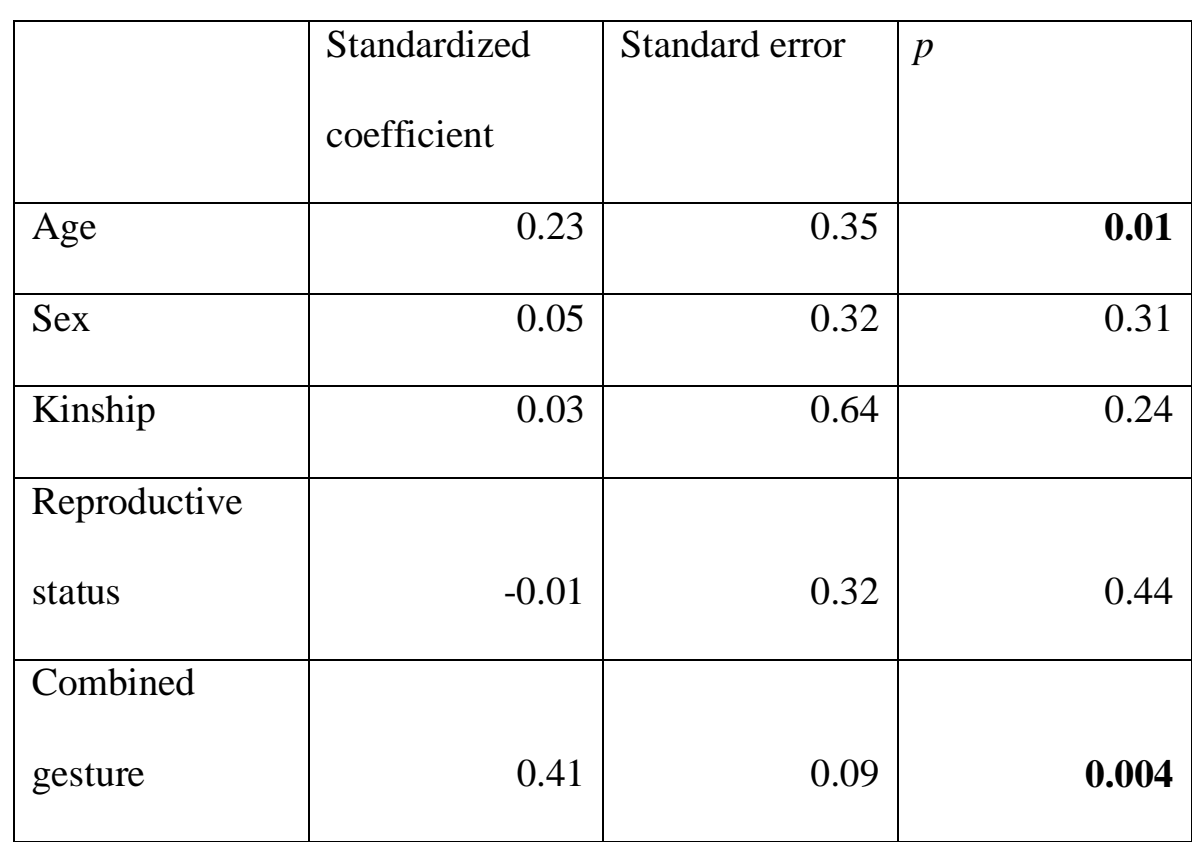




\begin{tabular}{|l|r|r|r|}
\hline Single gesture & 0.09 & 0.02 & 0.12 \\
\hline
\end{tabular}

Table S8.4 Duration of giving grooming $\left(r^{2}=0.35\right)$

\begin{tabular}{|c|c|c|c|}
\hline & $\begin{array}{l}\text { Standardized } \\
\text { coefficient }\end{array}$ & Standard error & $p$ \\
\hline Age & 0.13 & 0.47 & 0.06 \\
\hline Sex & 0.06 & 0.46 & 0.25 \\
\hline Kinship & 0.11 & 0.84 & 0.07 \\
\hline $\begin{array}{l}\text { Reproductive } \\
\text { status }\end{array}$ & 0.06 & 0.51 & 0.30 \\
\hline $\begin{array}{l}\text { Combined } \\
\text { gesture }\end{array}$ & -0.19 & 0.12 & 0.02 \\
\hline Single gesture & 0.64 & 0.04 & 0.001 \\
\hline
\end{tabular}

Table S8.5 Duration of mutual grooming $\left(r^{2}=0.32\right)$

\begin{tabular}{|c|c|c|c|}
\hline & $\begin{array}{l}\text { Standardized } \\
\text { coefficient }\end{array}$ & Standard error & $p$ \\
\hline Age & 0.14 & 0.57 & 0.07 \\
\hline Sex & 0.00 & 0.53 & 0.52 \\
\hline Kinship & 0.04 & 1.04 & 0.23 \\
\hline $\begin{array}{l}\text { Reproductive } \\
\text { status }\end{array}$ & 0.11 & 0.61 & 0.13 \\
\hline $\begin{array}{l}\text { Combined } \\
\text { gesture }\end{array}$ & 0.40 & 0.16 & 0.003 \\
\hline Single gesture & 0.19 & 0.04 & 0.05 \\
\hline
\end{tabular}


Table S8.6 Duration of receiving grooming $\left(r^{2}=0.06\right)$

\begin{tabular}{|c|c|c|c|}
\hline & $\begin{array}{l}\text { Standardized } \\
\text { coefficient }\end{array}$ & Standard error & $p$ \\
\hline Age & -0.11 & 0.49 & 0.11 \\
\hline Sex & 0.19 & 0.49 & 0.02 \\
\hline Kinship & 0.00 & 0.85 & 0.29 \\
\hline $\begin{array}{l}\text { Reproductive } \\
\text { status }\end{array}$ & 0.07 & 0.58 & 0.28 \\
\hline $\begin{array}{l}\text { Combined } \\
\text { gesture }\end{array}$ & 0.13 & 0.15 & 0.11 \\
\hline Single gesture & 0.08 & 0.04 & 0.18 \\
\hline
\end{tabular}

Table S8.7 Duration of visual attention towards dyad partner $\left(r^{2}=0.38\right)$

\begin{tabular}{|c|c|c|c|}
\hline & $\begin{array}{l}\text { Standardized } \\
\text { coefficient }\end{array}$ & Standard error & $p$ \\
\hline Age & 0.05 & 1.19 & 0.28 \\
\hline Sex & 0.28 & 1.26 & 0.002 \\
\hline Kinship & 0.21 & 2.23 & 0.01 \\
\hline $\begin{array}{l}\text { Reproductive } \\
\text { status }\end{array}$ & 0.27 & 1.65 & 0.01 \\
\hline $\begin{array}{l}\text { Combined } \\
\text { gesture }\end{array}$ & 0.30 & 0.30 & 0.002 \\
\hline Single gesture & 0.29 & 0.09 & 0.004 \\
\hline
\end{tabular}

Table S8.8 Duration of visual attention away from dyad partner $\left(r^{2}=0.14\right)$ 


\begin{tabular}{|l|l|l|l|}
\hline & Standardized & Standard error & $p$ \\
\hline Age & 0.341 & & \\
\hline Sex & -0.076 & 1.319 & $\mathbf{0 . 0 0 1}$ \\
\hline Kinship & 0.075 & 2.879 & 0.215 \\
\hline Reproductive & 0.026 & 1.379 & 0.123 \\
status & & & 0.419 \\
\hline Combined & -0.029 & 0.422 & \\
\hline gesture & & & 0.385 \\
\hline Single gesture & 0.183 & 0.112 & $\mathbf{0 . 0 4 5}$ \\
\hline
\end{tabular}

Table S8.9 Duration of time in close proximity - within $2 \mathrm{~m}\left(r^{2}=0.28\right)$

\begin{tabular}{|c|c|c|c|}
\hline & $\begin{array}{l}\text { Standardized } \\
\text { coefficient }\end{array}$ & Standard error & $p$ \\
\hline Age & 0.26 & 2.24 & 0.003 \\
\hline Sex & 0.10 & 2.33 & 0.38 \\
\hline Kinship & 0.17 & 4.09 & 0.05 \\
\hline $\begin{array}{l}\text { Reproductive } \\
\text { status }\end{array}$ & 0.14 & 2.96 & 0.29 \\
\hline $\begin{array}{l}\text { Combined } \\
\text { gesture }\end{array}$ & 0.29 & 0.16 & 0.01 \\
\hline Single gesture & 0.15 & 0.58 & 0.10 \\
\hline
\end{tabular}

Table S8.10 Rate of scratch produced $\left(r^{2}=0.179\right)$ 


\begin{tabular}{|l|l|l|l|}
\hline & Standardized & Standard error & $p$ \\
\hline Age & -0.037 & 0.596 & \\
\hline Sex & 0.194 & 0.530 & 0.33833 \\
\hline Kinship & 0.093 & 1.110 & $\mathbf{0 . 0 3 3 4 8}$ \\
\hline Reproductive & -0.014 & 0.420 & 0.14993 \\
status & & & 0.45027 \\
\hline Combined & 0.155 & 0.154 & \\
gesture & & & 0.06747 \\
\hline Single gesture & 0.259 & 0.039 & $\mathbf{0 . 0 1 6 4 9}$ \\
\hline
\end{tabular}

Table S8.11 Rate of scratch received $\left(r^{2}=0.051\right)$

\begin{tabular}{|l|l|l|l|}
\hline & Standardized & Standard error & $p$ \\
\hline Age & 0.03 & 0.64 & \\
\hline Sex & 0.21 & 0.58 & 0.38431 \\
\hline Kinship & 0.08 & 1.19 & $\mathbf{0 . 0 3 2 4 8}$ \\
\hline Reproductive & 0.03 & 0.44 & 0.18541 \\
status & & & 0.33133 \\
\hline Combined & 0.09 & 0.16 & \\
\hline gesture & & & 0.18041 \\
\hline Single gesture & -0.14 & & 0.05497 \\
\hline
\end{tabular}




\section{Mutual attention accompanying gestures}

Supplementary Table S9. MRQAP regression models predicting durations of social behavior, per hour dyad spent within $10 \mathrm{~m}$. Predictor variables were rates of gestures with and without mutual attention between the recipient and the signaller, per hour dyad spent within $10 \mathrm{~m}$ and demographic variables. Based on 132 chimpanzee dyads. Significant $p$ values are indicated in bold. R squared $\left(r^{2}\right)$ denotes amount of variance in the dependent variable explained by the regression model.

Table S9.1 Duration of joint feeding behaviour $\left(r^{2}=0.12\right)$

\begin{tabular}{|l|r|r|r|}
\hline & $\begin{array}{r}\text { Standardized } \\
\text { coefficient }\end{array}$ & Standard error & $p$ \\
\hline Age & -0.01 & 0.68 & 0.48 \\
\hline Sex & 0.31 & 0.69 & $\mathbf{0 . 0 0 2}$ \\
\hline Kinship & 0.29 & 1.31 & $\mathbf{0 . 0 1}$ \\
\hline Reproductive status & 0.21 & 0.76 & 0.05 \\
\hline Gesture with & 0.05 & & 0.26 \\
mutual attention & -0.04 & 0.06 & 0.38 \\
\hline Gesture without & & & \\
\hline mutual attention & & & \\
\hline
\end{tabular}

Table S9.2 Duration of joint resting behaviour $\left(r^{2}=0.08\right)$

\begin{tabular}{|c|c|c|c|}
\hline & $\begin{array}{l}\text { Standardized } \\
\text { coefficient }\end{array}$ & Standard error & $p$ \\
\hline Age & 0.28 & 1.41 & 0.01 \\
\hline Sex & -0.16 & 1.32 & 0.10 \\
\hline Kinship & -0.02 & 2.41 & 0.44 \\
\hline
\end{tabular}




\begin{tabular}{|l|r|r|r|}
\hline Reproductive & -0.05 & 1.50 & 0.35 \\
\hline status & 0.004 & 0.16 & 0.37 \\
\hline mutual attention & 0.10 & 0.19 & 0.08 \\
\hline Gesture without & & & \\
\hline mutual attention & & & \\
\hline
\end{tabular}

Table S9.3 Duration of joint travelling behaviour $\left(r^{2}=0.28\right)$

\begin{tabular}{|c|c|c|c|}
\hline & $\begin{array}{l}\text { Standardized } \\
\text { coefficient }\end{array}$ & Standard error & $p$ \\
\hline Age & 0.23 & 0.36 & 0.01 \\
\hline Sex & -0.02 & 0.32 & 0.40 \\
\hline Kinship & 0.02 & 0.60 & 0.29 \\
\hline $\begin{array}{l}\text { Reproductive } \\
\text { status }\end{array}$ & -0.03 & 0.31 & 0.39 \\
\hline $\begin{array}{l}\text { Gesture with } \\
\text { mutual attention }\end{array}$ & 0.37 & 0.04 & 0.01 \\
\hline $\begin{array}{l}\text { Gesture without } \\
\text { mutual attention }\end{array}$ & 0.12 & 0.04 & 0.07 \\
\hline
\end{tabular}

Table S9.4 Duration of giving grooming $\left(r^{2}=0.57\right)$

\begin{tabular}{|l|r|r|r|}
\hline & \multicolumn{2}{|l|}{ Standardized } \\
& \multicolumn{1}{|l|}{ coefficient } & Standard error & $p$ \\
\hline Age & 0.16 & 0.39 & $\mathbf{0 . 0 1}$ \\
\hline
\end{tabular}




\begin{tabular}{|l|r|r|r|}
\hline Sex & -0.01 & 0.39 & 0.45 \\
\hline Kinship & 0.10 & 0.72 & 0.07 \\
\hline Reproductive & 0.01 & 0.43 & 0.45 \\
status & -0.11 & 0.04 & $\mathbf{0 . 0 4}$ \\
\hline Gesture with & & & \\
mutual attention & 0.78 & 0.07 & $\mathbf{0 . 0 0 0 5}$ \\
\hline Gesture without & & & \\
\hline mutual attention & & & \\
\hline
\end{tabular}

Table S9.5 Duration of mutual grooming $\left(r^{2}=0.42\right)$

\begin{tabular}{|c|c|c|c|}
\hline & $\begin{array}{l}\text { Standardized } \\
\text { coefficient }\end{array}$ & Standard error & $p$ \\
\hline Age & 0.14 & 0.49 & 0.06 \\
\hline Sex & -0.07 & 0.49 & 0.41 \\
\hline Kinship & 0.03 & 0.94 & 0.68 \\
\hline $\begin{array}{l}\text { Reproductive } \\
\text { status }\end{array}$ & 0.08 & 0.49 & 0.32 \\
\hline $\begin{array}{l}\text { Gesture with } \\
\text { mutual attention }\end{array}$ & 0.63 & 0.07 & 0.001 \\
\hline $\begin{array}{l}\text { Gesture without } \\
\text { mutual attention }\end{array}$ & -0.01 & 0.06 & 0.78 \\
\hline
\end{tabular}

Table S9.6 Duration of receiving grooming $\left(r^{2}=0.07\right)$

\begin{tabular}{|l|l|l|l|}
\hline & Standardized & Standard error & $p$ \\
\hline
\end{tabular}




\begin{tabular}{|l|r|r|r|}
\hline & \multicolumn{2}{|l|}{ coefficient } & \\
\hline Age & -0.11 & 0.49 & 0.10 \\
\hline Sex & 0.17 & 0.48 & 0.051 \\
\hline Kinship & 0.00 & 0.86 & 0.67 \\
\hline Reproductive & 0.06 & 0.55 & 0.30 \\
status & 0.21 & & 0.054 \\
\hline Gesture with & & 0.06 & 0.24 \\
\hline mutual attention & 0.02 & 0.06 & \\
\hline Gesture without & & & \\
mutual attention & & & \\
\hline
\end{tabular}

Table S9.7 Duration of visual attention towards dyad partner $\left(r^{2}=0.49\right)$

\begin{tabular}{|c|c|c|c|}
\hline & $\begin{array}{l}\text { Standardized } \\
\text { coefficient }\end{array}$ & Standard error & $p$ \\
\hline Age & 0.06 & 1.03 & 0.23 \\
\hline Sex & 0.20 & 1.07 & 0.01 \\
\hline Kinship & 0.19 & 1.99 & 0.01 \\
\hline $\begin{array}{l}\text { Reproductive } \\
\text { status }\end{array}$ & 0.22 & 1.33 & 0.02 \\
\hline $\begin{array}{l}\text { Gesture with } \\
\text { mutual attention }\end{array}$ & 0.56 & 0.14 & 0.0005 \\
\hline $\begin{array}{l}\text { Gesture without } \\
\text { mutual attention }\end{array}$ & 0.12 & 0.13 & 0.07 \\
\hline
\end{tabular}

Table S9.8 Duration of visual attention away from dyad partner $\left(r^{2}=0.19\right)$ 


\begin{tabular}{|l|l|l|l|}
\hline & Standardized & Standard error & $p$ \\
\hline Age & 0.348 & 1.662 & $\mathbf{0 . 0 0 1}$ \\
\hline Sex & -0.094 & 1.299 & 0.142 \\
\hline Kinship & 0.068 & 2.725 & 0.130 \\
\hline Reproductive & 0.003 & 1.329 & 0.494 \\
status & & & \\
\hline Gesture with & -0.032 & 0.167 & 0.384 \\
mutual attention & & & $\mathbf{0 . 0 1 5}$ \\
\hline Gesture without & 0.288 & 0.201 & \\
mutual attention & & & \\
\hline
\end{tabular}

Table S9.9 Duration of time in close proximity - within $2 \mathrm{~m}\left(r^{2}=0.36\right)$

\begin{tabular}{|c|c|c|c|}
\hline & $\begin{array}{l}\text { Standardized } \\
\text { coefficient }\end{array}$ & Standard error & $p$ \\
\hline Age & 0.27 & 2.10 & 0.002 \\
\hline Sex & 0.03 & 2.06 & 0.75 \\
\hline Kinship & 0.15 & 3.73 & 0.04 \\
\hline $\begin{array}{l}\text { Reproductive } \\
\text { status }\end{array}$ & 0.10 & 2.57 & 0.36 \\
\hline $\begin{array}{l}\text { Gesture with } \\
\text { mutual attention }\end{array}$ & 0.30 & 0.24 & 0.01 \\
\hline $\begin{array}{l}\text { Gesture without } \\
\text { mutual attention }\end{array}$ & 0.26 & 0.26 & 0.01 \\
\hline
\end{tabular}


Table S9.10 Rate of scratch produced $\left(r^{2}=0.299\right)$

\begin{tabular}{|l|l|l|l|}
\hline & Standardized & Standard error & $p$ \\
\hline Age & -0.031 & 0.540 & \\
\hline Sex & 0.165 & 0.488 & 0.36832 \\
\hline Kinship & 0.086 & 1.004 & 0.05097 \\
\hline Reproductive & -0.033 & 0.402 & 0.15242 \\
status & & & 0.33983 \\
\hline Gesture with & 0.527 & 0.061 & \\
\hline mutual attention & & & $\mathbf{0 . 0 0 1}$ \\
\hline Gesture without & -0.026 & 0.068 & \\
\hline mutual attention & & & 0.43028 \\
\hline
\end{tabular}

Table S9.11 Rate of scratch received $\left(r^{2}=0.058\right)$

\begin{tabular}{|l|l|l|l|}
\hline & $\begin{array}{l}\text { Standardized } \\
\text { coefficient }\end{array}$ & Standard error & $p$ \\
\hline Age & 0.02 & 0.64 & \\
\hline Sex & 0.21 & 0.56 & 0.4018 \\
\hline Kinship & 0.08 & 1.15 & $\mathbf{0 . 0 3 2 9 8}$ \\
\hline Reproductive & 0.04 & 0.44 & 0.17841 \\
status & & & 0.32184 \\
\hline
\end{tabular}




\begin{tabular}{|l|l|l|l|}
\hline Gesture with & 0.05 & 0.06 & 0.24138 \\
mutual attention & & & \\
\hline Gesture without & -0.13 & 0.08 & $\mathbf{0 . 0 4 9 4 8}$ \\
mutual attention & & & \\
\hline
\end{tabular}

\section{Bodily and manual gestures}

Supplementary Table S10. MRQAP regression models predicting durations of social behavior, per hour dyad spent within $10 \mathrm{~m}$. Predictor variables were rates of bodily and manual gestures between the recipient and the signaller, per hour dyad spent within $10 \mathrm{~m}$ and demographic variables. Based on 132 chimpanzee dyads. Significant $p$ values are indicated in bold. R squared $\left(r^{2}\right)$ denotes amount of variance in the dependent variable explained by the regression model.

Table S10.1 Duration of joint feeding behaviour $\left(r^{2}=0.156\right)$

\begin{tabular}{|l|l|l|l|}
\hline & Standardized & Standard error & $p$ \\
\hline Age & -0.043 & 0.674 & \\
\hline Sex & 0.150 & 0.581 & 0.365 \\
\hline Kinship & 0.285 & 1.291 & 0.083 \\
\hline Reproductive status & 0.259 & 0.538 & $\mathbf{0 . 0 1 0}$ \\
\hline Bodily & 0.066 & 0.041 & $\mathbf{0 . 0 0 1}$ \\
\hline Manual & & & 0.237 \\
\hline
\end{tabular}

Table S10.2 Duration of joint resting behaviour $\left(r^{2}=0.072\right)$ 


\begin{tabular}{|l|l|l|l|}
\hline & Standardized & Standard error & $p$ \\
\hline Age & 0.280 & 1.405 & \\
\hline Sex & -0.116 & 1.102 & $\mathbf{0 . 0 0 4}$ \\
\hline Kinship & -0.018 & 2.383 & 0.081 \\
\hline Reproductive & -0.027 & 1.113 & 0.463 \\
status & & & 0.405 \\
\hline Bodily & 0.060 & 0.091 & \\
\hline Manual & -0.014 & 0.192 & 0.169 \\
\hline
\end{tabular}

Table S10.3 Duration of joint travelling behaviour $\left(r^{2}=0.294\right)$

\begin{tabular}{|l|l|l|l|}
\hline & Standardized & Standard error & $p$ \\
\hline Age & 0.177 & 0.345 & \\
\hline Sex & 0.034 & 0.279 & $\mathbf{0 . 0 2 7}$ \\
\hline Kinship & 0.021 & 0.619 & 0.345 \\
\hline Reproductive & -0.066 & 0.252 & 0.286 \\
status & & & 0.191 \\
\hline Bodily & 0.503 & 0.026 & \\
\hline Manual & -0.062 & 0.049 & $\mathbf{0 . 0 0 3}$ \\
\hline
\end{tabular}

Table S10.4 Duration of giving grooming $\left(r^{2}=0.291\right)$ 


\begin{tabular}{|l|l|l|l|}
\hline & Standardized & Standard error & $p$ \\
\hline Age & 0.171 & 0.498 & \\
\hline Sex & 0.045 & 0.410 & $\mathbf{0 . 0 2 5}$ \\
\hline Kinship & 0.124 & & 0.290 \\
\hline Reproductive & 0.092 & 0.919 & 0.078 \\
status & & 0.405 & 0.124 \\
\hline Bodily & 0.220 & & \\
\hline Manual & 0.293 & 0.034 & $\mathbf{0 . 0 2 4}$ \\
\hline
\end{tabular}

Table S10.5 Duration of mutual grooming $\left(r^{2}=0.327\right)$

\begin{tabular}{|l|l|l|l|}
\hline & Standardized & Standard error & $p$ \\
\hline Age & 0.073 & 0.589 & \\
\hline Sex & -0.102 & 0.494 & 0.219 \\
\hline Kinship & 0.031 & 1.081 & 0.132 \\
\hline Reproductive & 0.097 & & 0.270 \\
status & & 0.456 & 0.115 \\
\hline Bodily & 0.585 & 0.043 & \\
\hline Manual & -0.075 & 0.077 & $\mathbf{0 . 0 0 1}$ \\
\hline
\end{tabular}

Table S10.6 Duration of receiving grooming $\left(r^{2}=0.087\right)$ 


\begin{tabular}{|l|l|l|l|}
\hline & Standardized & Standard error & $p$ \\
\hline Age & -0.148 & 0.516 & \\
\hline Sex & 0.123 & 0.426 & $\mathbf{0 . 0 4 6}$ \\
\hline Kinship & 0.004 & 0.886 & 0.099 \\
\hline Reproductive & 0.136 & 0.423 & 0.350 \\
status & & & 0.054 \\
\hline Bodily & 0.255 & 0.037 & \\
\hline Manual & -0.092 & 0.080 & $\mathbf{0 . 0 3 6}$ \\
\hline
\end{tabular}

Table S10.7 Duration of visual attention towards dyad partner $\left(r^{2}=0.421\right)$

\begin{tabular}{|l|l|l|l|}
\hline & Standardized & Standard error & $p$ \\
\hline Age & -0.013 & 1.188 & \\
\hline Sex & 0.070 & 0.977 & 0.452 \\
\hline Kinship & 0.198 & 2.219 & 0.202 \\
\hline Reproductive & 0.261 & & \\
\hline status & & 1.183 & $\mathbf{0 . 0 1 1}$ \\
\hline Bodily & 0.549 & & $\mathbf{0 . 0 0 5}$ \\
\hline Manual & -0.024 & 0.092 & $\mathbf{0 . 0 0 1}$ \\
\hline
\end{tabular}

Table S10.8 Duration of visual attention away from dyad partner $\left(r^{2}=0.144\right)$ 


\begin{tabular}{|l|l|l|l|}
\hline & Standardized & Standard error & $p$ \\
\hline Age & 0.340 & 1.771 & \\
\hline Sex & -0.069 & 1.294 & $\mathbf{0 . 0 0 2}$ \\
\hline Kinship & 0.076 & 2.905 & 0.219 \\
\hline Reproductive & 0.021 & & 0.126 \\
status & & 1.307 & 0.431 \\
\hline Bodily & 0.139 & 0.122 & \\
\hline Manual & 0.028 & 0.226 & 0.083 \\
\hline
\end{tabular}

Table S10.9 Duration of time in close proximity - within $2 \mathrm{~m}\left(r^{2}=0.312\right)$

\begin{tabular}{|l|l|l|l|}
\hline & Standardized & Standard error & $p$ \\
\hline Age & 0.226 & 2.251 & \\
\hline Sex & -0.008 & 1.713 & $\mathbf{0 . 0 0 6}$ \\
\hline Kinship & 0.164 & 4.044 & 0.462 \\
\hline Reproductive & 0.163 & & $\mathbf{0 . 0 3 7}$ \\
status & & 2.074 & 0.052 \\
\hline Bodily & 0.406 & 0.164 & \\
\hline Manual & 0.006 & 0.311 & $\mathbf{0 . 0 0 3}$ \\
\hline
\end{tabular}

Table S10.10 Rate of scratch produced $\left(r^{2}=0.241\right)$ 


\begin{tabular}{|l|l|l|l|}
\hline & Standardized & Standard error & $p$ \\
\hline Age & -0.098 & 0.599 & \\
\hline Sex & 0.189 & 0.522 & 0.14443 \\
\hline Kinship & 0.088 & 1.063 & $\mathbf{0 . 0 3 4 4 8}$ \\
\hline Reproductive & -0.018 & 0.394 & 0.15442 \\
status & & & 0.4038 \\
\hline Bodily & 0.546 & 0.041 & \\
\hline Manual & -0.184 & 0.079 & $\mathbf{0 . 0 0 0 5}$ \\
\hline
\end{tabular}

Table S10.11 Rate of scratch received $\left(r^{2}=0.051\right)$

\begin{tabular}{|l|l|l|l|}
\hline & Standardized & Standard error & $p$ \\
\hline Age & 0.02 & 0.65 & \\
\hline Sex & 0.20 & 0.58 & 0.42129 \\
\hline Kinship & 0.08 & 1.19 & $\mathbf{0 . 0 4 2 4 8}$ \\
\hline Reproductive & 0.04 & 0.45 & 0.1994 \\
status & & & 0.33183 \\
\hline Bodily & -0.02 & 0.04 & \\
\hline Manual & -0.06 & 0.08 & 0.47776 \\
\hline
\end{tabular}

\section{Gesture events}


Supplementary Table S11. MRQAP regression models predicting durations of social behavior, per hour dyad spent within $10 \mathrm{~m}$. Predictor variable was rates of gesture events between the recipient and the signaller, per hour dyad spent within $10 \mathrm{~m}$ and demographic variables. Based on 132 chimpanzee dyads. Significant $p$ values are indicated in bold. $\mathrm{R}$ squared $\left(r^{2}\right)$ denotes amount of variance in the dependent variable explained by the regression model.

Table S11.1 Duration of joint feeding behaviour $\left(r^{2}=0.151\right)$

\begin{tabular}{|l|l|l|l|}
\hline & $\begin{array}{l}\text { Standardized } \\
\text { coefficient }\end{array}$ & Standard error & $p$ \\
\hline Age & -0.026 & 0.656 & 0.417 \\
\hline Sex & 0.149 & 0.567 & 0.076 \\
\hline Kinship & 0.287 & 1.236 & \\
\hline Reproductive status & 0.260 & 0.563 & $\mathbf{0 . 0 0 8}$ \\
\hline Events & -0.008 & 0.027 & $\mathbf{0 . 0 0 3}$ \\
\hline
\end{tabular}

Table S11.2 Duration of joint resting behaviour $\left(r^{2}=0.071\right)$

\begin{tabular}{|l|l|l|l|}
\hline & $\begin{array}{l}\text { Standardized } \\
\text { coefficient }\end{array}$ & Standard error & $p$ \\
\hline Age & 0.287 & 1.397 & $\mathbf{0 . 0 0 5}$ \\
\hline Sex & -0.116 & 1.070 & 0.066 \\
\hline Kinship & -0.018 & 2.342 & 0.451 \\
\hline Reproductive & -0.027 & 1.122 & 0.427 \\
\hline
\end{tabular}




\begin{tabular}{|l|l|l|l|}
\hline status & & & \\
\hline Events & 0.042 & 0.069 & 0.208 \\
\hline
\end{tabular}

Table S11.3 Duration of joint travelling behaviour $\left(r^{2}=0.240\right)$

\begin{tabular}{|l|l|l|l|}
\hline & Standardized & Standard error & $p$ \\
\hline Age & 0.225 & 0.366 & \\
\hline Sex & 0.035 & 0.302 & $\mathbf{0 . 0 1 7}$ \\
\hline Kinship & 0.026 & 0.622 & 0.348 \\
\hline Reproductive & -0.062 & 0.268 & 0.252 \\
status & & & 0.219 \\
\hline Events & 0.396 & 0.018 & $\mathbf{0 . 0 0 3}$ \\
\hline
\end{tabular}

Table S11.4 Duration of giving grooming $\left(r^{2}=0.293\right)$

\begin{tabular}{|l|l|l|l|}
\hline & $\begin{array}{l}\text { Standardized } \\
\text { coefficient }\end{array}$ & Standard error & $p$ \\
\hline Age & 0.141 & 0.484 & \\
\hline Sex & 0.046 & 0.414 & $\mathbf{0 . 0 4 7}$ \\
\hline Kinship & 0.125 & 0.886 & 0.290 \\
\hline Reproductive & 0.086 & 0.389 & 0.064 \\
status & & & 0.128 \\
\hline Events & 0.467 & 0.027 & $\mathbf{0 . 0 0 2}$ \\
\hline
\end{tabular}


Table S11.5 Duration of mutual grooming $\left(r^{2}=0.248\right)$

\begin{tabular}{|l|l|l|l|}
\hline & Standardized & Standard error & $p$ \\
\hline Age & 0.130 & 0.618 & \\
\hline Sex & -0.101 & 0.524 & 0.105 \\
\hline Kinship & 0.035 & 1.110 & 0.150 \\
\hline Reproductive & 0.103 & & 0.241 \\
status & & 0.508 & 0.139 \\
\hline Events & 0.451 & & \\
\hline
\end{tabular}

Table S11.6 Duration of receiving grooming $\left(r^{2}=0.071\right)$

\begin{tabular}{|l|l|l|l|}
\hline & Standardized & Standard error & $p$ \\
\hline Age & -0.117 & 0.483 & \\
\hline Sex & 0.123 & 0.404 & 0.086 \\
\hline Kinship & 0.007 & 0.876 & 0.092 \\
\hline Reproductive & 0.137 & & 0.315 \\
status & & 0.450 & 0.056 \\
\hline Events & 0.164 & & \\
\hline
\end{tabular}

Table S11.7 Duration of visual attention towards dyad partner $\left(r^{2}=0.369\right)$ 


\begin{tabular}{|l|l|l|l|}
\hline & $\begin{array}{l}\text { Standardized } \\
\text { coefficient }\end{array}$ & Standard error & $p$ \\
\hline Age & 0.032 & 1.226 & \\
\hline Sex & 0.071 & 0.973 & 0.344 \\
\hline Kinship & 0.202 & 2.239 & 0.197 \\
\hline Reproductive & 0.265 & & $\mathbf{0 . 0 0 9}$ \\
status & & 1.266 & $\mathbf{0 . 0 0 3}$ \\
\hline Events & 0.474 & 0.067 & $\mathbf{0 . 0 0 1}$ \\
\hline
\end{tabular}

Table S11.8 Duration of visual attention away from dyad partner $\left(r^{2}=0.143\right)$

\begin{tabular}{|l|l|l|l|}
\hline & $\begin{array}{l}\text { Standardized } \\
\text { coefficient }\end{array}$ & Standard error & $p$ \\
\hline Age & 0.346 & 1.708 & \\
\hline Sex & -0.068 & 1.267 & $\mathbf{0 . 0 0 2}$ \\
\hline Kinship & 0.077 & 2.752 & 0.232 \\
\hline Reproductive & 0.021 & 1.362 & 0.095 \\
status & & & 0.430 \\
\hline Events & 0.152 & 0.078 & $\mathbf{0 . 0 4 9}$ \\
\hline
\end{tabular}

Table S11.9 Duration of time in close proximity - within $2 \mathrm{~m}\left(r^{2}=0.288\right)$

\begin{tabular}{|l|l|l|l|}
\hline & $\begin{array}{l}\text { Standardized } \\
\text { coefficient }\end{array}$ & Standard error & $p$ \\
\hline
\end{tabular}




\begin{tabular}{|l|l|l|l|}
\hline Age & 0.256 & 2.271 & $\mathbf{0 . 0 0 5}$ \\
\hline Sex & -0.007 & 1.668 & 0.472 \\
\hline Kinship & 0.168 & 3.990 & $\mathbf{0 . 0 2 7}$ \\
\hline Reproductive & 0.165 & 2.197 & 0.057 \\
\hline status & & 0.122 & \\
\hline Events & 0.373 & $\mathbf{0 . 0 0 3}$ \\
\hline
\end{tabular}

Table S11.10 Rate of scratch produced $\left(r^{2}=0.172\right)$

\begin{tabular}{|l|l|l|l|}
\hline & Standardized & Standard error & $p$ \\
\hline Age & -0.033 & 0.585 & \\
\hline Sex & 0.189 & 0.528 & 0.37281 \\
\hline Kinship & 0.094 & 1.106 & $\mathbf{0 . 0 3 5 9 8}$ \\
\hline Reproductive & -0.016 & 0.432 & 0.15692 \\
status & & & 0.43478 \\
\hline Events & 0.364 & 0.027 & \\
\hline
\end{tabular}

Table S11.11 Rate of scratch received $\left(r^{2}=0.051\right)$

\begin{tabular}{|l|l|l|l|}
\hline & $\begin{array}{l}\text { Standardized } \\
\text { coefficient }\end{array}$ & Standard error & $p$ \\
\hline Age & 0.03 & 0.62 & 0.38731 \\
\hline
\end{tabular}




\begin{tabular}{|l|l|l|l|}
\hline Sex & 0.20 & 0.55 & $\mathbf{0 . 0 3 9 9 8}$ \\
\hline Kinship & 0.08 & 1.14 & 0.1929 \\
\hline Reproductive & 0.04 & 0.46 & 0.33183 \\
status & & & \\
\hline Events & -0.07 & 0.03 & 0.1909 \\
\hline
\end{tabular}

\section{Non-indicative and indicative gestures}

Supplementary Table S12. MRQAP regression models predicting durations of social behavior, per hour dyad spent within $10 \mathrm{~m}$. Predictor variables were rates of non-indicative and indicative gestures between the recipient and the signaller, per hour dyad spent within 10m and demographic variables. Based on 132 chimpanzee dyads. Significant $p$ values are indicated in bold. $\mathrm{R}$ squared $\left(r^{2}\right)$ denotes amount of variance in the dependent variable explained by the regression model.

Table S12.1 Duration of joint feeding behaviour $\left(r^{2}=0.162\right)$

\begin{tabular}{|l|l|l|l|}
\hline & Standardized & Standard error & $p$ \\
\hline Age & -0.044 & 0.652 & \\
\hline Sex & 0.153 & 0.560 & 0.348 \\
\hline Kinship & 0.283 & 1.263 & 0.067 \\
\hline Reproductive status & 0.251 & 0.554 & $\mathbf{0 . 0 0 8}$ \\
\hline Manual indicative & 0.095 & 0.406 & $\mathbf{0 . 0 0 5}$ \\
\hline Manual non- & -0.081 & 0.075 & 0.115 \\
\hline
\end{tabular}




\begin{tabular}{|l|l|l|l|}
\hline indicative & & & \\
\hline
\end{tabular}

Table S12.2 Duration of joint resting behaviour $\left(r^{2}=0.072\right)$

\begin{tabular}{|l|l|l|l|}
\hline & Standardized & Standard error & $p$ \\
\hline Age & 0.287 & 1.414 & \\
\hline Sex & -0.114 & 1.123 & $\mathbf{0 . 0 0 5}$ \\
\hline Kinship & -0.020 & 2.471 & 0.086 \\
\hline Reproductive & -0.028 & 1.123 & 0.445 \\
status & & & 0.427 \\
\hline Manual & 0.046 & 1.028 & 0.161 \\
indicative & & & \\
\hline Manual non- & 0.000 & & \\
indicative & & & 0.622 \\
\hline
\end{tabular}

Table S12.3 Duration of joint travelling behaviour $\left(r^{2}=0.280\right)$

\begin{tabular}{|l|l|l|l|}
\hline & $\begin{array}{l}\text { Standardized } \\
\text { coefficient }\end{array}$ & Standard error & $p$ \\
\hline Age & 0.226 & 0.356 & $\mathbf{0 . 0 1 1}$ \\
\hline Sex & 0.052 & 0.279 & 0.275 \\
\hline Kinship & 0.011 & 0.600 & 0.287 \\
\hline Reproductive & -0.076 & 0.259 & 0.177 \\
status & & & \\
\hline
\end{tabular}




\begin{tabular}{|l|l|l|l|}
\hline Manual & 0.429 & 0.281 & $\mathbf{0 . 0 1 1}$ \\
\hline $\begin{array}{l}\text { Mandicative } \\
\text { indicative }\end{array}$ & & 0.046 & 0.150 \\
\hline
\end{tabular}

Table S12.4 Duration of giving grooming $\left(r^{2}=0.275\right)$

\begin{tabular}{|l|l|l|l|}
\hline & Standardized & Standard error & $p$ \\
\hline Age & coefficient & & \\
\hline Sex & 0.203 & 0.496 & $\mathbf{0 . 0 1 1}$ \\
\hline Kinship & 0.051 & 0.405 & 0.269 \\
\hline Reproductive & 0.096 & 0.938 & 0.080 \\
status & & 0.405 & 0.129 \\
\hline Manual & 0.173 & & \\
indicative & & 0.365 & $\mathbf{0 . 0 3 6}$ \\
\hline Manual non- & 0.354 & & $\mathbf{0 . 0 1 4}$ \\
indicative & & 0.066 & \\
\hline
\end{tabular}

Table S12.5 Duration of mutual grooming $\left(r^{2}=0.362\right)$

\begin{tabular}{|l|l|l|l|}
\hline & $\begin{array}{l}\text { Standardized } \\
\text { coefficient }\end{array}$ & Standard error & $p$ \\
\hline Age & 0.120 & 0.556 & 0.094 \\
\hline Sex & -0.079 & 0.470 & 0.186 \\
\hline
\end{tabular}




\begin{tabular}{|l|l|l|l|}
\hline Kinship & 0.018 & 1.031 & 0.260 \\
\hline Reproductive & 0.079 & 0.452 & 0.179 \\
\hline $\begin{array}{l}\text { Manual } \\
\text { indicative }\end{array}$ & 0.561 & 0.459 & \\
\hline Manual non- & 0.016 & 0.068 & $\mathbf{0 . 0 0 1}$ \\
indicative & & & 0.246 \\
\hline
\end{tabular}

Table S12.6 Duration of receiving grooming $\left(r^{2}=0.071\right)$

\begin{tabular}{|l|l|l|l|}
\hline & Standardized & Standard error & $p$ \\
\hline Age & -0.118 & 0.483 & \\
\hline Sex & 0.132 & 0.414 & 0.089 \\
\hline Kinship & 0.000 & 0.807 & 0.084 \\
\hline Reproductive & 0.135 & 0.436 & 0.685 \\
status & & 0.382 & 0.060 \\
\hline Manual & 0.170 & & $\mathbf{0 . 0 4 6}$ \\
\hline indicative & & 0.070 & \\
\hline Manual non- & -0.019 & & 0.541 \\
indicative & & & \\
\hline
\end{tabular}

Table S12.7 Duration of visual attention towards dyad partner $\left(r^{2}=0.463\right)$

\begin{tabular}{|l|l|l|l|}
\hline & Standardized & Standard error & $p$ \\
\hline
\end{tabular}




\begin{tabular}{|l|l|l|l|}
\hline & coefficient & & \\
\hline Age & 0.029 & 1.052 & 0.342 \\
\hline Sex & 0.092 & 0.851 & 0.098 \\
\hline Kinship & 0.185 & 2.029 & $\mathbf{0 . 0 1 3}$ \\
\hline Reproductive & 0.243 & 1.134 & $\mathbf{0 . 0 0 2}$ \\
status & & & \\
\hline Manual & 0.545 & 0.946 & $\mathbf{0 . 0 0 1}$ \\
indicative & & & \\
\hline Manual non- & 0.057 & & \\
\hline indicative & & 0.139 & \\
\hline
\end{tabular}

Table S12.8 Duration of visual attention away from dyad partner $\left(r^{2}=0.137\right)$

\begin{tabular}{|l|l|l|l|}
\hline & Standardized & Standard error & $p$ \\
\hline Age & 0.359 & 1.719 & \\
\hline Sex & -0.065 & 1.277 & $\mathbf{0 . 0 0 1}$ \\
\hline Kinship & 0.074 & 2.902 & 0.249 \\
\hline Reproductive & 0.023 & 1.329 & 0.134 \\
status & & 1.115 & 0.405 \\
\hline Manual & 0.089 & & 0.112 \\
\hline indicative & & 0.213 & \\
\hline Manual non- & 0.071 & & 0.120 \\
indicative & & & \\
\hline
\end{tabular}


Table S12.9 Duration of time in close proximity - within $2 \mathrm{~m}\left(r^{2}=0.312\right)$

\begin{tabular}{|l|l|l|l|}
\hline & Standardized & Standard error & $p$ \\
\hline Age & 0.263 & 2.228 & \\
\hline Sex & 0.008 & 1.660 & $\mathbf{0 . 0 0 3}$ \\
\hline Kinship & 0.156 & 3.667 & 0.454 \\
\hline Reproductive & 0.154 & 1.997 & $\mathbf{0 . 0 2 6}$ \\
status & & & 0.062 \\
\hline Manual & 0.370 & 1.763 & \\
indicative & & & $\mathbf{0 . 0 0 7}$ \\
\hline Manual non- & 0.081 & 0.295 & 0.144 \\
indicative & & & \\
\hline
\end{tabular}

Table S12.10 Rate of scratch produced $\left(r^{2}=0.193\right)$

\begin{tabular}{|l|l|l|l|}
\hline & Standardized & Standard error & $p$ \\
\hline Age & coefficient & & \\
\hline Sex & -0.039 & 0.574 & 0.34783 \\
\hline Kinship & 0.077 & 0.544 & $\mathbf{0 . 0 3 1 4 8}$ \\
\hline Reproductive & -0.024 & 1.105 & 0.18441 \\
\hline status & & 0.392 & 0.3938 \\
\hline
\end{tabular}




\begin{tabular}{|l|l|l|l|}
\hline Manual & 0.402 & 0.430 & $\mathbf{0 . 0 0 3}$ \\
indicative & & & \\
\hline Manual non- & -0.047 & 0.070 & 0.32234 \\
\hline indicative & & & \\
\hline
\end{tabular}

Table S12.11 Rate of scratch received $\left(r^{2}=0.051\right)$

\begin{tabular}{|l|l|l|l|}
\hline & Standardized & Standard error & $p$ \\
\hline Age & 0.01 & 0.60 & \\
\hline Sex & 0.20 & 0.55 & 0.44328 \\
\hline Kinship & 0.08 & 1.13 & $\mathbf{0 . 0 3 9 9 8}$ \\
\hline Reproductive & 0.03 & 0.44 & 0.17741 \\
status & & & 0.34133 \\
\hline Manual & 0.01 & 0.41 & \\
indicative & & & 0.4023 \\
\hline Manual non- & -0.07 & & \\
indicative & & 0.08 & \\
\hline
\end{tabular}

\section{Gestures made at close and far proximity}

Supplementary Table S13. MRQAP regression models predicting durations of social behavior, per hour dyad spent within $10 \mathrm{~m}$. Predictor variables were rates of gestures made at close and far proximity between the recipient and the signaller, per hour dyad spent within 10m and demographic variables. Based on 132 chimpanzee dyads. Significant $p$ values are indicated in bold. $\mathrm{R}$ squared $\left(r^{2}\right)$ denotes amount of variance in the dependent variable explained by the regression model. 
Table S13.1 Duration of joint feeding behaviour $\left(r^{2}=0.156\right)$

\begin{tabular}{|l|l|l|l|}
\hline & Standardized & Standard error & $p$ \\
\hline Age & -0.026 & 0.641 & \\
\hline Sex & 0.142 & 0.576 & 0.409 \\
\hline Kinship & 0.282 & 1.250 & 0.092 \\
\hline Reproductive status & 0.251 & 0.557 & $\mathbf{0 . 0 0 6}$ \\
\hline Close proximity & 0.055 & 0.053 & $\mathbf{0 . 0 0 3}$ \\
\hline Far proximity & -0.065 & 0.044 & 0.223 \\
\hline
\end{tabular}

Table S13.2 Duration of joint resting behaviour $\left(r^{2}=0.082\right)$

\begin{tabular}{|l|l|l|l|}
\hline & Standardized & Standard error & $p$ \\
\hline Age & 0.284 & 1.421 & \\
\hline Sex & -0.131 & 1.125 & $\mathbf{0 . 0 0 5}$ \\
\hline Kinship & -0.025 & 2.482 & 0.055 \\
\hline Reproductive & -0.040 & 1.124 & 0.423 \\
\hline status & & & 0.365 \\
\hline Close proximity & 0.121 & 0.123 & \\
\hline Far proximity & -0.048 & 0.112 & $\mathbf{0 . 0 4 6}$ \\
\hline
\end{tabular}

Table S13.3 Duration of joint travelling behaviour $\left(r^{2}=0.241\right)$ 


\begin{tabular}{|l|l|l|l|}
\hline & Standardized & Standard error & $p$ \\
\hline Age & 0.225 & 0.360 & \\
\hline Sex & 0.013 & 0.309 & $\mathbf{0 . 0 0 9}$ \\
\hline Kinship & 0.016 & 0.660 & 0.445 \\
\hline Reproductive & -0.059 & 0.275 & 0.314 \\
status & & & 0.248 \\
\hline Close proximity & 0.273 & 0.030 & \\
\hline Far proximity & 0.223 & & $\mathbf{0 . 0 1 5}$ \\
\hline
\end{tabular}

Table S13.4 Duration of giving grooming $\left(r^{2}=0.589\right)$

\begin{tabular}{|l|l|l|l|}
\hline & Standardized & Standard error & $p$ \\
\hline Age & 0.128 & 0.346 & \\
\hline Sex & -0.042 & 0.282 & $\mathbf{0 . 0 1 8}$ \\
\hline Kinship & 0.085 & 0.625 & 0.242 \\
\hline Reproductive & 0.022 & & 0.068 \\
status & & 0.274 & 0.383 \\
\hline Close proximity & 0.765 & & \\
\hline Far proximity & -0.112 & 0.055 & $\mathbf{0 . 0 0 1}$ \\
\hline
\end{tabular}

Table S13.5 Duration of mutual grooming $\left(r^{2}=0.288\right)$ 


\begin{tabular}{|l|l|l|l|}
\hline & Standardized & Standard error & $p$ \\
\hline Age & 0.125 & 0.604 & \\
\hline Sex & -0.136 & 0.518 & 0.101 \\
\hline Kinship & 0.022 & & 0.073 \\
\hline Reproductive & 0.095 & 1.067 & \\
\hline status & & 0.499 & 0.263 \\
\hline Close proximity & 0.387 & & 0.157 \\
\hline Far proximity & 0.223 & 0.052 & \\
\hline
\end{tabular}

Table S13.6 Duration of receiving grooming $\left(r^{2}=0.074\right)$

\begin{tabular}{|l|l|l|l|}
\hline & Standardized & Standard error & $p$ \\
\hline Age & -0.117 & 0.495 & \\
\hline Sex & 0.109 & 0.400 & 0.099 \\
\hline Kinship & 0.001 & 0.897 & 0.128 \\
\hline Reproductive & 0.132 & 0.437 & 0.352 \\
status & & & 0.069 \\
\hline Close proximity & 0.153 & 0.044 & \\
\hline Far proximity & 0.053 & & 0.083 \\
\hline
\end{tabular}

Table S13.7 Duration of visual attention towards dyad partner $\left(r^{2}=0.439\right)$ 


\begin{tabular}{|l|l|l|l|}
\hline & Standardized & Standard error & $p$ \\
\hline Age & 0.026 & 1.152 & \\
\hline Sex & 0.020 & 0.935 & 0.368 \\
\hline Kinship & 0.181 & 2.133 & 0.386 \\
\hline Reproductive & 0.242 & 1.179 & $\mathbf{0 . 0 0 9}$ \\
status & & & $\mathbf{0 . 0 1 0}$ \\
\hline Close proximity & 0.500 & 0.119 & \\
\hline Far proximity & 0.131 & & $\mathbf{0 . 0 0 1}$ \\
\hline
\end{tabular}

Table S13.8 Duration of visual attention away from dyad partner $\left(r^{2}=0.190\right)$

\begin{tabular}{|l|l|l|l|}
\hline & Standardized & Standard error & $p$ \\
\hline Age & 0.341 & 1.683 & \\
\hline Sex & -0.102 & 1.258 & $\mathbf{0 . 0 0 1}$ \\
\hline Kinship & 0.062 & 2.737 & 0.105 \\
\hline Reproductive & -0.005 & 1.292 & 0.144 \\
status & & & 0.481 \\
\hline Close proximity & 0.287 & 0.147 & \\
\hline Far proximity & -0.066 & 0.116 & $\mathbf{0 . 0 2 1}$ \\
\hline
\end{tabular}

Table S13.9 Duration of time in close proximity - within $2 \mathrm{~m}\left(r^{2}=0.376\right)$ 


\begin{tabular}{|l|l|l|l|}
\hline & Standardized & Standard error & $p$ \\
\hline Age & 0.249 & 2.163 & \\
\hline Sex & -0.058 & 1.643 & $\mathbf{0 . 0 0 4}$ \\
\hline Kinship & 0.145 & 3.680 & 0.226 \\
\hline Reproductive & 0.134 & & \\
\hline status & & 2.103 & $\mathbf{0 . 0 3 5}$ \\
\hline Close proximity & 0.480 & & 0.094 \\
\hline Far proximity & 0.029 & 0.213 & \\
\hline
\end{tabular}

Table S13.10 Rate of scratch produced $\left(r^{2}=0.174\right)$

\begin{tabular}{|l|l|l|l|}
\hline & Standardized & Standard error & $p$ \\
\hline Age & -0.032 & 0.582 & \\
\hline Sex & 0.175 & 0.539 & 0.3903 \\
\hline Kinship & 0.089 & 1.120 & 0.05697 \\
\hline Reproductive & -0.007 & 0.445 & 0.15192 \\
status & & & 0.47126 \\
\hline Close proximity & 0.210 & 0.051 & \\
\hline Far proximity & 0.244 & & $\mathbf{0 . 0 2 3 9 9}$ \\
\hline
\end{tabular}

Table S13.11 Rate of scratch received $\left(r^{2}=0.058\right)$ 


\begin{tabular}{|l|l|l|l|}
\hline & Standardized & Standard error & $p$ \\
\hline Age & 0.03 & 0.66 & \\
\hline Sex & 0.22 & 0.58 & 0.3908 \\
\hline Kinship & 0.08 & 1.19 & $\mathbf{0 . 0 3 5 9 8}$ \\
\hline Reproductive & 0.05 & 0.45 & 0.18691 \\
\hline status & & & 0.27236 \\
\hline Close proximity & -0.11 & 0.05 & \\
\hline Far proximity & 0.01 & 0.05 & $\mathbf{0 . 0 4 8 9 8}$ \\
\hline
\end{tabular}

\section{Non-repetitive and repetitive gestures}

Supplementary Table S14. MRQAP regression models predicting durations of social behavior, per hour dyad spent within $10 \mathrm{~m}$. Predictor variables were rates of non-repetitive and repetitive gestures between the recipient and the signaller, per hour dyad spent within $10 \mathrm{~m}$ and demographic variables. Based on 132 chimpanzee dyads. Significant $p$ values are indicated in bold. $\mathrm{R}$ squared $\left(r^{2}\right)$ denotes amount of variance in the dependent variable explained by the regression model.

Table S14.1 Duration of joint feeding behaviour $\left(r^{2}=0.158\right)$

\begin{tabular}{|l|l|l|l|}
\hline & Standardized & Standard error & $p$ \\
\hline Age & -0.029 & 0.658 & \\
\hline Sex & 0.144 & 0.562 & 0.410 \\
\hline Kinship & 0.291 & 1.288 & 0.085 \\
\hline
\end{tabular}




\begin{tabular}{|l|l|l|l|}
\hline Reproductive status & 0.262 & 0.565 & $\mathbf{0 . 0 0 2}$ \\
\hline Non-repetitive & -0.071 & 0.047 & 0.192 \\
\hline Repetitive & 0.090 & 0.051 & 0.158 \\
\hline
\end{tabular}

Table S14.2 Duration of joint resting behaviour $\left(r^{2}=0.072\right)$

\begin{tabular}{|l|l|l|l|}
\hline & Standardized & Standard error & $p$ \\
\hline Age & 0.286 & 1.419 & \\
\hline Sex & -0.116 & 1.101 & $\mathbf{0 . 0 0 5}$ \\
\hline Kinship & -0.019 & 2.464 & 0.064 \\
\hline Reproductive & -0.027 & 1.120 & 0.459 \\
status & & & 0.415 \\
\hline Non-repetitive & 0.028 & 0.102 & \\
\hline Repetitive & 0.021 & 0.126 & 0.245 \\
\hline
\end{tabular}

Table S14.3 Duration of joint travelling behaviour $\left(r^{2}=0.353\right)$

\begin{tabular}{|l|l|l|l|}
\hline & $\begin{array}{l}\text { Standardized } \\
\text { coefficient }\end{array}$ & Standard error & $p$ \\
\hline Age & 0.222 & 0.309 & $\mathbf{0 . 0 0 4}$ \\
\hline Sex & 0.054 & 0.250 & 0.234 \\
\hline Kinship & 0.002 & 0.551 & 0.391 \\
\hline
\end{tabular}




\begin{tabular}{|l|l|l|l|}
\hline Reproductive & -0.080 & 0.215 & 0.138 \\
status & & & \\
\hline Non-repetitive & 0.559 & 0.028 & $\mathbf{0 . 0 0 6}$ \\
\hline Repetitive & -0.092 & 0.028 & 0.065 \\
\hline
\end{tabular}

Table S14.4 Duration of giving grooming $\left(r^{2}=0.409\right)$

\begin{tabular}{|l|l|l|l|}
\hline & Standardized & Standard error & $p$ \\
\hline Age & 0.138 & 0.431 & \\
\hline Sex & 0.028 & 0.355 & $\mathbf{0 . 0 3 0}$ \\
\hline Kinship & 0.129 & 0.770 & 0.343 \\
\hline Reproductive & 0.106 & & \\
\hline status & & 0.358 & $\mathbf{0 . 0 3 5}$ \\
\hline Non-repetitive & -0.061 & 0.035 & \\
\hline Repetitive & 0.606 & 0.047 & 0.115 \\
\hline
\end{tabular}

Table S14.5 Duration of mutual grooming $\left(r^{2}=0.470\right)$

\begin{tabular}{|l|r|r|r|}
\hline & \multicolumn{1}{|l|}{ Standardized } \\
& \multicolumn{1}{l|}{ Soefficient } & Standard error & $p$ \\
\hline Age & 0.126 & 0.509 & 0.059 \\
\hline Sex & -0.074 & 0.420 & 0.186 \\
\hline Kinship & 0.005 & 0.917 & 0.371 \\
\hline
\end{tabular}




\begin{tabular}{|l|r|r|r|}
\hline Reproductive & 0.077 & 0.424 & 0.181 \\
\hline Status & 0.726 & 0.052 & $\mathbf{0 . 0 0 1}$ \\
\hline Ren-repetitive & -0.189 & & $\mathbf{0 . 0 0 4}$ \\
\hline
\end{tabular}

Table S14.6 Duration of receiving grooming $\left(r^{2}=0.080\right)$

\begin{tabular}{|l|l|l|l|}
\hline & Standardized & Standard error & $p$ \\
\hline Age & -0.115 & 0.503 & \\
\hline Sex & 0.131 & 0.424 & 0.094 \\
\hline Kinship & -0.002 & 0.858 & 0.088 \\
\hline Reproductive & 0.133 & & 0.654 \\
status & & 0.436 & 0.065 \\
\hline Non-repetitive & 0.207 & & \\
\hline Repetitive & -0.040 & 0.039 & $\mathbf{0 . 0 3 5}$ \\
\hline
\end{tabular}

Table S14.7 Duration of visual attention towards dyad partner $\left(r^{2}=0.464\right)$

\begin{tabular}{|l|l|l|l|}
\hline & $\begin{array}{l}\text { Standardized } \\
\text { coefficient }\end{array}$ & Standard error & $p$ \\
\hline Age & 0.028 & 1.143 & 0.376 \\
\hline Sex & 0.088 & 0.950 & 0.141 \\
\hline Kinship & 0.179 & 2.173 & $\mathbf{0 . 0 3 2}$ \\
\hline
\end{tabular}




\begin{tabular}{|l|l|l|l|}
\hline Reproductive & 0.249 & 1.127 & $\mathbf{0 . 0 0 2}$ \\
status & & & \\
\hline Non-repetitive & 0.567 & 0.104 & $\mathbf{0 . 0 0 4}$ \\
\hline Repetitive & -0.003 & 0.090 & 0.543 \\
\hline
\end{tabular}

Table S14.8 Duration of visual attention away from dyad partner $\left(r^{2}=0.149\right)$

\begin{tabular}{|l|l|l|l|}
\hline & Standardized & Standard error & $p$ \\
\hline Age & 0.345 & 1.731 & \\
\hline Sex & 0.345 & 1.731 & $\mathbf{0 . 0 0 1}$ \\
\hline Kinship & -0.072 & 1.307 & $\mathbf{0 . 0 0 1}$ \\
\hline Reproductive & 0.077 & & 0.219 \\
status & & 2.732 & 0.107 \\
\hline Non-repetitive & 0.026 & & \\
\hline Repetitive & 0.015 & 0.127 & 0.414 \\
\hline
\end{tabular}

Table S14.9 Duration of time in close proximity - within $2 \mathrm{~m}\left(r^{2}=0.307\right)$

\begin{tabular}{|l|l|l|l|}
\hline & $\begin{array}{l}\text { Standardized } \\
\text { coefficient }\end{array}$ & Standard error & $p$ \\
\hline Age & 0.253 & 2.241 & $\mathbf{0 . 0 0 4}$ \\
\hline Sex & 0.000 & 1.681 & 0.483 \\
\hline Kinship & 0.154 & 3.809 & $\mathbf{0 . 0 3 3}$ \\
\hline
\end{tabular}




\begin{tabular}{|l|l|l|l|}
\hline Reproductive & 0.159 & 2.109 & 0.067 \\
status & & & \\
\hline Non-repetitive & 0.331 & 0.177 & $\mathbf{0 . 0 1 2}$ \\
\hline Repetitive & 0.111 & 0.193 & 0.118 \\
\hline
\end{tabular}

Table S14.10 Rate of scratch produced $\left(r^{2}=0.215\right)$

\begin{tabular}{|l|l|l|l|}
\hline & Standardized & Standard error & $p$ \\
\hline Age & -0.0346 & 0.5810 & 0.37881 \\
\hline Sex & 0.2024 & 0.5279 & $\mathbf{0 . 0 3 2 4 8}$ \\
\hline Kinship & 0.0765 & 1.1127 & \\
\hline Reproductive & -0.0259 & 0.4175 & 0.1919 \\
status & & & 0.38731 \\
\hline Non-repetitive & 0.4196 & 0.0419 & \\
\hline Repetitive & -0.0013 & 0.0470 & 0.55822 \\
\hline
\end{tabular}

Table S14.11 Rate of scratch received $\left(r^{2}=0.060\right)$

\begin{tabular}{|l|l|l|l|}
\hline & $\begin{array}{l}\text { Standardized } \\
\text { coefficient }\end{array}$ & Standard error & $p$ \\
\hline Age & 0.03 & 0.63 & 0.38731 \\
\hline Sex & 0.21 & 0.54 & $\mathbf{0 . 0 2 4 9 9}$ \\
\hline
\end{tabular}




\begin{tabular}{|l|l|l|l|}
\hline Kinship & 0.07 & 1.19 & 0.1959 \\
\hline Reproductive & 0.03 & 0.45 & 0.34633 \\
\hline Non-repetitive & 0.05 & 0.05 & \\
\hline Repetitive & -0.14 & 0.05 & 0.22239 \\
\hline
\end{tabular}

\section{Heterogeneous and homogeneous gestures}

Supplementary Table S15. MRQAP regression models predicting durations of social behavior, per hour dyad spent within $10 \mathrm{~m}$. Predictor variables were rates of heterogeneous and homogeneous gestures between the recipient and the signaller, per hour dyad spent within 10m and demographic variables. Based on 132 chimpanzee dyads. Significant $p$ values are indicated in bold. $\mathrm{R}$ squared $\left(r^{2}\right)$ denotes amount of variance in the dependent variable explained by the regression model.

Table S15.1 Duration of joint feeding behaviour $\left(r^{2}=0\right.$.

\begin{tabular}{|l|l|l|l|}
\hline & Standardized & Standard error & $p$ \\
\hline Age & -0.02 & 0.66 & \\
\hline Sex & 0.15 & 0.58 & 0.41629 \\
\hline Kinship & 0.29 & 1.29 & 0.08346 \\
\hline Reproductive status & 0.26 & 0.55 & $\mathbf{0 . 0 1 1 9 9}$ \\
\hline Heterogeneous & 0.00 & 0.08 & $\mathbf{0 . 0 0 2}$ \\
\hline Homogeneous & -0.01 & 0.04 & 0.43328 \\
\hline
\end{tabular}


Table S15.2 Duration of joint resting behaviour $\left(r^{2}=0.075\right)$

\begin{tabular}{|l|l|l|l|}
\hline & Standardized & Standard error & $p$ \\
\hline Age & 0.27 & 1.44 & \\
\hline Sex & -0.12 & 1.14 & $\mathbf{0 . 0 0 8 5}$ \\
\hline Kinship & -0.02 & 2.40 & 0.08496 \\
\hline Reproductive & -0.03 & 1.12 & 0.44878 \\
\hline status & & & 0.3958 \\
\hline Heterogeneous & -0.02 & 0.20 & \\
\hline Homogeneous & 0.08 & 0.11 & 0.47076 \\
\hline
\end{tabular}

Table S15.3 Duration of joint travelling behaviour $\left(r^{2}=0.251\right)$

\begin{tabular}{|l|l|l|l|}
\hline & Standardized & Standard error & $p$ \\
\hline Age & 0.17 & 0.36 & \\
\hline Sex & 0.01 & 0.29 & $\mathbf{0 . 0 4 0 4 8}$ \\
\hline Kinship & 0.01 & 0.60 & 0.44428 \\
\hline Reproductive & -0.07 & 0.27 & 0.33633 \\
status & & & 0.2019 \\
\hline Heterogeneous & -0.03 & 0.05 & \\
\hline Homogeneous & 0.43 & & 0.38281 \\
\hline
\end{tabular}


Table S15.4 Duration of giving grooming $\left(r^{2}=0.364\right)$

\begin{tabular}{|c|c|c|c|}
\hline & $\begin{array}{l}\text { Standardized } \\
\text { coefficient }\end{array}$ & Standard error & $p$ \\
\hline Age & 0.09 & 0.47 & 0.12944 \\
\hline Sex & 0.02 & 0.39 & 0.3953 \\
\hline Kinship & 0.11 & 0.84 & 0.06697 \\
\hline $\begin{array}{l}\text { Reproductive } \\
\text { status }\end{array}$ & 0.08 & 0.37 & 0.14543 \\
\hline Heterogeneous & 0.11 & 0.07 & 0.06747 \\
\hline Homogeneous & 0.52 & 0.04 & 0.004 \\
\hline
\end{tabular}

Table S15.5 Duration of mutual grooming $\left(r^{2}=0.358\right)$

\begin{tabular}{|l|l|l|l|}
\hline & Standardized & Standard error & $p$ \\
\hline Age & 0.03 & 0.56 & \\
\hline Sex & -0.14 & 0.49 & 0.34533 \\
\hline Kinship & 0.01 & 1.05 & 0.08046 \\
\hline Reproductive & 0.08 & 0.46 & 0.33633 \\
status & & & 0.16392 \\
\hline Heterogeneous & -0.15 & 0.08 & \\
\hline Homogeneous & 0.60 & 0.05 & $\mathbf{0 . 0 1 6 4 9}$ \\
\hline
\end{tabular}


Table S15.6 Duration of receiving grooming $\left(r^{2}=0.072\right)$

\begin{tabular}{|l|l|l|l|}
\hline & Standardized & Standard error & $p$ \\
\hline Age & -0.14 & 0.51 & \\
\hline Sex & 0.11 & 0.42 & 0.05697 \\
\hline Kinship & 0.00 & 0.89 & 0.12544 \\
\hline Reproductive & 0.14 & 0.44 & 0.37831 \\
\hline status & & & 0.05697 \\
\hline Heterogeneous & -0.01 & 0.08 & \\
\hline Homogeneous & 0.17 & 0.04 & $\mathbf{0 . 0 4 8 9 8}$ \\
\hline
\end{tabular}

Table S15.7 Duration of visual attention towards dyad partner $\left(r^{2}=0.455\right)$

\begin{tabular}{|l|l|l|l|}
\hline & Standardized & Standard error & $p$ \\
\hline Age & -0.05 & 1.19 & \\
\hline Sex & 0.04 & 0.98 & 0.23888 \\
\hline Kinship & 0.18 & 2.21 & 0.31434 \\
\hline Reproductive & 0.25 & 1.16 & $\mathbf{0 . 0 1 6 9 9}$ \\
status & & & $\mathbf{0 . 0 0 3 5}$ \\
\hline Heterogeneous & -0.09 & 0.15 & \\
\hline Homogeneous & 0.60 & 0.10 & $\mathbf{0 . 0 4 6 9 8}$ \\
\hline
\end{tabular}


Table S15.8 Duration of visual attention away from dyad partner $\left(r^{2}=0.151\right)$

\begin{tabular}{|l|l|l|l|}
\hline & Standardized & Standard error & $p$ \\
\hline Age & 0.33 & 1.77 & \\
\hline Sex & -0.08 & 1.31 & $\mathbf{0 . 0 0 3 5}$ \\
\hline Kinship & 0.07 & 2.85 & 0.1924 \\
\hline Reproductive & 0.02 & 1.32 & 0.13793 \\
status & & & 0.44478 \\
\hline Heterogeneous & 0.04 & 0.23 & \\
\hline Homogeneous & 0.17 & 0.12 & $\mathbf{0 . 0 4 3 4 8}$ \\
\hline
\end{tabular}

Table S15.9 Duration of time in close proximity - within $2 \mathrm{~m}\left(r^{2}=0.335\right)$

\begin{tabular}{|l|l|l|l|}
\hline & Standardized & Standard error & $p$ \\
\hline Age & 0.20 & 2.25 & \\
\hline Sex & -0.03 & 1.67 & $\mathbf{0 . 0 1 8 9 9}$ \\
\hline Kinship & 0.15 & 3.93 & 0.35082 \\
\hline Reproductive & 0.15 & 2.08 & $\mathbf{0 . 0 3 7 9 8}$ \\
\hline status & & & 0.06597 \\
\hline Heterogeneous & -0.03 & 0.30 & \\
\hline Homogeneous & 0.45 & 0.18 & $\mathbf{0 . 0 0 0 5}$ \\
\hline
\end{tabular}


Table S15.10 Rate of scratch produced $\left(r^{2}=0.186\right)$

\begin{tabular}{|l|l|l|l|}
\hline & Standardized & Standard error & $p$ \\
\hline Age & -0.067 & 0.603 & \\
\hline Sex & 0.169 & 0.540 & 0.25437 \\
\hline Kinship & 0.083 & 1.099 & 0.07046 \\
\hline Reproductive & -0.019 & 0.436 & 0.17341 \\
\hline status & & & 0.42579 \\
\hline Heterogeneous & 0.053 & 0.077 & \\
\hline Homogeneous & 0.378 & 0.042 & $\mathbf{0 . 0 0 2 5}$ \\
\hline
\end{tabular}

Table S15.11 Rate of scratch received $\left(r^{2}=0.054\right)$

\begin{tabular}{|l|l|l|l|}
\hline & Standardized & Standard error & $p$ \\
\hline Age & 0.03 & 0.65 & \\
\hline Sex & 0.21 & 0.57 & 0.36182 \\
\hline Kinship & 0.08 & 1.19 & $\mathbf{0 . 0 3 7 4 8}$ \\
\hline Reproductive & 0.04 & 0.45 & 0.17141 \\
status & & & 0.29985 \\
\hline Heterogeneous & -0.03 & 0.09 & 0.4008 \\
\hline
\end{tabular}




\begin{tabular}{|l|l|l|l|}
\hline Homogeneous & -0.08 & 0.04 & 0.16142 \\
\hline
\end{tabular}

\section{Gestures accompanied by penile erection}

Supplementary Table S16. MRQAP regression models predicting durations of social behavior, per hour dyad spent within $10 \mathrm{~m}$. Predictor variables were rates of gestures between the recipient and the signaller are accompanied by penile erection, per hour dyad spent within $10 \mathrm{~m}$ and demographic variables. Based on 132 chimpanzee dyads. Significant $p$ values are indicated in bold. $\mathrm{R}$ squared $\left(r^{2}\right)$ denotes amount of variance in the dependent variable explained by the regression model.

Table S16.1 Duration of joint feeding behaviour $\left(r^{2}=0.153\right)$

\begin{tabular}{|l|l|l|l|}
\hline & $\begin{array}{l}\text { Standardized } \\
\text { coefficient }\end{array}$ & Standard error & $p$ \\
\hline Age & -0.03 & 0.64 & 0.42429 \\
\hline Sex & 0.16 & 0.58 & 0.07646 \\
\hline Kinship & 0.29 & 1.28 & $\mathbf{0 . 0 0 7}$ \\
\hline Reproductive status & 0.26 & 0.54 & $\mathbf{0 . 0 0 3 5}$ \\
\hline Penile erection & 0.04 & 0.22 & 0.27036 \\
\hline
\end{tabular}

Table S16.2 Duration of joint resting behaviour $\left(r^{2}=0.070\right)$

\begin{tabular}{|l|l|l|l|}
\hline & $\begin{array}{l}\text { Standardized } \\
\text { coefficient }\end{array}$ & Standard error & $p$ \\
\hline Age & 0.29 & 1.40 & $\mathbf{0 . 0 0 2}$ \\
\hline
\end{tabular}




\begin{tabular}{|l|l|l|l|}
\hline Sex & -0.12 & 1.12 & 0.08696 \\
\hline Kinship & -0.02 & 2.49 & 0.45727 \\
\hline Reproductive & -0.02 & 1.10 & 0.4018 \\
\hline status & & & \\
\hline Penile erection & -0.01 & 0.49 & 0.5947 \\
\hline
\end{tabular}

Table S16.3 Duration of joint travelling behaviour $\left(r^{2}=0.095\right)$

\begin{tabular}{|l|l|l|l|}
\hline & Standardized & Standard error & $p$ \\
\hline Age & 0.28 & 0.43 & \\
\hline Sex & 0.06 & 0.34 & $\mathbf{0 . 0 0 5}$ \\
\hline Kinship & 0.01 & 0.74 & 0.27886 \\
\hline Reproductive & -0.02 & 0.33 & 0.29885 \\
status & & & 0.44378 \\
\hline Penile erection & 0.07 & 0.14 & \\
\hline
\end{tabular}

Table S16.4 Duration of giving grooming $\left(r^{2}=0.086\right)$

\begin{tabular}{|l|l|l|l|}
\hline & $\begin{array}{l}\text { Standardized } \\
\text { coefficient }\end{array}$ & Standard error & $p$ \\
\hline Age & 0.21 & 0.56 & \\
\hline Sex & 0.06 & 0.45 & $\mathbf{0 . 0 1 8 9 9}$ \\
\hline Kinship & 0.11 & 0.97 & 0.26137 \\
\hline
\end{tabular}




\begin{tabular}{|l|l|l|l|}
\hline Reproductive & 0.14 & 0.50 & 0.06997 \\
status & & & \\
\hline Penile erection & 0.02 & 0.20 & 0.27086 \\
\hline
\end{tabular}

Table S16.5 Duration of mutual grooming $\left(r^{2}=0.055\right)$

\begin{tabular}{|l|l|l|l|}
\hline & Standardized & Standard error & $p$ \\
\hline Age & 0.19 & 0.74 & \\
\hline Sex & -0.09 & 0.61 & 0.07746 \\
\hline Kinship & 0.01 & 1.22 & 0.1959 \\
\hline Reproductive & 0.16 & 0.65 & 0.28636 \\
status & & & 0.10745 \\
\hline Penile erection & -0.04 & 0.23 & \\
\hline
\end{tabular}

Table S16.6 Duration of receiving grooming $\left(r^{2}=0.047\right)$

\begin{tabular}{|l|l|l|l|}
\hline & Standardized & Standard error & $p$ \\
\hline Age & -0.10 & 0.49 & \\
\hline Sex & 0.12 & 0.41 & 0.15742 \\
\hline Kinship & 0.00 & 0.87 & 0.10745 \\
\hline Reproductive & 0.16 & 0.47 & 0.63968 \\
status & & & $\mathbf{0 . 0 3 1 9 8}$ \\
\hline
\end{tabular}




\begin{tabular}{|l|l|l|l|}
\hline Penile erection & -0.04 & 0.21 & 0.30285 \\
\hline
\end{tabular}

Table S16.7 Duration of visual attention towards dyad partner $\left(r^{2}=0.155\right)$

\begin{tabular}{|l|l|l|l|}
\hline & $\begin{array}{l}\text { Standardized } \\
\text { coefficient }\end{array}$ & Standard error & $p$ \\
\hline Age & 0.10 & 1.40 & 0.16492 \\
\hline Sex & 0.08 & 1.15 & 0.18241 \\
\hline Kinship & 0.18 & 2.68 & 0.06297 \\
\hline Reproductive & 0.33 & 1.66 & $\mathbf{0 . 0 0 4 5}$ \\
status & & & \\
\hline Penile erection & -0.01 & 0.47 & 0.50825 \\
\hline
\end{tabular}

Table S16.8 Duration of visual attention away from dyad partner $\left(r^{2}=0.121\right)$

\begin{tabular}{|l|l|l|l|}
\hline & Standardized & Standard error & $p$ \\
\hline Age & 0.37 & 1.75 & \\
\hline Sex & -0.06 & 1.29 & $\mathbf{0 . 0 0 1 5}$ \\
\hline Kinship & 0.07 & 2.83 & 0.25187 \\
\hline Reproductive & 0.04 & 1.39 & 0.13493 \\
status & & & 0.36932 \\
\hline Penile erection & -0.01 & 0.62 & \\
\hline
\end{tabular}


Table S16.9 Duration of time in close proximity - within $2 \mathrm{~m}\left(r^{2}=0.156\right)$

\begin{tabular}{|l|l|l|l|}
\hline & $\begin{array}{l}\text { Standardized } \\
\text { coefficient }\end{array}$ & Standard error & $p$ \\
\hline Age & 0.31 & 2.55 & \\
\hline Sex & 0.00 & 1.80 & $\mathbf{0 . 0 0 1}$ \\
\hline Kinship & 0.15 & 4.22 & 0.45977 \\
\hline Reproductive & 0.21 & 2.68 & $\mathbf{0 . 0 4 2 4 8}$ \\
status & & & 0.05147 \\
\hline Penile erection & -0.01 & 0.80 & 0.52074 \\
& & & \\
\hline
\end{tabular}

Table S16.10 Rate of scratch produced $\left(r^{2}=0.056\right)$

\begin{tabular}{|l|l|l|l|}
\hline & $\begin{array}{l}\text { Standardized } \\
\text { coefficient }\end{array}$ & Standard error & $p$ \\
\hline Age & 0.021 & 0.607 & 0.41429 \\
\hline Sex & 0.218 & 0.558 & $\mathbf{0 . 0 2 8 4 9}$ \\
\hline Kinship & 0.086 & 1.124 & \\
\hline Reproductive & 0.018 & 0.431 & 0.15942 \\
status & & & 0.42229 \\
\hline Penile erection & 0.102 & 0.222 & \\
\hline
\end{tabular}

Table S16.11 Rate of scratch received $\left(r^{2}=0.046\right)$

\begin{tabular}{|l|l|l|l|}
\hline & Standardized & Standard error & $p$ \\
\hline
\end{tabular}




\begin{tabular}{|c|c|c|c|}
\hline & coefficient & & \\
\hline Age & 0.02 & 0.61 & 0.44728 \\
\hline Sex & 0.20 & 0.55 & 0.04148 \\
\hline Kinship & 0.08 & 1.13 & 0.18291 \\
\hline $\begin{array}{l}\text { Reproductive } \\
\text { status }\end{array}$ & 0.03 & 0.44 & 0.36282 \\
\hline Penile erection & 0.00 & 0.23 & 0.5942 \\
\hline
\end{tabular}

\section{Gestures accompanied by piloerection}

Supplementary Table S17. MRQAP regression models predicting durations of social behavior, per hour dyad spent within $10 \mathrm{~m}$. Predictor variables were rates of gestures between the recipient and the signaller are accompanied by piloerection, per hour dyad spent within $10 \mathrm{~m}$ and demographic variables. Based on 132 chimpanzee dyads. Significant $p$ values are indicated in bold. $\mathrm{R}$ squared $\left(r^{2}\right)$ denotes amount of variance in the dependent variable explained by the regression model.

Table S17.1 Duration of joint feeding behaviour $\left(r^{2}=0.153\right)$

\begin{tabular}{|l|l|l|l|}
\hline & $\begin{array}{l}\text { Standardized } \\
\text { coefficient }\end{array}$ & Standard error & $p$ \\
\hline Age & -0.02 & 0.64 & 0.43828 \\
\hline Sex & 0.15 & 0.57 & 0.08396 \\
\hline Kinship & 0.29 & 1.29 & $\mathbf{0 . 0 0 8 5}$ \\
\hline Reproductive status & 0.26 & 0.57 & $\mathbf{0 . 0 0 2}$ \\
\hline
\end{tabular}




\begin{tabular}{|l|l|l|l|}
\hline Piloerection & -0.04 & 0.04 & 0.35782 \\
\hline
\end{tabular}

Table S17.2 Duration of joint resting behaviour $\left(r^{2}=0.070\right)$

\begin{tabular}{|l|l|l|l|}
\hline & $\begin{array}{l}\text { Standardized } \\
\text { coefficient }\end{array}$ & Standard error & $p$ \\
\hline Age & 0.30 & 1.38 & \\
\hline Sex & -0.12 & 1.11 & $\mathbf{0 . 0 0 4}$ \\
\hline Kinship & -0.02 & 2.39 & 0.08496 \\
\hline Reproductive & -0.02 & 1.13 & 0.43878 \\
status & & & 0.43728 \\
\hline Piloerection & -0.02 & 0.10 & \\
\hline
\end{tabular}

Table S17.3 Duration of joint travelling behaviour $\left(r^{2}=0.231\right)$

\begin{tabular}{|l|l|l|l|}
\hline & $\begin{array}{l}\text { Standardized } \\
\text { coefficient }\end{array}$ & Standard error & $p$ \\
\hline Age & 0.22 & 0.38 & \\
\hline Sex & 0.06 & 0.30 & $\mathbf{0 . 0 1 7 4 9}$ \\
\hline Kinship & 0.02 & 0.65 & 0.24438 \\
\hline Reproductive & -0.03 & 0.28 & 0.28036 \\
status & & & 0.36982 \\
\hline Piloerection & 0.38 & 0.03 & $\mathbf{0 . 0 0 6}$ \\
\hline
\end{tabular}


Table S17.4 Duration of giving grooming $\left(r^{2}=0.094\right)$

\begin{tabular}{|l|l|l|l|}
\hline & Standardized & Standard error & $p$ \\
\hline Age & 0.19 & 0.56 & \\
\hline Sex & 0.06 & 0.44 & $\mathbf{0 . 0 3 0 9 8}$ \\
\hline Kinship & 0.11 & 1.00 & 0.24588 \\
\hline Reproductive & 0.14 & 0.49 & 0.11994 \\
status & & & 0.06747 \\
\hline Piloerection & 0.09 & 0.04 & 0.10845 \\
& & & \\
\hline
\end{tabular}

Table S17.5 Duration of mutual grooming $\left(r^{2}=0.229\right)$

\begin{tabular}{|l|l|l|l|}
\hline & $\begin{array}{l}\text { Standardized } \\
\text { coefficient }\end{array}$ & Standard error & $p$ \\
\hline Age & 0.13 & 0.63 & \\
\hline Sex & -0.07 & 0.52 & 0.10495 \\
\hline Kinship & 0.03 & 1.10 & 0.23188 \\
\hline Reproductive & 0.14 & 0.54 & 0.24588 \\
status & & & 0.08646 \\
\hline Piloerection & 0.42 & 0.04 & \\
\hline
\end{tabular}

Table S17.6 Duration of receiving grooming $\left(r^{2}=0.065\right)$

\begin{tabular}{|l|l|l|l|}
\hline & Standardized & Standard error & $p$ \\
\hline
\end{tabular}




\begin{tabular}{|l|l|l|l|}
\hline & coefficient & & \\
\hline Age & -0.12 & 0.50 & 0.09045 \\
\hline Sex & 0.13 & 0.42 & 0.07896 \\
\hline Kinship & 0.01 & 0.88 & 0.31334 \\
\hline Reproductive & 0.15 & 0.46 & 0.05547 \\
status & & & \\
\hline Piloerection & 0.14 & 0.04 & 0.08896 \\
\hline
\end{tabular}

Table S17.7 Duration of visual attention towards dyad partner $\left(r^{2}=0.278\right)$

\begin{tabular}{|l|l|l|l|}
\hline & $\begin{array}{l}\text { Standardized } \\
\text { coefficient }\end{array}$ & Standard error & $p$ \\
\hline Age & 0.04 & 1.32 & \\
\hline Sex & 0.10 & 1.08 & 0.31284 \\
\hline Kinship & 0.20 & 2.42 & 0.14193 \\
\hline Reproductive & 0.31 & 1.46 & $\mathbf{0 . 0 2 0 9 9}$ \\
status & & & $\mathbf{0 . 0 0 1 5}$ \\
\hline Piloerection & 0.35 & 0.10 & $\mathbf{0 . 0 0 5 5}$ \\
& & & \\
\hline
\end{tabular}

Table S17.8 Duration of visual attention away from dyad partner $\left(r^{2}=0.121\right)$

\begin{tabular}{|l|l|l|l|}
\hline & $\begin{array}{l}\text { Standardized } \\
\text { coefficient }\end{array}$ & Standard error & $p$ \\
\hline Age & 0.36 & 1.76 & $\mathbf{0 . 0 0 1}$ \\
\hline
\end{tabular}




\begin{tabular}{|l|l|l|l|}
\hline Sex & -0.06 & 1.32 & 0.24188 \\
\hline Kinship & 0.07 & 2.87 & 0.13493 \\
\hline Reproductive & 0.04 & 1.42 & 0.35882 \\
status & & & \\
\hline Piloerection & 0.02 & 0.13 & 0.29685 \\
\hline
\end{tabular}

Table S17.9 Duration of time in close proximity - within $2 \mathrm{~m}\left(r^{2}=0.200\right)$

\begin{tabular}{|l|l|l|l|}
\hline & $\begin{array}{l}\text { Standardized } \\
\text { coefficient }\end{array}$ & Standard error & $p$ \\
\hline Age & 0.27 & 2.37 & \\
\hline Sex & 0.01 & 1.77 & $\mathbf{0 . 0 0 2}$ \\
\hline Kinship & 0.16 & 4.15 & 0.41279 \\
\hline Reproductive & 0.20 & 2.52 & $\mathbf{0 . 0 3 8 9 8}$ \\
status & & & $\mathbf{0 . 0 4 2 4 8}$ \\
\hline Piloerection & 0.21 & 0.17 & $\mathbf{0 . 0 2 7 4 9}$ \\
\hline
\end{tabular}

Table S17.10 Rate of scratch produced $\left(r^{2}=0.101\right)$

\begin{tabular}{|l|l|l|l|}
\hline & $\begin{array}{l}\text { Standardized } \\
\text { coefficient }\end{array}$ & Standard error & $p$ \\
\hline Age & -0.020 & 0.618 & \\
\hline Sex & 0.210 & 0.548 & 0.43228 \\
\hline Kinship & 0.088 & 1.150 & $\mathbf{0 . 0 2 6 9 9}$ \\
& & & 0.15892 \\
\hline
\end{tabular}




\begin{tabular}{|l|l|l|l|}
\hline Reproductive & 0.020 & 0.408 & 0.3973 \\
status & & & \\
\hline Piloerection & 0.237 & 0.043 & $\mathbf{0 . 0 2 2 4 9}$ \\
\hline
\end{tabular}

Table S17.11 Rate of scratch received $\left(r^{2}=0.048\right)$

\begin{tabular}{|l|l|l|l|}
\hline & $\begin{array}{l}\text { Standardized } \\
\text { coefficient }\end{array}$ & Standard error & $p$ \\
\hline Age & 0.02 & 0.64 & \\
\hline Sex & 0.20 & 0.56 & 0.4058 \\
\hline Kinship & 0.08 & 1.14 & $\mathbf{0 . 0 4 5 9 8}$ \\
\hline Reproductive & 0.03 & 0.44 & 0.18091 \\
status & & & 0.36332 \\
\hline Piloerection & -0.05 & 0.04 & \\
\hline
\end{tabular}

\section{Single gestures, rapid and persistence sequences}

Supplementary Table S18. MRQAP regression models predicting durations of social behavior, per hour dyad spent within 10m. Predictor variables were rates of single gestures, rapid and persistence sequences between the signaller and the recipient, per hour dyad spent within $10 \mathrm{~m}$ and demographic variables. Based on 132 chimpanzee dyads. Significant $p$ values are indicated in bold. $\mathrm{R}$ squared $\left(r^{2}\right)$ denotes amount of variance in the dependent variable explained by the regression model.

Table S18.1 Duration of joint feeding behaviour $\left(r^{2}=0.157\right)$

\begin{tabular}{|l|l|l|l|}
\hline & Standardized & Standard error & $p$ \\
\hline
\end{tabular}




\begin{tabular}{|l|l|l|l|}
\hline & coefficient & & \\
\hline Age & -0.03 & 0.67 & 0.3978 \\
\hline Sex & 0.14 & 0.58 & 0.09445 \\
\hline Kinship & 0.28 & 1.31 & $\mathbf{0 . 0 0 8}$ \\
\hline Reproductive status & 0.25 & 0.56 & \\
\hline Rapid sequence & -0.06 & 0.19 & $\mathbf{0 . 0 0 4 5}$ \\
\hline Single no sequence & 0.08 & 0.06 & 0.27286 \\
\hline Persistence & -0.03 & 0.53 & 0.16042 \\
\hline
\end{tabular}

Table S18.2 Duration of joint resting behaviour $\left(r^{2}=0.077\right)$

\begin{tabular}{|l|l|l|l|}
\hline & Standardized & Standard error & $p$ \\
\hline Age & 0.29 & 1.39 & \\
\hline Sex & -0.13 & 1.12 & $\mathbf{0 . 0 0 1 5}$ \\
\hline Kinship & -0.02 & 2.41 & 0.05497 \\
\hline Reproductive & -0.04 & 1.13 & 0.44328 \\
status & & & 0.3993 \\
\hline Rapid sequence & -0.03 & 0.47 & \\
\hline Single no & 0.08 & 0.15 & 0.35282 \\
\hline sequence & & & \\
\hline Persistence & 0.03 & & 0.22889 \\
\hline
\end{tabular}


Table S18.3 Duration of joint travelling behaviour $\left(r^{2}=0.259\right)$

\begin{tabular}{|l|l|l|l|}
\hline & Standardized & Standard error & $p$ \\
\hline Age & 0.22 & 0.37 & \\
\hline Sex & 0.02 & 0.31 & $\mathbf{0 . 0 1 4 4 9}$ \\
\hline Kinship & 0.02 & 0.65 & 0.38581 \\
\hline Reproductive & -0.07 & 0.28 & 0.25737 \\
\hline status & & & 0.21689 \\
\hline Rapid sequence & 0.20 & 0.11 & \\
\hline Single no & 0.22 & 0.04 & $\mathbf{0 . 0 2 0 4 9}$ \\
\hline sequence & & & $\mathbf{0 . 0 2 6 9 9}$ \\
\hline Persistence & 0.14 & & \\
\hline
\end{tabular}

Table S18.4 Duration of giving grooming $\left(r^{2}=0.474\right)$

\begin{tabular}{|l|l|l|l|}
\hline & Standardized & Standard error & $p$ \\
\hline Age & 0.11 & 0.41 & \\
\hline Sex & 0.01 & 0.33 & 0.07246 \\
\hline Kinship & 0.10 & 0.73 & 0.41979 \\
\hline Reproductive & 0.02 & 0.34 & 0.05447 \\
status & & & 0.44878 \\
\hline
\end{tabular}




\begin{tabular}{|l|l|l|l|}
\hline Rapid sequence & 0.03 & 0.13 & 0.2024 \\
\hline Single no & 0.66 & 0.06 & $\mathbf{0 . 0 0 1}$ \\
sequence & & & \\
\hline Persistence & -0.05 & 0.38 & 0.14243 \\
\hline
\end{tabular}

Table S18.5 Duration of mutual grooming $\left(r^{2}=0.286\right)$

\begin{tabular}{|l|l|l|l|}
\hline & Standardized & Standard error & $p$ \\
\hline Age & 0.13 & 0.61 & \\
\hline Sex & -0.13 & 0.53 & 0.08346 \\
\hline Kinship & 0.03 & 1.14 & 0.09845 \\
\hline Reproductive & 0.08 & & 0.26437 \\
status & & 0.49 & 0.16942 \\
\hline Rapid sequence & 0.16 & 0.17 & \\
\hline Single no & 0.33 & 0.06 & $\mathbf{0 . 0 4 1 9 8}$ \\
\hline sequence & & & $\mathbf{0 . 0 1 2 4 9}$ \\
\hline Persistence & 0.16 & & \\
\hline
\end{tabular}

Table S18.6 Duration of receiving grooming $\left(r^{2}=0.077\right)$

\begin{tabular}{|l|l|l|l|}
\hline & $\begin{array}{l}\text { Standardized } \\
\text { coefficient }\end{array}$ & Standard error & $p$ \\
\hline Age & -0.11 & 0.51 & 0.12044 \\
\hline
\end{tabular}




\begin{tabular}{|l|l|l|l|}
\hline Sex & 0.11 & 0.43 & 0.13293 \\
\hline Kinship & 0.00 & 0.84 & 0.31384 \\
\hline Reproductive & 0.12 & 0.46 & 0.09595 \\
\hline status & & & \\
\hline Rapid sequence & 0.00 & 0.16 & 0.37331 \\
\hline Single no & 0.16 & 0.05 & 0.05147 \\
\hline sequence & & & \\
\hline Persistence & 0.05 & 0.46 & 0.14343 \\
\hline
\end{tabular}

Table S18.7 Duration of visual attention towards dyad partner $\left(r^{2}=0.433\right)$

\begin{tabular}{|l|l|l|l|}
\hline & Standardized & Standard error & $p$ \\
\hline Age & 0.02 & 1.18 & \\
\hline Sex & 0.04 & 0.97 & 0.38431 \\
\hline Kinship & 0.19 & 2.19 & 0.30135 \\
\hline Reproductive & 0.23 & 1.15 & $\mathbf{0 . 0 1 0 4 9}$ \\
status & & & $\mathbf{0 . 0 2 0 9 9}$ \\
\hline Rapid sequence & 0.09 & 0.36 & \\
\hline Single no & 0.47 & 0.13 & 0.12094 \\
\hline sequence & & & $\mathbf{0 . 0 0 1}$ \\
\hline Persistence & 0.09 & & \\
\hline
\end{tabular}


Table S18.8 Duration of visual attention away from dyad partner $\left(r^{2}=0.168\right)$

\begin{tabular}{|c|c|c|c|}
\hline & $\begin{array}{l}\text { Standardized } \\
\text { coefficient }\end{array}$ & Standard error & $p$ \\
\hline Age & 0.34 & 1.74 & 0.001 \\
\hline Sex & -0.09 & 1.31 & 0.16492 \\
\hline Kinship & 0.07 & 2.71 & 0.12994 \\
\hline $\begin{array}{l}\text { Reproductive } \\
\text { status }\end{array}$ & 0.00 & 1.33 & 0.48226 \\
\hline Rapid sequence & -0.01 & 0.48 & 0.47926 \\
\hline $\begin{array}{l}\text { Single no } \\
\text { sequence }\end{array}$ & 0.23 & 0.17 & 0.02649 \\
\hline Persistence & 0.02 & 1.49 & 0.33083 \\
\hline
\end{tabular}

Table S18.9 Duration of time in close proximity - within $2 \mathrm{~m}\left(r^{2}=0.354\right)$

\begin{tabular}{|l|l|l|l|}
\hline & $\begin{array}{l}\text { Standardized } \\
\text { coefficient }\end{array}$ & Standard error & $p$ \\
\hline Age & 0.25 & 2.19 & \\
\hline Sex & -0.04 & 1.66 & $\mathbf{0 . 0 0 3}$ \\
\hline Kinship & 0.15 & 3.68 & 0.28636 \\
\hline Reproductive & 0.13 & 2.07 & $\mathbf{0 . 0 2 5 4 9}$ \\
status & & & 0.09995 \\
\hline Rapid sequence & 0.04 & 0.65 & 0.27586 \\
& & & \\
\hline
\end{tabular}




\begin{tabular}{|l|l|l|l|}
\hline Single no & 0.42 & 0.25 & $\mathbf{0 . 0 0 0 5}$ \\
sequence & & & \\
\hline Persistence & 0.06 & 1.86 & 0.1954 \\
\hline
\end{tabular}

Table S18.10 Rate of scratch produced $\left(r^{2}=0.397\right)$

\begin{tabular}{|l|l|l|l|}
\hline & Standardized & Standard error & $p$ \\
\hline Age & 0.04 & 0.51 & \\
\hline Sex & 0.12 & 0.46 & 0.29735 \\
\hline Kinship & 0.09 & 0.92 & 0.10395 \\
\hline Reproductive & -0.02 & 0.34 & 0.10645 \\
status & & & 0.4053 \\
\hline Rapid sequence & -0.02 & 0.15 & \\
\hline Single no & 0.08 & 0.05 & 0.44528 \\
sequence & & & $\mathbf{0 . 0 0 0 5}$ \\
\hline Persistence & 0.57 & & \\
\hline
\end{tabular}

Table S18.11 Rate of scratch received $\left(r^{2}=0.061\right)$

\begin{tabular}{|l|l|l|l|}
\hline & $\begin{array}{l}\text { Standardized } \\
\text { coefficient }\end{array}$ & Standard error & $p$ \\
\hline Age & 0.04 & 0.63 & 0.34783 \\
\hline Sex & 0.21 & 0.55 & $\mathbf{0 . 0 3 2 9 8}$ \\
\hline
\end{tabular}




\begin{tabular}{|l|l|l|l|}
\hline Kinship & 0.08 & 1.21 & 0.18141 \\
\hline Status & 0.05 & 0.45 & 0.24938 \\
\hline Rapid sequence & 0.01 & 0.19 & \\
\hline Single no & -0.14 & 0.06 & 0.42379 \\
sequence & & & $\mathbf{0 . 0 4 4 4 8}$ \\
\hline Persistence & 0.06 & 0.51 & \\
\hline
\end{tabular}

\section{$\underline{\text { Association between the duration of social behaviour and gestural communication }}$}

\section{categorized according to function}

\section{Gesture functions}

Supplementary Table S19. MRQAP regression models predicting durations of social behavior, per hour dyad spent within $10 \mathrm{~m}$. Predictors were demographic variables and functions of gestures. Dyads were classified as same age or different age (within 5 years), same sex or different sex, related by maternal kinship and as the same or different reproductive status (reproductively active, not reproductively active). Based on 132 dyadic relationships of the chimpanzees. Significant $p$ values are indicated in bold. R squared $\left(r^{2}\right)$ denotes amount of variance in the dependent variable explained by the regression model.

Table S19.1 Duration of joint feeding behaviour $\left(r^{2}=0.310\right)$

\begin{tabular}{|l|l|l|l|}
\hline & Standardized & Standard error & $p$ \\
& coefficient & & \\
\hline Age & -0.04 & 0.65 & 0.34233 \\
\hline
\end{tabular}




\begin{tabular}{|c|c|c|c|}
\hline Sex & 0.11 & 0.55 & 0.11494 \\
\hline Kinship & 0.27 & 1.20 & 0.0055 \\
\hline Reproductive status & 0.22 & 0.56 & 0.006 \\
\hline Copulation & 0.05 & 0.31 & 0.16292 \\
\hline Food sharing & 0.10 & 8.36 & 0.08096 \\
\hline Threat to dominate & -0.50 & 1.64 & 0.04548 \\
\hline Give groom & 0.17 & 0.13 & 0.03998 \\
\hline Mutually groom & 0.66 & 2.39 & 0.09795 \\
\hline Receive groom & 0.47 & 0.55 & 0.01249 \\
\hline Reassurance & -0.59 & 1.87 & 0.11194 \\
\hline Other threat & -0.02 & 0.71 & 0.41279 \\
\hline Synchronized high-intensity panthoot & -0.08 & 0.29 & 0.10545 \\
\hline Solo high-intensity panthoot & 0.02 & 0.53 & 0.30985 \\
\hline Synchronized low-intensity panthoot & 0.14 & 0.69 & 0.04398 \\
\hline Play & -0.19 & 0.13 & 0.0045 \\
\hline Greeting & -0.11 & 0.30 & 0.05347 \\
\hline Travel & 0.05 & 0.81 & 0.13493 \\
\hline
\end{tabular}

Table S19.2 Duration of joint resting behaviour $\left(r^{2}=0.099\right)$ 


\begin{tabular}{|c|c|c|c|}
\hline & $\begin{array}{l}\text { Standardized } \\
\text { coefficient }\end{array}$ & Standard error & $p$ \\
\hline Age & 0.27 & 1.63 & 0.01499 \\
\hline Sex & -0.12 & 1.25 & 0.08746 \\
\hline Kinship & -0.02 & 2.70 & 0.43428 \\
\hline Reproductive status & -0.05 & 1.28 & 0.35432 \\
\hline Copulation & 0.01 & 0.84 & 0.33883 \\
\hline Food sharing & 0.01 & 23.98 & 0.32234 \\
\hline Threat to dominate & -0.20 & 3.57 & 0.17641 \\
\hline Give groom & 0.11 & 0.31 & 0.06097 \\
\hline Mutually groom & 0.10 & 6.48 & 0.35732 \\
\hline Receive groom & 0.08 & 1.44 & 0.16492 \\
\hline Reassurance & 0.03 & 4.55 & 0.49125 \\
\hline Other threat & -0.03 & 1.75 & 0.32534 \\
\hline $\begin{array}{l}\text { Synchronized high-intensity } \\
\text { panthoot }\end{array}$ & -0.07 & 0.66 & 0.09645 \\
\hline Solo high-intensity panthoot & -0.01 & 1.34 & 0.49825 \\
\hline Synchronized low-intensity panthoot & 0.05 & 2.00 & 0.09045 \\
\hline Play & -0.04 & 0.27 & 0.18841 \\
\hline Greeting & 0.04 & 0.75 & 0.17291 \\
\hline
\end{tabular}




\begin{tabular}{|l|l|l|l|}
\hline Travel & 0.03 & 1.73 & 0.13493 \\
\hline
\end{tabular}

Table S19.3 Duration of joint travelling behaviour $\left(r^{2}=0.420\right)$

\begin{tabular}{|l|l|l|l|}
\hline & $\begin{array}{l}\text { Standardized } \\
\text { coefficient }\end{array}$ & Standard error & $p$ \\
\hline Age & 0.20 & 0.35 & $\mathbf{0 . 0 1 3 9 9}$ \\
\hline Sex & 0.08 & 0.29 & 0.18191 \\
\hline Kinship & 0.02 & 0.58 & 0.24038 \\
\hline Reproductive status & -0.06 & 0.26 & 0.21139 \\
\hline Copulation & 0.05 & 0.18 & 0.08496 \\
\hline Food sharing & -0.01 & 5.05 & 0.44828 \\
\hline Threat to dominate & 0.03 & 1.10 & 0.34733 \\
\hline Give groom & 0.05 & 0.07 & 0.16042 \\
\hline Mutually groom & 0.03 & 1.42 & 0.44578 \\
\hline Receive groom & 0.08 & 0.32 & 0.17391 \\
\hline Reassurance & 0.37 & 1.02 & 0.12394 \\
\hline Other threat & -0.05 & 0.39 & 0.11044 \\
\hline Synchronized high-intensity panthoot & -0.06 & 0.14 & \\
\hline Solo high-intensity panthoot & 0.26 & 0.05547 \\
\hline & & & \\
\hline & & & \\
\hline
\end{tabular}




\begin{tabular}{|l|l|l|l|}
\hline Play & -0.03 & 0.07 & 0.2099 \\
\hline Greeting & 0.01 & 0.17 & 0.34783 \\
\hline Travel & & & \\
\hline
\end{tabular}

Table S19.4 Duration of giving grooming $\left(r^{2}=0.740\right)$

\begin{tabular}{|c|c|c|c|}
\hline & $\begin{array}{l}\text { Standardized } \\
\text { coefficient }\end{array}$ & Standard error & $p$ \\
\hline Age & 0.06 & 0.30 & 0.11244 \\
\hline Sex & -0.01 & 0.24 & 0.3988 \\
\hline Kinship & 0.09 & 0.48 & 0.02199 \\
\hline Reproductive status & 0.00 & 0.23 & 0.53273 \\
\hline Copulation & -0.01 & 0.21 & 0.43878 \\
\hline Food sharing & -0.01 & 6.39 & 0.28286 \\
\hline Threat to dominate & -0.20 & 1.17 & 0.10745 \\
\hline Give groom & 0.69 & 0.12 & 0.0005 \\
\hline Mutually groom & -0.10 & 1.45 & 0.33183 \\
\hline Receive groom & 0.20 & 0.33 & 0.03648 \\
\hline Reassurance & 0.20 & 1.08 & 0.18991 \\
\hline Other threat & -0.06 & 0.47 & 0.02949 \\
\hline Synchronized high-intensity panthoot & 0.03 & 0.18 & 0.12244 \\
\hline
\end{tabular}




\begin{tabular}{|c|c|c|c|}
\hline Solo high-intensity panthoot & 0.00 & 0.34 & 0.38831 \\
\hline Synchronized low-intensity panthoot & -0.04 & 0.44 & 0.06197 \\
\hline Play & 0.19 & 0.09 & 0.01049 \\
\hline Greeting & 0.11 & 0.19 & 0.02549 \\
\hline Travel & 0.10 & 0.54 & 0.03498 \\
\hline
\end{tabular}

Table S19.5 Duration of mutual grooming $\left(r^{2}=0.586\right)$

\begin{tabular}{|c|c|c|c|}
\hline & $\begin{array}{l}\text { Standardized } \\
\text { coefficient }\end{array}$ & Standard error & $p$ \\
\hline Age & 0.12 & 0.53 & 0.07246 \\
\hline Sex & -0.16 & 0.45 & 0.007 \\
\hline Kinship & -0.01 & 0.90 & 0.58871 \\
\hline Reproductive status & 0.08 & 0.42 & 0.11044 \\
\hline Copulation & 0.01 & 0.25 & 0.27386 \\
\hline Food sharing & -0.02 & 9.54 & 0.28936 \\
\hline Threat to dominate & -0.65 & 1.45 & 0.006 \\
\hline Give groom & 0.03 & 0.11 & 0.21839 \\
\hline Mutually groom & 1.14 & 1.97 & 0.01049 \\
\hline Receive groom & 0.53 & 0.48 & 0.0085 \\
\hline Reassurance & -0.25 & 1.47 & 0.21439 \\
\hline
\end{tabular}




\begin{tabular}{|l|l|l|l|}
\hline Other threat & -0.03 & 0.58 & 0.31184 \\
\hline Synchronized high-intensity panthoot & 0.01 & 0.27 & 0.5922 \\
\hline Solo high-intensity panthoot & 0.01 & 0.40 & 0.35582 \\
\hline Synchronized low-intensity panthoot & 0.05 & 0.58 & 0.08146 \\
\hline Play & -0.10 & 0.10 & $\mathbf{0 . 0 1 2 4 9}$ \\
\hline Greeting & -0.05 & 0.21 & 0.11144 \\
\hline Travel & & & 0.34483 \\
\hline
\end{tabular}

Table S19.6 Duration of receiving grooming $\left(r^{2}=0.338\right)$

\begin{tabular}{|l|l|l|l|}
\hline & Standardized & Standard error & $p$ \\
\hline Age & -0.07 & 0.50 & \\
\hline Sex & 0.03 & 0.41 & 0.24388 \\
\hline Kinship & -0.03 & 0.85 & 0.33033 \\
\hline Reproductive status & 0.10 & 0.41 & 0.30585 \\
\hline Copulation & & & 0.11844 \\
\hline Food sharing & -0.02 & 0.24 & 0.43228 \\
\hline Threat to dominate & -0.01 & 6.74 & 0.4038 \\
\hline Give groom & & 1.29 & 0.32384 \\
\hline
\end{tabular}




\begin{tabular}{|l|l|l|l|}
\hline Mutually groom & -0.52 & 2.01 & 0.07346 \\
\hline Receive groom & 0.90 & 0.53 & $\mathbf{0 . 0 0 1}$ \\
\hline Reassurance & -0.04 & 1.37 & 0.37881 \\
\hline Other threat & 0.02 & 0.53 & 0.1919 \\
\hline Synchronized high-intensity & -0.02 & 0.20 & 0.37381 \\
\hline panthoot & & & 0.48626 \\
\hline Synchronized low-intensity panthoot & -0.01 & 0.41 & 0.56172 \\
\hline Play & -0.01 & 0.60 & $\mathbf{0 . 0 0 2}$ \\
\hline Greeting & -0.20 & 0.10 & $\mathbf{0 . 0 4 1 4 8}$ \\
\hline Travel & & 0.25 & \\
\hline
\end{tabular}

Table S19.7 Duration of visual attention towards dyad partner $\left(r^{2}=0.641\right)$

\begin{tabular}{|l|l|l|l|}
\hline & $\begin{array}{l}\text { Standardized } \\
\text { coefficient }\end{array}$ & Standard error & $p$ \\
\hline Age & 0.00 & 1.07 & 0.47326 \\
\hline Sex & 0.01 & 0.86 & 0.43478 \\
\hline Kinship & 0.16 & 1.96 & $\mathbf{0 . 0 1 3 4 9}$ \\
\hline Reproductive status & & 1.06 & $\mathbf{0 . 0 0 1 5}$ \\
\hline
\end{tabular}




\begin{tabular}{|c|c|c|c|}
\hline Copulation & 0.02 & 0.53 & 0.26837 \\
\hline Food sharing & 0.01 & 16.60 & 0.28686 \\
\hline Threat to dominate & -0.64 & 2.91 & 0.0045 \\
\hline Give groom & 0.25 & 0.26 & 0.01149 \\
\hline Mutually groom & 0.79 & 3.97 & 0.02549 \\
\hline Receive groom & 0.51 & 0.96 & 0.001 \\
\hline Reassurance & -0.02 & 3.10 & 0.47926 \\
\hline Other threat & -0.01 & 1.16 & 0.51474 \\
\hline $\begin{array}{l}\text { Synchronized high-intensity } \\
\text { panthoot }\end{array}$ & -0.07 & 0.48 & 0.07146 \\
\hline Solo high-intensity panthoot & 0.03 & 0.89 & 0.24588 \\
\hline Synchronized low-intensity panthoot & 0.10 & 1.25 & 0.04848 \\
\hline Play & -0.09 & 0.24 & 0.01799 \\
\hline Greeting & -0.02 & 0.60 & 0.41529 \\
\hline Travel & 0.04 & 1.33 & 0.14193 \\
\hline
\end{tabular}

Table S19.8 Duration of visual attention away dyad partner $\left(r^{2}=0.276\right)$

\begin{tabular}{|l|l|l|l|}
\hline & $\begin{array}{l}\text { Standardized } \\
\text { coefficient }\end{array}$ & Standard error & $p$ \\
\hline
\end{tabular}




\begin{tabular}{|c|c|c|c|}
\hline Age & 0.33 & 1.87 & 0.001 \\
\hline Sex & -0.10 & 1.41 & 0.11044 \\
\hline Kinship & 0.06 & 2.76 & 0.12744 \\
\hline Reproductive status & -0.03 & 1.35 & 0.38731 \\
\hline Copulation & 0.01 & 0.84 & 0.32584 \\
\hline Food sharing & 0.09 & 26.60 & 0.05147 \\
\hline Threat to dominate & 0.10 & 4.63 & 0.25037 \\
\hline Give groom & 0.24 & 0.37 & 0.01999 \\
\hline Mutually groom & -0.10 & 6.45 & 0.43478 \\
\hline Receive groom & 0.38 & 1.55 & $\mathbf{0 . 0 2 2 4 9}$ \\
\hline Reassurance & -0.29 & 5.47 & 0.2019 \\
\hline Other threat & -0.05 & 2.13 & 0.21489 \\
\hline $\begin{array}{l}\text { Synchronized high-intensity } \\
\text { panthoot }\end{array}$ & -0.09 & 0.72 & 0.04998 \\
\hline Solo high-intensity panthoot & 0.01 & 1.47 & 0.33333 \\
\hline $\begin{array}{l}\text { Synchronized low-intensity } \\
\text { panthoot }\end{array}$ & 0.13 & 2.06 & 0.03598 \\
\hline Play & -0.04 & 0.33 & 0.2044 \\
\hline Greeting & 0.04 & 0.90 & 0.23938 \\
\hline
\end{tabular}




\begin{tabular}{|l|l|l|l|}
\hline Travel & 0.06 & 2.13 & 0.09545 \\
\hline
\end{tabular}

Table S19.9 Duration of time in close proximity - within $2 \mathrm{~m}\left(r^{2}=0.515\right)$

\begin{tabular}{|l|l|l|l|}
\hline & Standardized coefficient & Standard error & $p$ \\
\hline Age & 0.23 & 2.15 & $\mathbf{0 . 0 0 4}$ \\
\hline Sex & -0.06 & 1.62 & 0.16442 \\
\hline Kinship & 0.13 & 3.59 & $\mathbf{0 . 0 4 4 4 8}$ \\
\hline Reproductive status & 0.11 & 1.77 & 0.07546 \\
\hline Copulation & & & \\
\hline Food sharing & 0.02 & 0.99 & 0.25287 \\
\hline Threat to dominate & 0.07 & 29.25 & 0.10595 \\
\hline Give groom & -0.29 & 5.50 & 0.09545 \\
\hline Mutually groom & 0.30 & 0.47 & $\mathbf{0 . 0 0 7 5}$ \\
\hline Receive groom & & 8.36 & 0.16192 \\
\hline Reassurance & 0.38 & 1.95 & $\mathbf{0 . 0 0 6}$ \\
\hline Other threat & 0.55 & 6.33 & 0.27486 \\
\hline Synchronized high-intensity & -0.10 & 2.35 & 0.27936 \\
\hline Solo high-intensity panthoot & 0.03 & 0.89 & $\mathbf{0 . 0 1 2 9 9}$ \\
\hline & -0.21 & & \\
\hline & & & \\
\hline
\end{tabular}




\begin{tabular}{|l|l|l|l|}
\hline Synchronized low-intensity & 0.14 & 2.59 & $\mathbf{0 . 0 2 3 9 9}$ \\
\hline Panthoot & & & \\
\hline Greeting & -0.08 & 0.40 & $\mathbf{0 . 0 4 6 9 8}$ \\
\hline Travel & 0.01 & 1.08 & 0.4013 \\
\hline
\end{tabular}

Table S19.10 Rate of scratch produced $\left(r^{2}=0.465\right)$

\begin{tabular}{|l|l|l|l|}
\hline & Standardized coefficient & Standard error & $p$ \\
\hline Age & -0.05 & 0.55 & 0.30035 \\
\hline Sex & 0.17 & 0.49 & $\mathbf{0 . 0 3 3 4 8}$ \\
\hline Kinship & 0.10 & 0.99 & 0.09045 \\
\hline Reproductive status & 0.01 & 0.41 & 0.46977 \\
\hline Copulation & & & 0.07396 \\
\hline Food sharing & 0.12 & 0.27 & 0.49425 \\
\hline Threat to dominate & -0.02 & 7.31 & 0.1929 \\
\hline Give groom & 0.19 & 1.42 & 0.16542 \\
\hline Mutually groom & -0.20 & 0.12 & 0.15692 \\
\hline Receive groom & 0.10 & 2.05 & \\
\hline & & & \\
\hline & & & \\
\hline
\end{tabular}




\begin{tabular}{|l|l|l|l|}
\hline Other threat & 0.48 & 0.65 & $\mathbf{0 . 0 0 2}$ \\
\hline Synchronized high-intensity & -0.04 & 0.23 & 0.33933 \\
\hline Santhoot & & 0.45 & 0.29785 \\
\hline Synchronized low-intensity & 0.11 & 0.59 & 0.07496 \\
\hline panthoot & -0.04 & & \\
\hline Greeting & -0.05 & 0.11 & 0.1954 \\
\hline Travel & 0.07 & 0.25 & 0.14793 \\
\hline
\end{tabular}

Table S19.11 Rate of scratch received $\left(r^{2}=0.095\right)$

\begin{tabular}{|l|l|l|l|}
\hline & Standardized & Standard error & $p$ \\
\hline Age & 0.09 & 0.72 & \\
\hline Sex & 0.21 & 0.63 & 0.1974 \\
\hline Kinship & 0.09 & 1.34 & 0.17041 \\
\hline Reproductive status & 0.05 & 0.49 & 0.28336 \\
\hline Copulation & & & 0.27186 \\
\hline Food sharing & 0.03 & 0.34 & 0.12894 \\
\hline Threat to dominate & -0.07 & 11.31 & 0.3978 \\
\hline
\end{tabular}




\begin{tabular}{|l|l|l|l|}
\hline Give groom & -0.15 & 0.15 & $\mathbf{0 . 0 2 0 9 9}$ \\
\hline Mutually groom & 0.20 & 2.67 & 0.34183 \\
\hline Receive groom & 0.10 & 0.60 & 0.24288 \\
\hline Reassurance & -0.35 & 2.01 & 0.26787 \\
\hline Other threat & 0.02 & 0.71 & 0.27536 \\
\hline Synchronized high-intensity panthoot & -0.13 & 0.31 & $\mathbf{0 . 0 1 9 4 9}$ \\
\hline Solo high-intensity panthoot & 0.05 & 0.52 & 0.22139 \\
\hline Synchronized low-intensity panthoot & 0.09 & & 0.10795 \\
\hline Play & & 0.67 & 0.28136 \\
\hline Greeting & -0.05 & 0.14 & \\
\hline Travel & & & \\
\hline
\end{tabular}

Hobaiter K, Byrne R. 2011. Serial gesturing by wild chimpanzees: Its nature and function for communication. Animal Cognition 14:827-838.

Nishida T, Zamma K, Matsusaka T, Inaba A, McGrew WC. 2010. Chimpanzee behavior in the wild: An audio-visual encyclopedia. Tokyo: Springer.

Roberts Al, Roberts SGB, Vick S-J. 2014. The repertoire and intentionality of gestural communication in wild chimpanzees. Animal Cognition 17(2):317 - 336. 
Supplementary Information 2

\section{Social bonding, gestural complexity and displacement behaviour of wild chimpanzee}

Table 1. Multiple Regression Quadratic Assignment Procedure (MRQAP) regression models predicting duration of social behaviour and rates of scratch from rates of gestural communication. Summary table provides standardized coefficients (standard errors) and $p$ values. In all models, the dependent variable was the duration of behaviour in mins, per hour dyad spent within 10 meters or rates of scratch per hour dyad spent within 10 meters. Shaded lines indicate different MRQAP models for demographic variables and for each type of gestural communication. All models include the control variables relating to the age, sex, kinship and reproductive status of the dyad. Green shading indicates statistically significant positive relationships, red shading indicates statistically significant negative relationships. Full results for all models are provided in Supplementary Tables. $* p<0.05, * * p<0.01, * * * p<0.001$

\begin{tabular}{|c|c|c|c|c|c|c|c|c|c|c|c|}
\hline \multirow[b]{2}{*}{ Behaviour } & \multicolumn{3}{|c|}{ Joint activity } & \multicolumn{3}{|l|}{ Groom } & \multicolumn{2}{|l|}{ Attention } & \multirow[t]{2}{*}{ Proximity } & \multicolumn{2}{|l|}{ Scratch } \\
\hline & Feed & Rest & Travel & Give & Mutual & Receive & present & absent & & Produced & Received \\
\hline \multicolumn{12}{|l|}{ Demography } \\
\hline Age & $\begin{array}{l}-0.01 \\
(0.65)\end{array}$ & $\begin{array}{l}0.29 \\
(1.37)^{* *}\end{array}$ & $\begin{array}{l}0.28 \\
(0.42)^{* *}\end{array}$ & $\begin{array}{l}0.21 \\
(0.54)^{*}\end{array}$ & $\begin{array}{l}0.20 \\
(0.70) * * *\end{array}$ & $\begin{array}{l}-0.09 \\
(0.48)\end{array}$ & $\begin{array}{l}0.12 \\
(1.47)\end{array}$ & $\begin{array}{l}0.37 \\
(1.73)^{* *}\end{array}$ & $\begin{array}{l}0.32 \\
(2.50) * * *\end{array}$ & $\begin{array}{l}0.02 \\
(0.61)\end{array}$ & $\begin{array}{l}0.02 \\
(0.61)\end{array}$ \\
\hline Sex & $\begin{array}{l}0.31 \\
(0.69)^{* *}\end{array}$ & $\begin{array}{l}-0.14 \\
(1.31)\end{array}$ & $\begin{array}{l}0.05 \\
(0.39)\end{array}$ & $\begin{array}{l}0.11 \\
(0.53)\end{array}$ & $\begin{array}{l}0.12 \\
(2.49)\end{array}$ & $\begin{array}{l}0.20 \\
(0.51)^{*}\end{array}$ & $\begin{array}{l}0.30 \\
(1.55)^{* *}\end{array}$ & $\begin{array}{l}-0.06 \\
(1.28)\end{array}$ & $\begin{array}{l}0.12 \\
(2.49)\end{array}$ & $\begin{array}{l}0.20 \\
(0.56)^{*}\end{array}$ & $\begin{array}{l}0.20 \\
(0.56)^{*}\end{array}$ \\
\hline Kinship & $\begin{array}{l}0.28 \\
(1.28)^{*}\end{array}$ & $\begin{array}{l}-0.02 \\
(2.25)\end{array}$ & $\begin{array}{l}0.01 \\
(0.72)\end{array}$ & $\begin{array}{l}0.10 \\
(0.96)\end{array}$ & $\begin{array}{l}0.15 \\
(4.39) \\
\end{array}$ & $\begin{array}{l}-0.01 \\
(0.88)\end{array}$ & $\begin{array}{l}0.18 \\
(2.62) \\
\end{array}$ & $\begin{array}{l}0.07 \\
(2.78) \\
\end{array}$ & $\begin{array}{l}0.15 \\
(4.39)\end{array}$ & $\begin{array}{l}0.08 \\
(1.14)\end{array}$ & $\begin{array}{l}0.08 \\
(1.14)\end{array}$ \\
\hline $\begin{array}{l}\text { Reproductive } \\
\text { status }\end{array}$ & $\begin{array}{l}0.22 \\
(0.72)^{*}\end{array}$ & $\begin{array}{l}0.04 \\
(1.46)\end{array}$ & $\begin{array}{l}0.01 \\
(0.43)\end{array}$ & $\begin{array}{l}0.03 \\
(0.42)\end{array}$ & $\begin{array}{l}0.14 \\
(3.55)\end{array}$ & $\begin{array}{l}0.08 \\
(0.63)\end{array}$ & \begin{tabular}{|l}
0.28 \\
$(2.12)^{*}$
\end{tabular} & $\begin{array}{l}0.04 \\
(1.39)\end{array}$ & $\begin{array}{l}0.14 \\
(3.55)\end{array}$ & $\begin{array}{l}0.03 \\
(0.42)\end{array}$ & $\begin{array}{l}0.03 \\
(0.44)\end{array}$ \\
\hline \multicolumn{12}{|l|}{ Modality } \\
\hline Visual & $\begin{array}{l}0.15 \\
(0.07)\end{array}$ & $\begin{array}{l}0.02 \\
(0.15)\end{array}$ & $\begin{array}{l}0.62 \\
(0.04)^{*}\end{array}$ & $\begin{array}{l}-0.26 \\
(0.04) * *\end{array}$ & $\begin{array}{l}0.88 \\
(0.07) * * *\end{array}$ & $\begin{array}{l}0.50 \\
(0.06)^{*}\end{array}$ & $\begin{array}{l}0.75 \\
(0.15) * * *\end{array}$ & $\begin{array}{l}0.033 \\
(0.179)\end{array}$ & $\begin{array}{l}0.45 \\
(0.28)^{*}\end{array}$ & $\begin{array}{l}0.48 \\
(0.07)^{*}\end{array}$ & $\begin{array}{l}0.08 \\
(0.07)\end{array}$ \\
\hline ASR & $\begin{array}{l}0.21 \\
(0.11)^{*}\end{array}$ & $\begin{array}{l}0.13 \\
(0.24)^{*}\end{array}$ & $\begin{array}{l}0.04 \\
(0.05)\end{array}$ & $\begin{array}{l}0.73 \\
(0.09) \\
* * *\end{array}$ & $\begin{array}{l}0.01 \\
(0.08)\end{array}$ & $\begin{array}{l}0.04 \\
(0.08)\end{array}$ & $\begin{array}{l}0.24 \\
(0.19)^{*}\end{array}$ & $\begin{array}{l}0.290 \\
(0.28)^{*}\end{array}$ & $\begin{array}{l}0.34 \\
(0.39)^{*}\end{array}$ & $\begin{array}{l}0.13 \\
(0.10)\end{array}$ & $\begin{array}{l}-0.10 \\
(0.10)^{*}\end{array}$ \\
\hline ALR & $\begin{array}{l}-0.08 \\
(0.13)\end{array}$ & $\begin{array}{l}-0.06 \\
(0.34)\end{array}$ & $\frac{-0.28}{(0.08) * *}$ & $\begin{array}{l}0.19 \\
(0.08)^{*}\end{array}$ & $\frac{-0.51}{(0.12) * * *}$ & $\frac{-0.27}{(0.13)^{*}}$ & $\frac{-0.44}{(0.25) * * *}$ & $\begin{array}{l}-0.03 \\
(0.37)\end{array}$ & $\frac{-0.27}{(0.48) * *}$ & $\frac{-0.16}{(0.13) *}$ & $\begin{array}{l}-0.08 \\
(0.14)\end{array}$ \\
\hline Tactile & -0.22 & 0.004 & -0.02 & 0.41 & -0.03 & -0.20 & -0.02 & 0.03 & 0.01 & -0.07 & -0.07 \\
\hline
\end{tabular}




\begin{tabular}{|c|c|c|c|c|c|c|c|c|c|c|c|}
\hline \multirow[b]{2}{*}{ Behaviour } & \multicolumn{3}{|c|}{ Joint activity } & \multicolumn{3}{|l|}{ Groom } & \multicolumn{2}{|l|}{ Attention } & \multirow[t]{2}{*}{ Proximity } & \multicolumn{2}{|l|}{ Scratch } \\
\hline & Feed & Rest & Travel & Give & Mutual & Receive & present & absent & & Produced & Received \\
\hline & $(0.13)^{* *}$ & $(0.29)$ & $(0.07)$ & $\begin{array}{l}(0.08) \\
* * *\end{array}$ & $(0.10)$ & $(0.12) * * *$ & $(0.22)$ & $(0.37)$ & $(0.42)$ & $(0.12)$ & $(0.13)$ \\
\hline \multicolumn{12}{|l|}{ Object use } \\
\hline No object & $\begin{array}{l}0.03 \\
(0.04)\end{array}$ & $\begin{array}{l}0.10 \\
(0.08)\end{array}$ & $\begin{array}{l}0.47 \\
(0.02)^{* *}\end{array}$ & $\begin{array}{l}0.64 \\
(0.04)^{* *}\end{array}$ & $\begin{array}{l}0.64 \\
(0.04)^{* * *}\end{array}$ & $\begin{array}{l}0.22 \\
(0.03) *\end{array}$ & $\begin{array}{l}0.69 \\
(0.10) * * *\end{array}$ & $\begin{array}{l}0.24 \\
(0.10)^{*}\end{array}$ & $\begin{array}{l}0.56 \\
(0.15)^{* * *}\end{array}$ & $\begin{array}{l}0.40 \\
(0.03)^{*}\end{array}$ & $\begin{array}{l}-0.06 \\
(0.03)\end{array}$ \\
\hline Object & $\begin{array}{l}-0.01 \\
(0.08)\end{array}$ & $\begin{array}{l}-0.08 \\
(0.18)\end{array}$ & $\begin{array}{l}-0.04 \\
(0.04)\end{array}$ & $\begin{array}{l}-0.20 \\
(0.06) * *\end{array}$ & $\begin{array}{l}-0.15 \\
(0.07) * *\end{array}$ & $\begin{array}{l}-0.04 \\
(0.07)\end{array}$ & $\begin{array}{l}-0.18 \\
(0.14) * *\end{array}$ & $\begin{array}{l}-0.10 \\
(0.20)\end{array}$ & $\begin{array}{l}-0.17 \\
(0.26) * *\end{array}$ & $\begin{array}{l}-0.02 \\
(0.07)\end{array}$ & $\begin{array}{l}-0.01 \\
(0.08)\end{array}$ \\
\hline \multicolumn{12}{|l|}{ Multimodal } \\
\hline Unimodal & $\begin{array}{l}0.16 \\
(0.05)\end{array}$ & $\begin{array}{l}0.06 \\
(0.11)\end{array}$ & $\begin{array}{l}0.22 \\
(0.03)^{*}\end{array}$ & $\begin{array}{l}0.75 \\
(0.04) \\
* * *\end{array}$ & $\begin{array}{l}0.27 \\
(0.04)^{*}\end{array}$ & $\begin{array}{l}0.25 \\
(0.04)^{*}\end{array}$ & $\begin{array}{l}0.44 \\
(0.09) \\
* * *\end{array}$ & $\begin{array}{l}0.27 \\
(0.13)^{*}\end{array}$ & $\begin{array}{l}0.44 \\
(0.17)^{* *}\end{array}$ & $\begin{array}{l}0.18 \\
(0.04)^{*}\end{array}$ & $\begin{array}{l}-0.12 \\
(0.05)\end{array}$ \\
\hline $\begin{array}{l}\text { Multimodal } \\
\text { (facial } \\
\text { expression) }\end{array}$ & $\begin{array}{l}-0.13 \\
(0.53)\end{array}$ & $\begin{array}{l}0.06 \\
(1.12)\end{array}$ & $\begin{array}{l}0.30 \\
(0.31)^{*}\end{array}$ & $\begin{array}{l}-0.23 \\
(0.40) * *\end{array}$ & $\begin{array}{l}0.44 \\
(0.47)^{*}\end{array}$ & $\begin{array}{l}0.001 \\
(0.44)\end{array}$ & $\begin{array}{l}0.31 \\
(0.93)^{* * *}\end{array}$ & $\begin{array}{l}-0.04 \\
(1.40)\end{array}$ & $\begin{array}{l}0.14 \\
(1.69)^{*}\end{array}$ & $\begin{array}{l}0.18 \\
(0.49)^{*}\end{array}$ & $\begin{array}{l}0.06 \\
(0.52)\end{array}$ \\
\hline $\begin{array}{l}\text { Multimodal } \\
\text { (vocal) }\end{array}$ & $\begin{array}{l}-0.07 \\
(0.07)\end{array}$ & $\begin{array}{l}-0.06 \\
(0.16)\end{array}$ & $\begin{array}{l}0.01 \\
(0.04)\end{array}$ & $\begin{array}{l}-0.07 \\
(0.05)\end{array}$ & $\begin{array}{l}-0.03 \\
(0.06)\end{array}$ & $\begin{array}{l}-0.09 \\
(0.05) \\
\end{array}$ & $\begin{array}{l}-0.09 \\
(0.12)^{*}\end{array}$ & $\begin{array}{l}-0.08 \\
(0.19)\end{array}$ & $\begin{array}{l}-0.11 \\
(0.23) *\end{array}$ & $\begin{array}{l}0.14 \\
(0.06)\end{array}$ & $\begin{array}{l}0.01 \\
(0.07)\end{array}$ \\
\hline \multicolumn{12}{|l|}{$\begin{array}{l}\text { Repertoire } \\
\text { size }\end{array}$} \\
\hline $\begin{array}{l}\text { Dyadic } \\
\text { repertoire } \\
\text { size }\end{array}$ & $\begin{array}{l}-0.02 \\
(0.04)\end{array}$ & $\begin{array}{l}0.001 \\
(0.10)\end{array}$ & $\begin{array}{l}0.34 \\
(0.03)^{* *}\end{array}$ & $\begin{array}{l}0.26 \\
(0.04)^{*}\end{array}$ & $\begin{array}{l}0.45 \\
(0.05)^{* *}\end{array}$ & $\begin{array}{l}0.14 \\
(0.04)\end{array}$ & $\begin{array}{l}0.42 \\
(0.11)^{* *}\end{array}$ & $\begin{array}{l}0.06 \\
(0.12)\end{array}$ & $\begin{array}{l}0.28 \\
(0.20)^{*}\end{array}$ & $\begin{array}{l}0.35 \\
(0.04)^{*}\end{array}$ & $\begin{array}{l}-0.04 \\
(0.04)\end{array}$ \\
\hline \multicolumn{12}{|l|}{$\begin{array}{l}\text { Combined } \\
\text { gestures }\end{array}$} \\
\hline $\begin{array}{l}\text { Single (non- } \\
\text { combined) }\end{array}$ & $\begin{array}{l}0.02 \\
(0.04)\end{array}$ & $\begin{array}{l}0.06 \\
(0.10)\end{array}$ & $\begin{array}{l}0.09 \\
(0.02)\end{array}$ & $\begin{array}{l}0.64 \\
(0.04)\end{array}$ & $\begin{array}{l}0.19 \\
(0.04)\end{array}$ & $\begin{array}{l}0.08 \\
(0.04)\end{array}$ & $\begin{array}{l}0.29 \\
(0.09)^{* *}\end{array}$ & $\begin{array}{l}0.18 \\
(0.11)^{*}\end{array}$ & $\begin{array}{l}0.29 \\
(0.16)\end{array}$ & $\begin{array}{l}0.26 \\
(0.04) *\end{array}$ & $\begin{array}{l}-0.14 \\
(0.04)\end{array}$ \\
\hline Combined & $\begin{array}{l}0.01 \\
(0.16)\end{array}$ & $\begin{array}{l}-0.03 \\
(0.34)\end{array}$ & $\begin{array}{l}0.41 \\
(0.09) * *\end{array}$ & $\begin{array}{l}-0.19 \\
(0.12)^{*}\end{array}$ & $\begin{array}{l}0.40 \\
(0.16)^{* *}\end{array}$ & $\begin{array}{l}0.13 \\
(0.15)\end{array}$ & $\begin{array}{l}0.30 \\
(0.30)^{* *}\end{array}$ & $\begin{array}{l}-0.03 \\
(0.42)\end{array}$ & $\begin{array}{l}0.15 \\
(0.58) * *\end{array}$ & $\begin{array}{l}0.15 \\
(0.15)\end{array}$ & $\begin{array}{l}0.09 \\
(0.16)\end{array}$ \\
\hline \multicolumn{12}{|l|}{ Attention } \\
\hline Mutual & -0.04 & 0.10 & 0.12 & 0.78 & -0.01 & 0.02 & 0.12 & 0.29 & 0.30 & -0.03 & -0.13 \\
\hline
\end{tabular}




\begin{tabular}{|c|c|c|c|c|c|c|c|c|c|c|c|}
\hline \multirow[b]{2}{*}{ Behaviour } & \multicolumn{3}{|c|}{ Joint activity } & \multicolumn{3}{|l|}{ Groom } & \multicolumn{2}{|l|}{ Attention } & \multirow[t]{2}{*}{ Proximity } & \multicolumn{2}{|l|}{ Scratch } \\
\hline & Feed & Rest & Travel & Give & Mutual & Receive & present & absent & & Produced & Received \\
\hline $\begin{array}{l}\text { attention } \\
\text { absent }\end{array}$ & $(0.08)$ & $(0.19)$ & $(0.04)$ & $\begin{array}{l}(0.07) \\
* * *\end{array}$ & $(0.06)$ & $(0.06)$ & $(0.13)$ & $(0.20)^{*}$ & $(0.24)^{* *}$ & $(0.07)$ & $(0.08)^{*}$ \\
\hline $\begin{array}{l}\text { Mutual } \\
\text { attention } \\
\text { present }\end{array}$ & $\begin{array}{l}0.05 \\
(0.06)\end{array}$ & $\begin{array}{l}0.004 \\
(0.16)\end{array}$ & $\begin{array}{l}0.37 \\
(0.04)^{* *}\end{array}$ & $\begin{array}{l}-0.11 \\
(0.04)^{*}\end{array}$ & $\begin{array}{l}0.63(0.07 \\
) * *\end{array}$ & $\begin{array}{l}0.21 \\
(0.06)\end{array}$ & $\begin{array}{l}0.56 \\
(0.14) * * *\end{array}$ & $\begin{array}{l}-0.03 \\
(0.17)\end{array}$ & $\begin{array}{l}0.26 \\
(0.26)^{*}\end{array}$ & $\begin{array}{l}0.53 \\
(0.06)^{*}\end{array}$ & $\begin{array}{l}0.05 \\
(0.06)\end{array}$ \\
\hline \multicolumn{12}{|l|}{$\begin{array}{l}\text { Bodily and } \\
\text { manual }\end{array}$} \\
\hline Bodily & $\begin{array}{l}0.067 \\
(0.04)\end{array}$ & $\begin{array}{l}0.06 \\
(0.09)\end{array}$ & $\begin{array}{l}0.50 \\
(0.03) *\end{array}$ & $\begin{array}{l}0.22 \\
(0.03)^{*}\end{array}$ & $\begin{array}{l}0.58 \\
(0.04)^{* *}\end{array}$ & $\begin{array}{l}0.25 \\
(0.04) *\end{array}$ & $\begin{array}{l}0.55 \\
(0.09) * * *\end{array}$ & $\begin{array}{l}0.14 \\
(0.12)\end{array}$ & $\begin{array}{l}0.41 \\
(0.16) *\end{array}$ & $\begin{array}{l}0.55 \\
(0.04)^{*}\end{array}$ & $\begin{array}{l}-0.02 \\
(0.04)\end{array}$ \\
\hline Manual & $\begin{array}{l}-0.08 \\
(0.09)\end{array}$ & $\begin{array}{l}-0.01 \\
(0.19)\end{array}$ & $\begin{array}{l}-0.06 \\
(0.05)\end{array}$ & $\begin{array}{l}0.29 \\
(0.07)^{*}\end{array}$ & $\begin{array}{l}-0.07 \\
(0.08)\end{array}$ & $\begin{array}{l}-0.09 \\
(0.08)\end{array}$ & $\begin{array}{l}-0.02 \\
(0.15)\end{array}$ & $\begin{array}{l}0.03 \\
(0.23)\end{array}$ & $\begin{array}{l}0.01 \\
(0.31)\end{array}$ & $\begin{array}{l}-0.18 \\
(0.08) *\end{array}$ & $\begin{array}{l}-0.06 \\
(0.08)\end{array}$ \\
\hline \multicolumn{12}{|l|}{ Events } \\
\hline Events & $\begin{array}{l}-0.01 \\
(0.03)\end{array}$ & $\begin{array}{l}0.04 \\
(0.07)\end{array}$ & $\begin{array}{l}0.40 \\
(0.02)^{*}\end{array}$ & $\begin{array}{l}0.47 \\
(0.03)^{*}\end{array}$ & $\begin{array}{l}0.45 \\
(0.03) *\end{array}$ & $\begin{array}{l}0.16 \\
(0.02) \\
\end{array}$ & $\begin{array}{l}0.47 \\
(0.07)^{* * *}\end{array}$ & $\begin{array}{l}0.15 \\
(0.08) *\end{array}$ & $\begin{array}{l}0.37 \\
(0.12)^{*}\end{array}$ & $\begin{array}{l}0.36 \\
(0.03) *\end{array}$ & $\begin{array}{l}-0.07 \\
(0.03)\end{array}$ \\
\hline \multicolumn{12}{|l|}{ Indicative } \\
\hline $\begin{array}{l}\text { Manual } \\
\text { indicative }\end{array}$ & $\begin{array}{l}0.09 \\
(0.41)\end{array}$ & $\begin{array}{l}0.05 \\
(1.03)\end{array}$ & $\begin{array}{l}0.43 \\
(0.28)^{*}\end{array}$ & $\begin{array}{l}0.17 \\
(0.36)^{*}\end{array}$ & $\begin{array}{l}0.56 \\
(0.46) * * *\end{array}$ & $\begin{array}{l}0.17 \\
(0.38) *\end{array}$ & $\begin{array}{l}0.54 \\
(0.95) * * *\end{array}$ & $\begin{array}{l}0.09 \\
(1.11)\end{array}$ & $\begin{array}{l}0.37 \\
(1.76) *\end{array}$ & $\begin{array}{l}0.40 \\
(0.43) *\end{array}$ & $\begin{array}{l}0.01 \\
(0.41)\end{array}$ \\
\hline $\begin{array}{l}\text { Manual non- } \\
\text { indicative }\end{array}$ & $\begin{array}{l}-0.08 \\
(0.07)\end{array}$ & $\begin{array}{l}0.01 \\
(0.18)\end{array}$ & $\begin{array}{l}0.04 \\
(0.05)\end{array}$ & $\begin{array}{l}0.35 \\
(0.06) *\end{array}$ & $\begin{array}{l}0.02 \\
(0.07)\end{array}$ & $\begin{array}{l}-0.02 \\
(0.07)\end{array}$ & $\begin{array}{l}0.06 \\
(0.14)\end{array}$ & $\begin{array}{l}0.07 \\
(0.21)\end{array}$ & $\begin{array}{l}0.08 \\
(0.29)\end{array}$ & $\begin{array}{l}-0.05 \\
(0.07)\end{array}$ & $\begin{array}{l}-0.07 \\
(0.08)\end{array}$ \\
\hline \multicolumn{12}{|l|}{ Proximity } \\
\hline Close & $\begin{array}{l}0.05 \\
(0.05)\end{array}$ & $\begin{array}{l}0.12 \\
(0.12)^{*}\end{array}$ & $\begin{array}{l}0.27 \\
(0.03)^{*}\end{array}$ & $\begin{array}{l}0.76 \\
(0.05) * * *\end{array}$ & $\begin{array}{l}0.39 \\
(0.05)^{*}\end{array}$ & $\begin{array}{l}0.15 \\
(0.04)\end{array}$ & $\begin{array}{l}0.50 \\
(0.12)^{*}\end{array}$ & $\begin{array}{l}0.29 \\
(0.15)^{*}\end{array}$ & $\begin{array}{l}0.48 \\
(0.21)^{* * * *}\end{array}$ & $\begin{array}{l}0.21 \\
(0.05)^{*}\end{array}$ & $\begin{array}{l}-0.11 \\
(0.05) *\end{array}$ \\
\hline Far & $\begin{array}{l}-0.06 \\
(0.04)\end{array}$ & $\begin{array}{l}-0.05 \\
(0.11)\end{array}$ & $\begin{array}{l}0.22 \\
(0.03)^{*}\end{array}$ & $\begin{array}{l}-0.11 \\
(0.03)^{*}\end{array}$ & $\begin{array}{l}0.22 \\
(0.04) *\end{array}$ & $\begin{array}{l}0.05 \\
(0.04) \\
\end{array}$ & $\begin{array}{l}0.13 \\
(0.09) *\end{array}$ & $\begin{array}{l}-0.07 \\
(0.12)\end{array}$ & $\begin{array}{l}0.03 \\
(0.15)\end{array}$ & $\begin{array}{l}0.24 \\
(0.04)^{*}\end{array}$ & $\begin{array}{l}0.01 \\
(0.05)\end{array}$ \\
\hline \multicolumn{12}{|l|}{ Repetitive } \\
\hline $\begin{array}{l}\text { Non- } \\
\text { repetitive }\end{array}$ & $\begin{array}{l}-0.07 \\
(0.05)\end{array}$ & $\begin{array}{l}0.03 \\
(0.10)\end{array}$ & $\begin{array}{l}0.56 \\
(0.03) *\end{array}$ & $\begin{array}{l}-0.06 \\
(0.04)\end{array}$ & $\begin{array}{l}0.73 \\
(0.05) * * *\end{array}$ & $\begin{array}{l}0.21 \\
(0.04)^{*}\end{array}$ & $\begin{array}{l}0.57 \\
(0.10)^{*}\end{array}$ & $\begin{array}{l}0.03 \\
(1.36)\end{array}$ & $\begin{array}{l}0.33 \\
(0.18)^{*}\end{array}$ & $\begin{array}{l}0.42 \\
(0.042)^{*}\end{array}$ & $\begin{array}{l}0.05 \\
(0.05)\end{array}$ \\
\hline Repetitive & $\begin{array}{l}0.09 \\
(0.05)\end{array}$ & $\begin{array}{l}0.02 \\
(0.13)\end{array}$ & $\begin{array}{l}-0.09 \\
(0.03)\end{array}$ & $\begin{array}{l}0.61 \\
(0.05) * * *\end{array}$ & $\begin{array}{l}-0.19 \\
(0.04) *\end{array}$ & $\begin{array}{l}-0.04 \\
(0.04)\end{array}$ & $\begin{array}{l}-0.01 \\
(0.09)\end{array}$ & $\begin{array}{l}0.01 \\
(0.13)\end{array}$ & $\begin{array}{l}0.11 \\
(0.19)\end{array}$ & $\begin{array}{l}-0.01 \\
(0.05)\end{array}$ & $\begin{array}{l}-0.14 \\
(0.05) *\end{array}$ \\
\hline
\end{tabular}




\begin{tabular}{|c|c|c|c|c|c|c|c|c|c|c|c|}
\hline \multirow[b]{2}{*}{ Behaviour } & \multicolumn{3}{|c|}{ Joint activity } & \multicolumn{3}{|l|}{ Groom } & \multicolumn{2}{|l|}{ Attention } & \multirow[t]{2}{*}{ Proximity } & \multicolumn{2}{|l|}{ Scratch } \\
\hline & Feed & Rest & Travel & Give & Mutual & Receive & present & absent & & Produced & Received \\
\hline \multicolumn{12}{|l|}{ Homogeneity } \\
\hline $\begin{array}{l}\text { Heterogeneo } \\
\text { us }\end{array}$ & $\begin{array}{l}0.01 \\
(0.08)\end{array}$ & $\begin{array}{l}-0.02 \\
(0.20)\end{array}$ & $\begin{array}{l}-0.03 \\
(0.05)\end{array}$ & $\begin{array}{l}0.11 \\
(0.07)\end{array}$ & $\begin{array}{l}-0.15 \\
(0.08) *\end{array}$ & $\begin{array}{l}-0.01 \\
(0.08)\end{array}$ & $\begin{array}{l}-0.09 \\
(0.15)^{*}\end{array}$ & $\begin{array}{l}0.04 \\
(0.23)\end{array}$ & $\begin{array}{l}-0.03 \\
(0.30)\end{array}$ & $\begin{array}{l}0.05 \\
(0.08)\end{array}$ & $\begin{array}{l}-0.03 \\
(0.09)\end{array}$ \\
\hline $\begin{array}{l}\text { Homogeneou } \\
\mathrm{s}\end{array}$ & $\begin{array}{l}-0.01 \\
(0.04)\end{array}$ & $\begin{array}{l}0.08 \\
(0.11)\end{array}$ & $\begin{array}{l}0.43 \\
(0.03)^{*}\end{array}$ & $\begin{array}{l}0.52 \\
(0.04)^{*}\end{array}$ & $\begin{array}{l}0.60 \\
(0.05) * * *\end{array}$ & $\begin{array}{l}0.17 \\
(0.04)^{*}\end{array}$ & $\begin{array}{l}0.60 \\
(0.10)^{* *}\end{array}$ & $\begin{array}{l}0.17 \\
(0.12)^{*}\end{array}$ & $\begin{array}{l}0.45 \\
(0.18) * * *\end{array}$ & $\begin{array}{l}0.38 \\
(0.042)^{*}\end{array}$ & $\begin{array}{l}-0.08 \\
(0.04)\end{array}$ \\
\hline \multicolumn{12}{|l|}{ Sequences } \\
\hline $\begin{array}{l}\text { Single (no } \\
\text { sequence) }\end{array}$ & $\begin{array}{l}0.08 \\
(0.06)\end{array}$ & $\begin{array}{l}0.08 \\
(0.15)\end{array}$ & $\begin{array}{l}0.22 \\
(0.04)^{*}\end{array}$ & $\begin{array}{l}0.66 \\
(0.06) * *\end{array}$ & $\begin{array}{l}0.33 \\
(0.06)^{*}\end{array}$ & $\begin{array}{l}0.16 \\
(0.05)\end{array}$ & \begin{tabular}{|l}
0.47 \\
$(0.13)^{*}$
\end{tabular} & $\begin{array}{l}0.23 \\
(0.17)^{*}\end{array}$ & $\begin{array}{l}0.42 \\
(0.25) * * *\end{array}$ & $\begin{array}{l}0.08 \\
(0.05)\end{array}$ & $\begin{array}{l}-0.14 \\
(0.06) *\end{array}$ \\
\hline $\begin{array}{l}\text { Rapid } \\
\text { sequence }\end{array}$ & \begin{tabular}{|l|}
-0.06 \\
$(0.19)$ \\
\end{tabular} & $\begin{array}{l}-0.03 \\
(0.47) \\
\end{array}$ & $\begin{array}{l}0.20 \\
(0.11)^{*}\end{array}$ & $\begin{array}{l}0.03 \\
(0.13) \\
\end{array}$ & $\begin{array}{l}0.16 \\
(0.17)^{*}\end{array}$ & $\begin{array}{l}0.01 \\
(0.16)\end{array}$ & $\begin{array}{l}0.09 \\
(0.36) \\
\end{array}$ & $\begin{array}{l}-0.01 \\
(0.48)\end{array}$ & $\begin{array}{l}0.04 \\
(0.65) \\
\end{array}$ & $\begin{array}{l}-0.02 \\
(0.15)\end{array}$ & $\begin{array}{l}0.01 \\
(0.19)\end{array}$ \\
\hline Persistence & \begin{tabular}{|l|}
-0.03 \\
$(0.53)$
\end{tabular} & $\begin{array}{l}0.03 \\
(1.25)\end{array}$ & $\begin{array}{l}0.14 \\
(0.29)^{*}\end{array}$ & $\begin{array}{l}-0.05 \\
(0.38)\end{array}$ & $\begin{array}{l}0.16 \\
(0.48)^{*}\end{array}$ & $\begin{array}{l}0.05 \\
(0.46) \\
\end{array}$ & \begin{tabular}{|l|}
0.09 \\
$(1.04)$
\end{tabular} & $\begin{array}{l}0.02 \\
(1.49)\end{array}$ & $\begin{array}{l}0.06 \\
(1.86)\end{array}$ & $\begin{array}{l}0.57 \\
(0.50)^{* * *}\end{array}$ & $\begin{array}{l}0.06 \\
(0.51)\end{array}$ \\
\hline \multicolumn{12}{|l|}{$\begin{array}{l}\text { Penile } \\
\text { erection }\end{array}$} \\
\hline $\begin{array}{l}\text { Penile } \\
\text { erection }\end{array}$ & \begin{tabular}{|l|}
0.04 \\
$(0.22)$
\end{tabular} & $\begin{array}{l}-0.01 \\
(0.49)\end{array}$ & $\begin{array}{l}0.07 \\
(0.14)\end{array}$ & $\begin{array}{l}0.02 \\
(0.20)\end{array}$ & $\begin{array}{l}-0.04 \\
(0.23)\end{array}$ & $\begin{array}{l}-0.04 \\
(0.21) \\
\end{array}$ & $\begin{array}{l}-0.01 \\
(0.47) \\
\end{array}$ & $\begin{array}{l}-0.01 \\
(0.62)\end{array}$ & $\begin{array}{l}-0.01 \\
(0.80)\end{array}$ & $\begin{array}{l}0.10 \\
(0.22)\end{array}$ & $\begin{array}{l}0.01 \\
(0.23)\end{array}$ \\
\hline \multicolumn{12}{|l|}{ Piloerection } \\
\hline Piloerection & $\begin{array}{l}-0.04 \\
(0.04)\end{array}$ & $\begin{array}{l}-0.02 \\
(0.10)\end{array}$ & $\begin{array}{l}0.38 \\
(0.03)^{*}\end{array}$ & $\begin{array}{l}0.09 \\
(0.04)\end{array}$ & $\begin{array}{l}0.42 \\
(0.04)^{*}\end{array}$ & $\begin{array}{l}0.14 \\
(0.04)\end{array}$ & $\begin{array}{l}0.35 \\
(0.10)^{*}\end{array}$ & $\begin{array}{l}0.02 \\
(0.13)\end{array}$ & $\begin{array}{l}0.21 \\
(0.17)^{*}\end{array}$ & $\begin{array}{l}0.24 \\
(0.04)^{*}\end{array}$ & $\begin{array}{l}-0.05 \\
(0.04)\end{array}$ \\
\hline \multicolumn{12}{|l|}{$\begin{array}{l}\text { Gesture } \\
\text { function }\end{array}$} \\
\hline Copulation & $0.05(0.31)$ & $0.01(0.84)$ & $0.05(0.18)$ & $\begin{array}{l}-0.01 \\
(0.21)\end{array}$ & $0.01(0.25)$ & $\begin{array}{l}-0.02 \\
(0.24) \\
\end{array}$ & $0.02(0.53)$ & $0.01(0.84)$ & $0.02(0.99)$ & $0.12(0.27)$ & $0.03(0.34)$ \\
\hline Food sharing & $0.1(8.36)$ & $\begin{array}{l}0.01 \\
(23.98)\end{array}$ & $\begin{array}{l}-0.01 \\
(5.05)\end{array}$ & $\begin{array}{l}-0.01 \\
(6.39)\end{array}$ & $\begin{array}{l}-0.02 \\
(9.54)\end{array}$ & $\begin{array}{l}-0.01 \\
(6.74) \\
\end{array}$ & $0.01(16.6)$ & $0.09(26.6)$ & $\begin{array}{l}0.07 \\
(29.25)\end{array}$ & $\begin{array}{l}-0.02 \\
(7.31)\end{array}$ & $\begin{array}{l}-0.07 \\
(11.31)\end{array}$ \\
\hline $\begin{array}{l}\text { Threat to } \\
\text { dominate }\end{array}$ & $\begin{array}{l}-0.5 \\
(1.64)^{*}\end{array}$ & $-0.2(3.57)$ & $0.03(1.1)$ & $-0.2(1.17)$ & $\begin{array}{l}-0.65 \\
(1.45)^{* *}\end{array}$ & $0.04(1.29)$ & $\begin{array}{l}-0.64 \\
(2.91)^{* *}\end{array}$ & $0.1(4.63)$ & $-0.29(5.5)$ & $0.19(1.42)$ & $0.01(1.88)$ \\
\hline Give groom & $\begin{array}{l}0.17 \\
(0.13)^{*}\end{array}$ & $0.11(0.31)$ & $0.05(0.07)$ & $\begin{array}{l}0.69 \\
(0.12)^{* * *}\end{array}$ & $0.03(0.11)$ & $0.01(0.1)$ & $\begin{array}{l}0.25 \\
(0.26)^{*}\end{array}$ & $\begin{array}{l}0.24 \\
(0.37)^{*}\end{array}$ & $\begin{array}{l}0.3 \\
(0.47)^{* *}\end{array}$ & $0.1(0.11)$ & $\begin{array}{l}-0.15 \\
(0.15)^{*}\end{array}$ \\
\hline
\end{tabular}




\begin{tabular}{|c|c|c|c|c|c|c|c|c|c|c|c|}
\hline \multirow[b]{2}{*}{ Behaviour } & \multicolumn{3}{|c|}{ Joint activity } & \multicolumn{3}{|l|}{ Groom } & \multicolumn{2}{|l|}{ Attention } & \multirow[t]{2}{*}{ Proximity } & \multicolumn{2}{|l|}{ Scratch } \\
\hline & Feed & Rest & Travel & Give & Mutual & Receive & present & absent & & Produced & Received \\
\hline $\begin{array}{l}\text { Mutually } \\
\text { groom }\end{array}$ & $0.66(2.39)$ & $0.1(6.48)$ & $0.03(1.42)$ & $-0.1(1.45)$ & $\begin{array}{l}1.14 \\
(1.97)^{*}\end{array}$ & $\begin{array}{l}-0.52 \\
(2.01)\end{array}$ & $\begin{array}{l}0.79 \\
(3.97)^{*}\end{array}$ & $-0.1(6.45)$ & $0.38(8.36)$ & $0.48(2.05)$ & $0.2(2.67)$ \\
\hline Receive groom & $\begin{array}{l}0.47 \\
(0.55)^{*}\end{array}$ & $0.08(1.44)$ & $0.08(0.32)$ & $0.2(0.33)^{*}$ & $\begin{array}{l}0.53 \\
(0.48)^{* *}\end{array}$ & $\begin{array}{l}0.9 \\
(0.53)^{* *}\end{array}$ & $\begin{array}{l}0.51 \\
(0.96)^{* *}\end{array}$ & $\begin{array}{l}0.38 \\
(1.55)^{*}\end{array}$ & $\begin{array}{l}0.55 \\
(1.95)^{* *}\end{array}$ & $\begin{array}{l}-0.12 \\
(0.46)\end{array}$ & $0.1(0.6)$ \\
\hline Reassurance & $\begin{array}{l}-0.59 \\
(1.87) \\
\end{array}$ & $0.03(4.55)$ & $0.37(1.02)$ & $0.2(1.08)$ & $\begin{array}{l}-0.25 \\
(1.47) \\
\end{array}$ & $\begin{array}{l}-0.04 \\
(1.37) \\
\end{array}$ & $-0.02(3.1)$ & $\begin{array}{l}-0.29 \\
(5.47)\end{array}$ & $\begin{array}{l}-0.21 \\
(6.33) \\
\end{array}$ & $-0.2(1.54)$ & $\begin{array}{l}-0.35 \\
(2.01)\end{array}$ \\
\hline Other threat & $\begin{array}{l}-0.02 \\
(0.71)\end{array}$ & $\begin{array}{l}-0.03 \\
(1.75)\end{array}$ & $\begin{array}{l}-0.05 \\
(0.39)\end{array}$ & $\begin{array}{l}-0.06 \\
(0.47)^{*}\end{array}$ & $\begin{array}{l}-0.03 \\
(0.58)\end{array}$ & $0.02(0.53)$ & $\begin{array}{l}-0.01 \\
(1.16)\end{array}$ & $\begin{array}{l}-0.05 \\
(2.13)\end{array}$ & $\begin{array}{l}-0.03 \\
(2.35)\end{array}$ & $\begin{array}{l}0.48 \\
(0.65)^{* *}\end{array}$ & $0.02(0.71)$ \\
\hline $\begin{array}{l}\text { Synchronized } \\
\text { high-intensity } \\
\text { panthoot }\end{array}$ & $\begin{array}{l}-0.08 \\
(0.29)\end{array}$ & $\begin{array}{l}-0.07 \\
(0.66)\end{array}$ & $\begin{array}{l}-0.06 \\
(0.14)\end{array}$ & $0.03(0.18)$ & $0.01(0.27)$ & $-0.02(0.2)$ & $\begin{array}{l}-0.07 \\
(0.48)\end{array}$ & $\begin{array}{l}-0.09 \\
(0.72)^{*}\end{array}$ & $\begin{array}{l}-0.1 \\
(0.89)^{*}\end{array}$ & $\begin{array}{l}-0.04 \\
(0.23)\end{array}$ & $\begin{array}{l}-0.13 \\
(0.31)^{*}\end{array}$ \\
\hline $\begin{array}{l}\text { Solo high- } \\
\text { intensity } \\
\text { panthoot }\end{array}$ & $0.02(0.53)$ & $\begin{array}{l}-0.01 \\
(1.34)\end{array}$ & $0.1(0.3)$ & $0(0.34)$ & $0.01(0.4)$ & $\begin{array}{l}-0.01 \\
(0.41)\end{array}$ & $0.03(0.89)$ & $0.01(1.47)$ & $0.03(1.7)$ & $\begin{array}{l}-0.04 \\
(0.45)\end{array}$ & $0.05(0.52)$ \\
\hline $\begin{array}{l}\text { Synchronized } \\
\text { low-intensity } \\
\text { panthoot }\end{array}$ & $\begin{array}{l}0.14 \\
(0.69)^{*}\end{array}$ & $0.05(2)$ & $\begin{array}{l}0.26 \\
(0.45)^{*}\end{array}$ & $\begin{array}{l}-0.04 \\
(0.44)\end{array}$ & $0.05(0.58)$ & $-0.01(0.6)$ & $0.1(1.25)^{*}$ & $\begin{array}{l}0.13 \\
(2.06)^{*}\end{array}$ & $\begin{array}{l}0.14 \\
(2.59)^{*}\end{array}$ & $0.11(0.59)$ & $0.09(0.67)$ \\
\hline Play & $\begin{array}{l}-0.19 \\
(0.13)^{* *}\end{array}$ & $\begin{array}{l}-0.04 \\
(0.27) \\
\end{array}$ & $\begin{array}{l}-0.03 \\
(0.07)\end{array}$ & $\begin{array}{l}0.19 \\
(0.09)^{*}\end{array}$ & $-0.1(0.1)^{*}$ & $\begin{array}{l}-0.2 \\
(0.1)^{* *}\end{array}$ & $\begin{array}{l}-0.09 \\
(0.24)^{*}\end{array}$ & $\begin{array}{l}-0.04 \\
(0.33) \\
\end{array}$ & $\begin{array}{l}-0.08 \\
(0.4)^{*}\end{array}$ & $\begin{array}{l}-0.05 \\
(0.11)\end{array}$ & $\begin{array}{l}-0.05 \\
(0.14) \\
\end{array}$ \\
\hline Greeting & $-0.11(0.3)$ & $0.04(0.75)$ & $0.01(0.17)$ & $\begin{array}{l}0.11 \\
(0.19)^{*}\end{array}$ & $\begin{array}{l}-0.05 \\
(0.21)\end{array}$ & $\begin{array}{l}-0.08 \\
(0.25)^{*}\end{array}$ & $-0.02(0.6)$ & $0.04(0.9)$ & $0.01(1.08)$ & $0.07(0.25)$ & $0.08(0.35)$ \\
\hline Travel & $0.05(0.81)$ & $0.03(1.73)$ & $0.1(0.44)^{*}$ & $0.1(0.54)^{*}$ & $0.01(0.73)$ & $0.02(0.55)$ & $0.04(1.33)$ & $0.06(2.13)$ & $0.06(2.56)$ & $-0.04(0.6)$ & $0.01(0.83)$ \\
\hline
\end{tabular}

